\title{
Introduction to the European Monitoring and Evaluation Programme (EMEP) and observed atmospheric composition change during 1972-2009
}

\author{
K. Tørseth, W. Aas, K. Breivik, A. M. Fjæraa, M. Fiebig, A. G. Hjellbrekke, C. Lund Myhre, S. Solberg, and \\ K. E. Yttri \\ NILU - Norwegian Institute for Air Research, P.O. Box 100, 2027 Kjeller, Norway
}

Correspondence to: K. Tørseth (kt@nilu.no)

Received: 31 December 2011 - Published in Atmos. Chem. Phys. Discuss.: 19 January 2012

Revised: 16 May 2012 - Accepted: 3 June 2012 - Published: 22 June 2012

\begin{abstract}
European scale harmonized monitoring of atmospheric composition was initiated in the early 1970s, and the activity has generated a comprehensive dataset (available at http://www.emep.int) which allows the evaluation of regional and spatial trends of air pollution during a period of nearly $40 \mathrm{yr}$. Results from the monitoring made within EMEP, the European Monitoring and Evaluation Programme, show large reductions in ambient concentrations and deposition of sulphur species during the last decades. Reductions are in the order of 70-90\% since the year 1980, and correspond well with reported emission changes. Also reduction in emissions of nitrogen oxides $\left(\mathrm{NO}_{\mathrm{x}}\right)$ are reflected in the measurements, with an average decrease of nitrogen dioxide and nitrate in precipitation by about $23 \%$ and $25 \%$ respectively since 1990 . Only minor reductions are however seen since the late 1990s. The concentrations of total nitrate in air have decreased on average only by $8 \%$ since 1990, and fewer sites show a significant trend. A majority of the EMEP sites show a decreasing trend in reduced nitrogen both in air and precipitation on the order of $25 \%$ since 1990 . Deposition of base cations has decreased during the past $30 \mathrm{yr}$, and the $\mathrm{pH}$ in precipitation has increased across Europe. Large inter annual variations in the particulate matter mass concentrations reflect meteorological variability, but still there is a relatively clear overall decrease at several sites during the last decade. With few observations going back to the 1990s, the observed chemical composition is applied to document a change in particulate matter (PM) mass even since 1980. These data indicate an overall reduction of about $5 \mu \mathrm{g} \mathrm{m}^{-3}$ from sulphate alone. Despite the significant reductions in sul-
\end{abstract}

phur emissions, sulphate still remains one of the single most important compounds contributing to regional scale aerosol mass concentration. Long-term ozone trends at EMEP sites show a mixed pattern. The year-to-year variability in ozone due to varying meteorological conditions is substantial, making it hard to separate the trends caused by emission change from other effects. For the Nordic countries the data indicate a reduced occurrence of very low concentrations. The most pronounced change in the frequency distribution is seen at sites in the UK and the Netherlands, showing a reduction in the higher values. Smaller changes are seen in Germany, while in Switzerland and Austria, no change is seen in the frequency distribution of ozone. The lack of long-term data series is a major obstacle for studying trends in volatile organic compounds (VOC). The scatter in the data is large, and significant changes are only found for certain components and stations. Concentrations of the heavy metals lead and cadmium have decreased in both air and precipitation during the last $20 \mathrm{yr}$, with reductions in the order of $80-90 \%$ for $\mathrm{Pb}$ and $64-84 \%$ for $\mathrm{Cd}$ (precipitation and air respectively). The measurements of total gaseous mercury indicate a dramatic decrease in concentrations during 1980 to about 1993. Trends in hexachlorocyclohexanes (HCHs) show a significant decrease in annual average air concentrations. For other persistent organic pollutants (POPs) the patterns is mixed, and differs between sites and between measurements in air versus precipitation. 


\section{Introduction}

A European network of monitoring sites to quantify input of nutrients to agricultural areas was established in 1947 (Egner et al., 1955; Rohde and Granat, 1984). Swedish scientists later discovered that the observed acidity in precipitation gradually increased and posed the hypothesis that anthropogenic emissions of sulphur could adversely impact natural ecosystems even distant from source regions (Odèn, 1968). This formed the basis for a coordinated research effort during the period 1972-1977 to study long range transport of air pollutants. The activity was coordinated through a project funded by the Organisation for Economic Cooperation and Development (OECD, 1977). A new measurement station network was established and, combined with emissions inventories (Semb, 1978) and model calculations (Eliassen, 1978), transboundary fluxes of acidifying pollutants were proven to be significant. Political consensus was reached on the need for an international coordinated action and this subsequently led to the establishment of the Convention on Long Range Transboundary Air Pollution (CLRTAP) in 1979. The network of monitoring sites established for the OECD project was later continued under the European Monitoring and Evaluation Programme (EMEP), and the program itself was extended to include a wide range of substances which are subject to atmospheric transport across national boundaries.

The main objective of EMEP is to provide governments with information of the deposition and concentration of air pollutants, as well as the quantity and significance of the long-range transmission of air pollutants and their fluxes across boundaries (UNECE, 2004a). The EMEP observations include measurements of species linked to acidification, eutrophication, photochemical oxidants, heavy metals, persistent organic pollutants, and particulate matter. Most of the substances included in the EMEP monitoring program are also fundamental for improving the knowledge of climate change and both local and urban air quality. Obviously, the measurements need to be made in a comparable way at all sites and consistent in time to allow the assessment of temporal and spatial trends. The Chemical Coordinating Centre EMEP (EMEP-CCC) was established at NILU (Norwegian Institute for Air Research) in 1977 to harmonize these efforts. An overview of the development of the main EMEP measurement program is illustrated in Fig. 1. The measurements are widely used by the scientific community, and have served as a basis for an extensive number of scientific studies during nearly $40 \mathrm{yr}$. A major objective of this paper is thus to present and document the EMEP observation network and how it serves as a lead programme for addressing air quality, atmospheric composition change and transboundary fluxes of harmful substances.

The monitoring activity is supplemented with development of emission inventories, modelling of atmospheric chemistry transport and deposition, and with integrated as- sessment modelling including projections to develop cost efficient measures. This supports legally binding protocols aiming to reduce environmental impacts on ecosystems, human health and materials. The EMEP protocol (one of the eight protocols under CLRTAP, see Fig. 1) specifies commitments of its parties including the funding of technical centres which support the activities defined by the workplan. Parties are further obliged to implement the monitoring program as defined by the EMEP monitoring strategy (UNECE, 2009). An introduction to the history and the activities undertaken by CLRTAP can be found in UNECE (2004b). The monitoring concept established by EMEP is similar to what is serving similar monitoring efforts outside the European region, including North America (NADP, IMPROVE, CAPMoN and others), South East Asia (EANET), Africa (Debits) and South Asia (Male Declaration) (Tørseth, 2008). These regional programs are contributing to the WMO Global Atmosphere Watch (GAW) programme. In December 2004, the EMEP Task Force on Hemispheric Transport of Air Pollution (TF HTAP) was established as a response to the increasing scientific evidence of the importance of intercontinental transport of air pollutants. Since its first meeting in June 2005, the TF HTAP has organized a series of projects and collaborative model experiments designed to advance the state-of-science related to the intercontinental transport of ozone, particulate matter, mercury, and persistent organic pollutants (HTAP, 2010).

Since EMEP was established, knowledge about air pollution has greatly increased, and as a result of legislation, economical and technological changes, emission source distribution and source strengths have undergone significant changes. Independent measurements are still required to assess atmospheric pollution in general and the effect of abatement measures in particular. In addition to monitoring trends, information on atmospheric processes is of key importance to validate and further develop models (e.g. Simpson et al., 2012; Travnikov et al., 2012). Certain EMEP sites operating advanced instrumentation have documented their importance as a distributed research infrastructure and have thereby qualified for support from the EC and from national research councils. Examples of such infrastructures projects include the European Supersites for Atmospheric Aerosol Research (EUSAAR) addressing aerosols (Philippin et al., 2009), the Aerosols, Clouds, and Trace gases Research InfraStructure Network (ACTRIS) addressing aerosols and reactive gases (http://www.actris.net), and the Integrated non- $\mathrm{CO}_{2}$ Greenhouse Gas Observing System (InGOS) for non- $\mathrm{CO}_{2}$ greenhouse gases (http://www.ingos-infrastructure.eu/). In these EU-projects, support is given to improve methodologies and support access to sites and distribution of data to broad user communities. This is an important link to scientific communities and contributes to further development of the EMEP program. The basic monitoring however is founded in obligations to the international conventions CLRTAP/EMEP and WMO-GAW, and relies on national funding. 


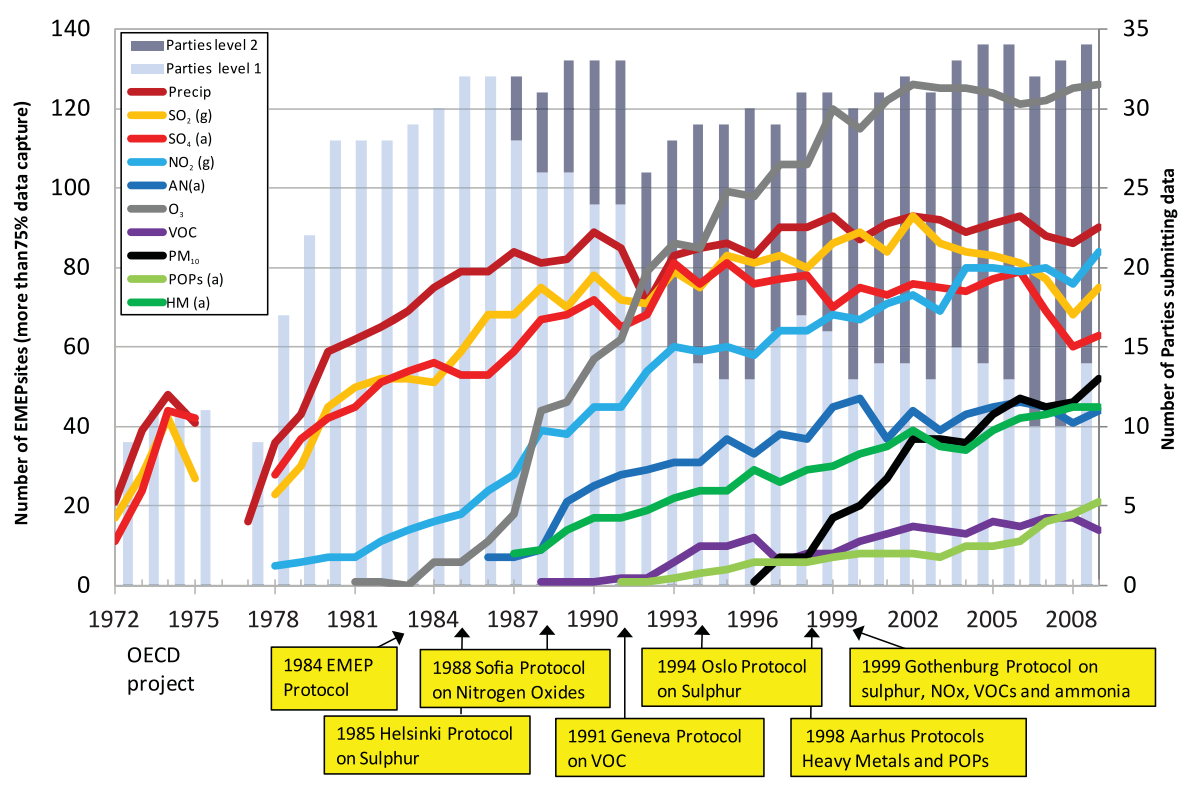

Fig. 1. Development of the measurement programme. Bars represent the number of parties/countries submitting data according to the level-1 and level-2 monitoring requirements, respectively. Lines indicate the number of sites for which measurements of the various variables have been measured $(\mathrm{g})=$ gaseous, $(\mathrm{a})=$ aerosol, $\mathrm{AN}=\mathrm{NH}_{3}+\mathrm{NH}_{4}^{+}$and/or $\mathrm{HNO}_{3}+\mathrm{NO}_{3}^{-}$.

This paper gives an overview of the monitoring within EMEP and presents main findings from the program. Results are presented and discussed in the following chapters according to the themes addressed by CLRTAP. We document the main development of the monitoring program with focus on selected spatial and temporal trends. EMEP has recently started the preparation of an assessment report study which will be aimed at analyzing the links between observed trends and emission changes. National experts will be given a major role in that study whereas in the present paper we have a broader and more subjective perspective. As a background we refer to the previous EMEP assessment report (Lövblad et al., 2004) which presented an analysis of the first $25 \mathrm{yr}$ of measurement data. In Table 2 we list a number of recent publications addressing regional scale trends of European air pollution. This paper is based on the data reported to the EMEP database. These data have been validated through a quality assurance/quality control process involving the individual institutions responsible for the different sites and the EMEP-CCC as documented by the reports available in the EMEP-CCC series (www.emep.int). Other papers in the present EMEP ACP Special Issue present more in-depth analysis of specific datasets.

\section{Observational network and quality assurance}

The EMEP monitoring sites are located such that significant local influences (local emission sources, local sinks, topographic features, etc.) are minimised. The basic idea is that the data should be representative for a larger region. The site criteria are defined in the EMEP manual (EMEP/CCC, 2001), and the sites are classified as regional or global. Although the goal is to avoid that local sources unduly affect the observations, this can not be realized in an absolute sense. The major focus has been to avoid influence from significant industrial or transport related sources resulting in a network of rural sites (the siting criteria was originally based on recommendations outlined by WMO, 1974). Sites will to a varying degree be influenced by local and regional agricultural activities, various natural sources as well as other local sources (i.e. ammonia, pesticides, carbonaceous material, mineral dust etc.). A site which has a large spatial representativity for one given chemical compound may thus have low representativity for another variable. For an updated discussion on site representativity we refer to Henne et al. (2010) and references therein. In general one can assume that EMEP sites in general do represent the regional scale atmospheric composition, but for more in-depth studies of individual datasets, we recommend to also take additional metadata information into account. The observational data are reported to the EMEP-CCC every year with a time lag of $1.5 \mathrm{yr}$ (e.g. Hjellbrekke and Fjæraa, 2011, and references therein).

The EMEP monitoring focuses on species and parameters which are important for understanding the sources and exposure/fluxes of pollutants as well as to understand atmospheric processes in general. Data for more than 600 different variables have been reported to the EMEP database at EMEP-CCC (http://ebas.nilu.no), and the number is continuously growing (see Fig. 1) as new methodologies become 
Table 1. General overview of the EMEP monitoring program for the period 2009-2020, (UNECE, 2009).

\begin{tabular}{ll}
\hline Level-1 & Level-2 supersites \\
\hline - Main inorganic components in precipitation & $-\mathrm{PM}$ composition (EC/OC, mineral dust) \\
$\quad$ and in air & - Aerosol physical and optical properties \\
- Heavy metals in precipitation & $-\mathrm{CH}_{4}$ \\
- Ozone & - Tracers (CO and halocarbons) \\
- Gas particle nitrogen ratios (low cost) & - POPs in air and precipitation \\
$-\mathrm{PM}_{10}$ and $\mathrm{PM}_{2.5}$ mass & - Heavy metals in air \\
- Meteorology & - VOC \\
& -+ all level-1 components \\
\hline
\end{tabular}

available, and new environmental challenges are identified. The EMEP monitoring obligations are defined by the EMEP monitoring strategy (UNECE, 2009). The monitoring program is now built on activities assigned to three so-called levels. Level-1 consists of basic, well-established methods such as the monitoring of S- and N-deposition, ozone concentrations etc. Level-1 variables are measured at a fairly large number of sites. More advanced measurements are carried out at a subset of the sites, the so-called level-2 supersites, and is normally undertaken by scientific institutions. The level 2 sites are normally also part of the Global Atmosphere Watch program. An overview of the mandatory monitoring programme of EMEP is given in Table 1. In addition, EMEP makes use of data from research campaigns (level-3 monitoring) and other specific data relevant for understanding atmospheric processes. These research campaigns are often coordinated through the EMEP intensive measurement periods (Aas et al., 2012). The EMEP Task Force on Measurements and Modelling plays a central role in involving national experts in the development of the EMEP operational activities, including the monitoring strategies.

Ideally, the spatial density of sites should reflect the gradients in the air concentrations and deposition fluxes. The implementation of an adequate monitoring program has however been difficult in some regions. At present there is a particular need for more sites in the Mediterranean area and in the EECAA (Eastern Europe, Caucasus and Central Asia) region. Furthermore, a sufficiently short time resolution of the measurements is needed to allow an assessment of the atmospheric sources and processes. Hourly data are seen as ideal and feasible for some species (like ozone) whereas daily samples are requested for other variables where such a high time resolution is not realistic for economic or practical reasons (like aerosol chemical composition and wet deposition of $\mathrm{N}$ and $\mathrm{S}$ ). A time resolution longer than one day will normally inhibit process studies and the establishment of source-receptor relationships since the origin and history of the air masses will be masked. Some species or parameters are however expensive to measure and a longer sampling time may be acceptable. As the technology is developed, measurements with improved time resolution are be-
Table 2. Overview of some recent publications that have used EMEP data to assess air pollution trends in Europe. In addition there are a large number of studies which have made assessments based on national networks or individual measurement sites.

\begin{tabular}{ll}
\hline Regional scale trend assessments & Subject \\
\hline Konovalov et al. (2008) & Nitrogen oxides \\
Fagerli and Aas (2008) & Sulphur and nitrogen \\
Hole et al. (2009) & Sulphur and nitrogen \\
Dayan and Lamb (2005) & Deposition \\
Baldsano et al. (2005) & Air quality \\
Lövblad et al. (2004) & All subjects \\
Barmpadimos et al. (2012) & Particulate matter mass \\
Wilson et al. (2012) & Ozone \\
Monteiro et al. (2012) & Ozone \\
Colette et al. (2011) & Ozone, NO, PM \\
EEA (2009) & Ozone \\
Jonson et al. (2006) & Ozone \\
Vautard et al. (2006) & Ozone \\
Oltmans et al. (2006) & Ozone \\
Ordóñez et al. (2005) & Ozone \\
Solberg et al. (2005) & Ozone \\
Solberg et al. (2001) & Formaldehyde \\
Harmens et al. (2010) & Heavy metals \\
Heimbürger et al. (2010) & Trace metals \\
Pacyna et al. (2009) & Mercury, lead, cadmium \\
Wängberg et al. (2007) & Mercury \\
Kock et al. (2005) & Mercury \\
Slemr and Scheel (1998) & Mercury \\
Schuster et al. (2011) & PCBs, PBDEs \\
Hung et al. (2010) & POPs \\
Schuster et al. (2010) & PCBs \\
Becker et al. (2008) & HCHs \\
Dvorska et al. (2008) & POPs \\
Holoubek, et al. (2007) & POPs \\
Audrone (2006) & Benso(a)pyrene \\
Barber et al. (2005) & Hexachlorobenzene \\
\hline
\end{tabular}

coming available (Laj et al., 2009), and EMEP's strategic goal is to take benefit from such developments by encouraging researchers to take part in the monitoring programme.

The monitoring methods used in EMEP are chosen based on a compromise between several criteria: a sufficient 
precision is needed at low concentration levels, and the method should be robust and simple to apply in the field. If adequate international standards are available from Comité Européen de Normalisation (CEN) or WMO, EMEP seeks to apply the same criteria. There are some exceptions, for example if CEN standards are mainly targeting measurements of air quality in urban areas, the methods may be inadequate at EMEP sites having low concentrations. Where reference methods are not available, EMEP has developed its own methodologies through the competence of national experts contributing to the programme. In addition to applied reference methods and standard operation procedures, EMEP conducts laboratory- and field intercomparison of most components defined by the monitoring programme. Some species are tested annually, i.e. sulphur, nitrogen (Uggerud and Hjellbrekke, 2011a), heavy metals (Uggerud and Hjellbrekke, 2011b) and EC/OC (Cavalli and Putaud, 2011), while others are intercompared more sporadically, i.e. POPs (Schlabach et al., 2011). Field intercomparisons are an important part of the quality assurance programme in EMEP to document the overall uncertainty in the methods used; i.e. for main components in air (Aas et al., 2007) and deposition of heavy metals (Aas et al., 2009).

\section{Data analysis and statistical methods}

The data used in this work is based on public data available in the EMEP database (http://ebas.nilu.no). The EMEP database web interface also offers additional meta information related to the individual data sets available in the database. This study has focused on time series and sites which offer consistent long-term information and a data capture satisfying criteria listed below. Coordinates for sites specifically presented in this study are given in Appendix A. For continuous measurements a data capture of $75 \%$ on an annual basis has been required to calculate annual statistics; for non-continuous measurements such as heavy metals, VOC and POPs, the requirement is that at least nine months with data are available. Annual means of components in precipitation are volume weighted, and concentrations below the detection limit have been set equal to one half of the actual limit. Further details on how the data are treated are found in the annual data reports (i.e. Hjellbrekke and Fjæraa, 2011). For the statistical analysis, the non-parametric "Mann-Kendall Test" has been used on annual means for detecting and estimating trends (Gilbert, 1987). The MannKendall test has become a standard method when missing values occurs and when data are not normally distributed. In parallel to this, the Sen's slope estimator has been used to quantify the magnitude of potential trends. Thus, the Sen's slope is used to estimate the percent reduction in the concentration level while the Mann-Kendall test is used to indicate the significance level of the trend. Statistical calculations have been carried out using the MAKESENS software (Salmi et al., 2002) which was developed to be used for the previous EMEP assessment (Lövblad et al., 2004). In MAKESENS a two tailed test is used for four different significance levels $(\alpha: 0.1,0.05,0.01$ and 0.001$)$. In this work we have included all these confidence levels when defining whether the trend is significant or not. The average per cent change and standard deviation are calculated for all the sites, and not only for those with a significant trend.

In estimating the per cent change per decade for sulphur compounds (see Fig. 2), we first estimated representative values for each of the years 1980, 1990, 2000 and 2009. These values were then used to calculate a percent change from one reference year to another. Only sites with measurements for the whole period and in all media (gas, aerosol and precipitation) were included, 14 in all. The estimated concentrations were calculated using the following approach:

- $X_{1980}$ : Sen's slope estimate based on the period 1980-2009.

- $X_{1990}$ : Sen's slope estimate based on the period 1990-2009.

$-X_{2000}$ : Average of the measured values for the three years 1999-2001.

- $X_{2009}$ : Sen's slope estimate based on the period 1990-2009.

A similar procedure was used for reduced- and oxidized nitrogen, but due to less data available during the 1980, the analysis was based on data from 1990 only. In contrary to sulphur, there are relatively few sites with concurrent measurements of reduced and oxidized nitrogen in both air and precipitation (Fagerli and Aas, 2008), and for decadal trends we have chosen to use measurements from all long term measurement sites even if there are only measurements in either air or precipitation.

All emission changes referred to were calculated from the official EMEP emission data which also are used as input for the EMEP models (EMEP/CEIP, 2011). Only emission data from the previous EMEP geographical domain (the domain was extended in 2008 as described in http://www.emep.int/ grid/griddescr.html) has been used to ensure comparable data for the complete time period. Emissions data used for trend analysis are presented in Appendix B.

\section{Major inorganic compounds}

\subsection{Introduction}

Major inorganic compounds include about 30 different sulphur-, nitrogen- containing compounds, base cations and sea salts present as gases, particles or dissolved in precipitation. Their effects on the environment occur through a range of processes including acidification (sulphur, nitrogen and base cations), eutrophication (nitrogen), impact on materials and human health (particulate matter). The observations 

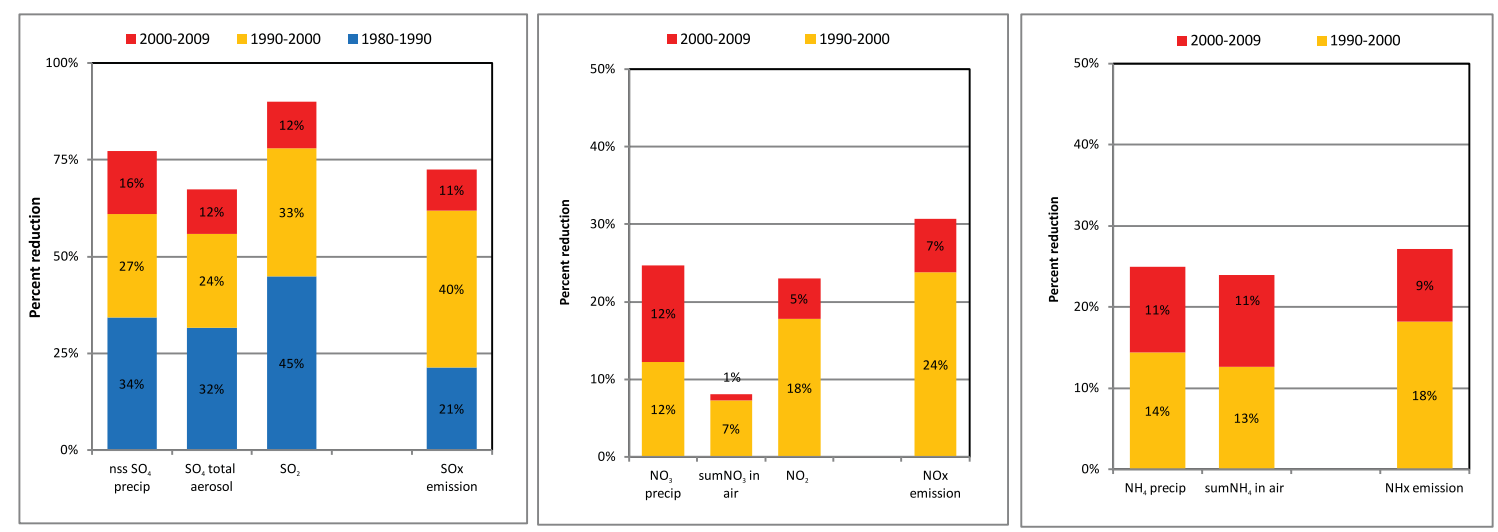

Fig. 2. Average observed reduction in sulphur and nitrogen components compared to the emission reductions in Europe for the different ten years period from 1980 for sulphur and 1990 for nitrogen. Sulphur trends are calculated from the 14 sites with measurements of all three components since 1980, while for nitrogen the same number of sites, as shown in Table 3, are used, and it is not necessarily the same site used for all the components.

of inorganic compounds remain a key activity of EMEP, and time series now extend over nearly $40 \mathrm{yr}$. Measurements are made of both air and precipitation samples.

Sulphur and nitrogen deposition causing acidification and eutrophication of ecosystems, rivers and lakes is well documented in the literature throughout the last four decades (Ottar et al., 1984; WGE, 2011; Slootweg et al., 2010; Lorenz and Granke, 2009; Skjelkvåle et al., 2005). The excess deposition above the critical load for acidity (defined as "A quantitative estimate of an exposure to one or more pollutants below which significant harmful effects on specified sensitive elements of the environment do not occur according to present knowledge") has been significantly reduced since 1980. The European area at risk of acidification was $11 \%$ in 2000 (Slootweg et al., 2010) and is expected to drop to $4 \%$ by 2020 based on current legislated emission reduction targets (WGE, 2011). Parts of Scandinavia are likely to be exposed to acidic deposition at a level requiring continued liming of fresh water systems in order to avoid fish death unless further reductions are agreed. Eutrophication on the other hand will continue to be a major environmental problem in Europe. The risk of eutrophication will affect about $40 \%$ of the natural area in Europe in 2020 under the current baseline scenario (WGE, 2011; Slootweg et al., 2010). A European nitrogen assessment was recently published (Sutton et al., 2011), describing the various nitrogen sources and the cascade of effects ranging from pollution of air, water and soil to climate change and reduction of biodiversity. Furthermore, even if acidification due to sulphur is being reduced, sulphur remains an environmental problem since sulphate is a major aerosol constituent, which is important for human health and climate forcing.

\subsection{Spatial distribution}

The monitoring network within the OECD project only covered parts of central Europe, UK and Scandinavia. Sulphur was measured at all sites, whereas other components were measured only at less than one third of the sites. By 2009 the network covered the whole of Europe as well as areas in Central Asia and Caucasus. Still, the number of monitoring sites in Eastern Europe is considered inadequate (e.g. Tørseth and Hov, 2003; UNECE, 2009). The development in the number of sites as well as the change in measured concentrations can be seen in Fig. 3. In 2009, 127 sites reported data for at least one component in air or precipitation, and 90 of these performed measurements of main ions in precipitation.

The highest concentrations of non-sea-salt (nss) sulphate (sulphate corrected for the contribution from sea salt) in precipitation in 2009 were $0.7-1.0 \mathrm{mg} \mathrm{S}^{-1}$ in Serbia and Eastern Europe. The lowest concentrations $\left(\sim 0.1 \mathrm{mg} \mathrm{S}^{-1}\right)$ were observed in Scandinavia (Hjellbrekke and Fjæraa, 2011). The spatial patterns of nss $\mathrm{S}$ concentration in precipitation and wet deposition in Europe are fairly similar. However, orographic effects lead to distinct local maxima in wet deposition. Sites in southern Norway and the region around the Alps typically experience high wet deposition due to high annual precipitation amounts. The concentrations of $\mathrm{SO}_{2}$ and $\mathrm{SO}_{4}^{2-}$ in air are similar to the distribution of sulphate in precipitation although somewhat more heterogeneous (airborne concentrations of $\mathrm{SO}_{4}^{2-}$ have not been corrected for the sea salt contribution since the measurement programme only recently has been extended to include the determination of $\mathrm{Na}^{+}, \mathrm{Mg}^{2+}$ or $\mathrm{Cl}^{-}$allowing such corrections). The highest levels of sulphate in aerosols in 2009 were observed in Austria, Poland, Hungary and Lithuania. Relatively high levels were also found at sites in Spain, the Netherlands and Cyprus. Furthermore, very high levels of $\mathrm{SO}_{2}$ were measured in Macedonia and Serbia with concentration levels of 

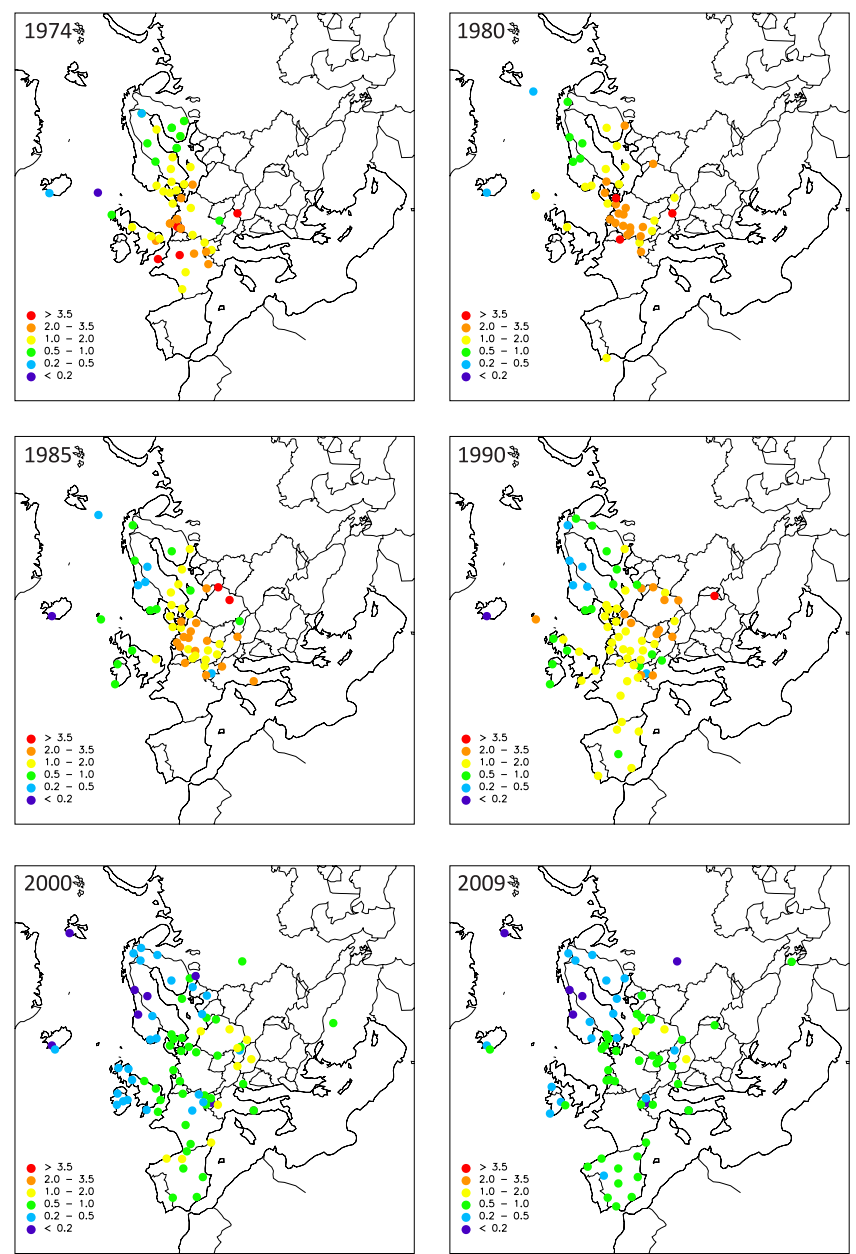

Fig. 3. Annual mean concentrations of $\mathrm{SO}_{4}^{2-}$ in aerosols from 1974 to 2009. Unit: $\mu \mathrm{g} \mathrm{S} \mathrm{m}^{-3}$.

7-9 $\mu \mathrm{g} \mathrm{S} \mathrm{m}^{-3}$ which is four times higher than typically found at sites in Central Europe (Hjellbrekke and Fjæraa, 2011).

The highest concentrations of total inorganic nitrate ions in precipitation in 2009 were in the order of $1-2 \mathrm{mg} \mathrm{N}^{-1}$ (Hjellbrekke and Fjæraa, 2011). These levels are typically seen in regions with high population density and associated emissions from traffic or power generation (EMEP/CEIP, 2011), like sites in Germany, Czech Republic, Poland and Denmark. The lowest concentrations $\left(<0.4 \mathrm{mg} \mathrm{N}^{-1}\right)$ were observed in the outskirts of Europe, i.e. Scandinavia, Ireland and Portugal. Wet deposition of nitrogen ranged from less than $1 \mathrm{~kg} \mathrm{Nha}^{-1} \mathrm{yr}^{-1}$ to more than $20 \mathrm{~kg} \mathrm{Nha}^{-1} \mathrm{yr}^{-1}$. On average, the reduced and oxidized nitrogen contribute approximately with equal amounts to the total $\mathrm{N}$ deposition. However, in the Benelux area and in Ireland, the contribution of ammonium deposition exceeds that of nitrate, reflecting regional agricultural sources of ammonia. In contrast, wet deposition of oxidized nitrogen is generally somewhat higher than reduced nitrogen in Scandinavia and the Mediterranean, except for a few sites influenced by nearby agriculture.
The air concentrations of $\mathrm{NO}_{2}$ are highest around the major emission sources, and during 2009, levels exceeding $4 \mu \mathrm{g} \mathrm{N} \mathrm{m}^{-3}$ were seen in the Benelux area, Italy and Greece, whereas levels of the order of $3 \mu \mathrm{g} \mathrm{m}^{-3}$ were observed in southeast UK (Hjellbrekke and Fjæraa, 2011). Relatively low concentrations of $\mathrm{NO}_{2}$ are seen in Spain, and the lowest levels (less than $0.5 \mu \mathrm{g} \mathrm{N} \mathrm{m}^{-3}$ ) are observed in Scandinavia. The air concentrations of the other gaseous and particulate nitrogen compounds show a more scattered pattern. The highest sum of nitric acid + nitrate (above $1 \mu \mathrm{g} \mathrm{N} \mathrm{m}^{-3}$ ) was observed at sites in France, Austria and Switzerland, while for sum of ammonia + ammonium concentrations above $2 \mu \mathrm{g} \mathrm{N} \mathrm{m}{ }^{-3}$ are seen in Switzerland, Czech Republic, Italy, Austria, Hungary and France (Hjellbrekke and Fjæraa, 2011).

Knowledge of the nitrogen dry deposition fluxes is important for understanding the observed ambient trends. Further, in order to quantify effects on ecosystems, one clearly needs to quantify the dry deposition flux (e.g. Sutton et al., 2011). Monitoring of dry deposition fluxes is however a recent addition to the EMEP monitoring program, and has so far mainly been made in relation to research projects. In particular, the European Union integrated project NitroEurope, has established a network of advanced flux measurements at a few selected sites together with a regional scale network of low cost denuders (Skiba et al., 2009). These measurements have been combined with various inferential models to calculate the dry deposition (Flechard et al., 2011). The results from these models show large differences in dry deposition flux estimates: whereas some methods gave values exceeding $30-40 \mathrm{~kg} \mathrm{Nha}^{-1} \mathrm{yr}^{-1}$ over parts of the Netherlands and Belgium, others gave $\sim 20 \mathrm{~kg} \mathrm{Nha}^{-1} \mathrm{yr}^{-1}$ at the same sites (Flechard et al., 2011). These large differences illustrate the challenge in estimating the dry deposition of nitrogen in Europe.

Mineral dust is an important component with respect to critical load since it counterbalances the acid deposition. The wet deposition of calcium in Europe is significantly influenced by Saharan dust. Wet deposition rates exceeding $10 \mathrm{~kg} \mathrm{Ca} \mathrm{ha}^{-1} \mathrm{yr}^{-1}$ are observed at sites in Spain, Portugal, Italy, Serbia and Croatia (Hjellbrekke and Fjæraa, 2011). Sites with high precipitation amounts located close to the sea also experience high rates of wet deposition due to sea salt calcium. In Belarus the wet deposition of calcium exceeds $10 \mathrm{~kg} \mathrm{~N} \mathrm{ha}^{-1} \mathrm{yr}^{-1}$ which may largely be due to anthropogenic emissions. It should be noticed, though, that the site in Belarus uses a bulk collector (daily sampling), and thus a significant amount of dry dust deposition may be included if the site is influenced by local Ca emissions. On the low end of the scale several sites in Scandinavia receive less than $1 \mathrm{~kg} \mathrm{Ca} \mathrm{ha}^{-1} \mathrm{yr}^{-1}$ (Hjellbrekke and Fjæraa, 2011).

The $\mathrm{pH}$ value reflects the balance between acidic ions and base cations. The lowest pH in Europe is observed in the Eastern part of the continent which has a relatively high sulphate deposition and a low base cation deposition. The 
Table 3. Average trends in concentration of major components in air and precipitation and the number of sites with significant trends in accordance to Mann Kendall test for the periods 1980-2009 and 1990-2009 compared to the emission trends in Europe (EMEP/CEIP, 2011).

\begin{tabular}{|c|c|c|c|c|c|c|}
\hline \multirow[b]{2}{*}{ Comp } & \multirow[t]{2}{*}{ No. of sites } & \multicolumn{2}{|c|}{ Sites with sign. Trend } & \multicolumn{2}{|c|}{ Trends in conc } & \multirow{2}{*}{$\begin{array}{r}\text { Emission } \\
\text { trends }\end{array}$} \\
\hline & & decrease & increase & Avg. & SD & \\
\hline \multicolumn{7}{|l|}{ Trends 1980-2009 } \\
\hline $\mathrm{SO}_{2}$ & 19 & $100 \%$ & $0 \%$ & $-92 \%$ & $6 \%$ & \multirow{3}{*}{$-73 \%$} \\
\hline $\mathrm{SO}_{4}$ air & 19 & $95 \%$ & $0 \%$ & $-70 \%$ & $20 \%$ & \\
\hline nss $\mathrm{SO}_{4}$ in precipitation & 21 & $100 \%$ & $0 \%$ & $-80 \%$ & $11 \%$ & \\
\hline $\mathrm{NO}_{2}$ & 8 & $88 \%$ & $0 \%$ & $-48 \%$ & $26 \%$ & \multirow{2}{*}{$-31 \%$} \\
\hline $\mathrm{NO}_{3}$ in precipitation & 18 & $83 \%$ & $0 \%$ & $-30 \%$ & $16 \%$ & \\
\hline $\mathrm{NH}_{4}$ in precipitation & 18 & $67 \%$ & $6 \%$ & $-27 \%$ & $38 \%$ & \multirow[t]{3}{*}{$-32 \%$} \\
\hline $\mathrm{Ca}$ in precipitation & 10 & $80 \%$ & $0 \%$ & $-47 \%$ & $29 \%$ & \\
\hline $\mathrm{pH}\left(\mathrm{as} \mathrm{H}^{+}\right)$in precipitation & 22 & $91 \%$ & $0 \%$ & $-74 \%$ & $20 \%$ & \\
\hline \multicolumn{7}{|l|}{ Trends 1990-2009 } \\
\hline $\mathrm{SO}_{2}$ & 31 & $90 \%$ & $0 \%$ & $-75 \%$ & $25 \%$ & \multirow{3}{*}{$-65 \%$} \\
\hline $\mathrm{SO}_{4}$ air & 30 & $87 \%$ & $0 \%$ & $-56 \%$ & $16 \%$ & \\
\hline nss $\mathrm{SO}_{4}$ in precipitation & 36 & $100 \%$ & $0 \%$ & $-64 \%$ & $11 \%$ & \\
\hline $\mathrm{NO}_{2}$ & 28 & $68 \%$ & $11 \%$ & $-23 \%$ & $39 \%$ & \multirow{3}{*}{$-31 \%$} \\
\hline sum $\mathrm{NO}_{3}$ air & 19 & $42 \%$ & $5 \%$ & $-8 \%$ & $30 \%$ & \\
\hline $\mathrm{NO}_{3}$ in precipitation & 36 & $69 \%$ & $0 \%$ & $-25 \%$ & $13 \%$ & \\
\hline sum $\mathrm{NH}_{4}$ air & 20 & $75 \%$ & $15 \%$ & $-24 \%$ & $56 \%$ & \multirow{2}{*}{$-29 \%$} \\
\hline $\mathrm{NH}_{4}$ in precipitation & 35 & $54 \%$ & $3 \%$ & $-25 \%$ & $31 \%$ & \\
\hline Ca precip & 34 & $35 \%$ & $3 \%$ & $-26 \%$ & $42 \%$ & \\
\hline $\mathrm{pH}\left(\right.$ as $\left.\mathrm{H}^{+}\right)$in precipitation & 37 & $68 \%$ & $0 \%$ & $-76 \%$ & $55 \%$ & \\
\hline
\end{tabular}

highest $\mathrm{pH}$ is observed in Spain and parts of Italy (Hjellbrekke and Fjæraa, 2011).

\subsection{Temporal trends in concentration}

During the OECD project (OECD, 1977), eleven participating countries with totally fifty sites measured major ions in precipitation, and $\mathrm{SO}_{2}$ and $\mathrm{SO}_{4}^{2-}$ in air, during 1972-1975. These data are included here together with the EMEP data which started in October 1977.

21 of the sites in operation during 2009 have time series extending back to 1980 , while 36 extend back to 1990 . For measurements of $\mathrm{SO}_{2}$ and $\mathrm{SO}_{4}^{2-}$ in air there are a similar number of stations. Nitrogen has been continuously measured as ammonium and nitrate in precipitation at 18 sites from 1980, while $\mathrm{NO}_{2}$ has been measured only at 8 sites. Measurements of gaseous nitrate and ammonium started later and about 20 sites have continuous time series extending back to 1990. Figure 4 illustrates the long-term data series of daily observations throughout this period. Figure 3 shows annual averages of sulphate in aerosols during the period from 1974 to 2009 . Table 3 gives an overview of the trend anal- ysis for major ions in air and precipitation for the periods 1980-2009 and 1990 to 2009. Figure 2 shows the trends in measurements for various sulphur and nitrogen components for different decades. As seen from Table 3 and Fig. 2, Europe has experienced large reductions in $\mathrm{S}$ emissions during the last decades. In the late 1970s, emission control programs started, including a number of measures like installation of flue gas desulphurization units at power plants and reduction of the sulphur content of fuel. The large reductions resulted however also from the changes in political and economical situation in Eastern Europe (Lövblad et al., 2004; Vestreng et al., 2007).

The reported emission reductions in sulphur dioxide and sulphate (Appendix B) were $73 \%$ and $65 \%$ from 1980 to 2009 and from 1990 to 2009, respectively (EMEP/CEIP, 2011). The EMEP monitoring results of sulphate in air and precipitation reflect the emission changes throughout Europe (Table 3). For $\mathrm{SO}_{2}$, trends indicate even larger reductions than reported emission reductions, and a suggested explanation has been that the oxidizing capacity of the atmosphere may have remained unchanged while the amount of 

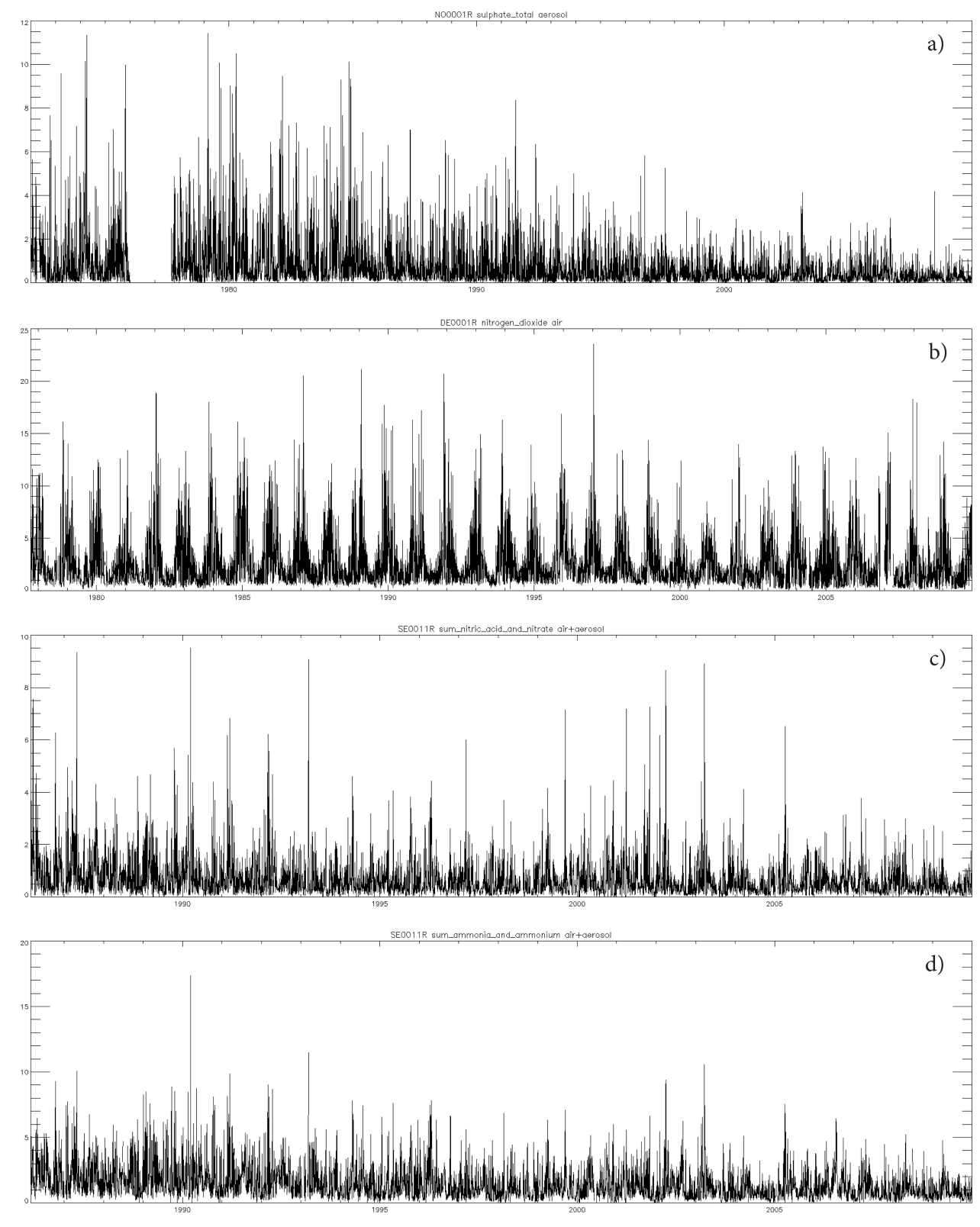

Fig. 4. Time series of daily air concentrations of (a) $\mathrm{SO}_{4}^{2-}$ (unit: $\mu \mathrm{g} \mathrm{S} \mathrm{m}{ }^{-3}$ ) at Birkenes, Norway, (b) $\mathrm{NO}_{2}$ (unit: $\mu \mathrm{g} \mathrm{N} \mathrm{m}^{-3}$ ) at Westerland, Germany and (c) sum $\mathrm{HNO}_{3}+\mathrm{NO}_{3}^{-}$, and (d) $\mathrm{NH}_{3}+\mathrm{NH}_{4}^{+}$(unit: $\mu \mathrm{g} \mathrm{N} \mathrm{m}{ }^{-3}$ ) at Vavihill, Sweden.

$\mathrm{SO}_{2}$ available for oxidation has become smaller (Lövblad et al., 2004). Further, the $\mathrm{SO}_{2}$ dry deposition rates may have changed with time due to changes in the ambient ammonia concentrations (Fowler et al., 2009 and references therein). Data show that the average concentrations as well as the frequency and magnitude of sulphur peak episodes have decreased. The trend is dominated by the trend in concentrations during winter (Lövblad et al., 2004).

Presently, the largest emission source of oxidised sulphur in Europe is power generation (Vestreng et al., 2007; EMEP/CEIP, 2011). Emissions from international shipping are of growing concern since they are not regulated in current protocols, and thus have a potential to counteract the reduced land-based emissions (Dore et al., 2007; Cofala et al., 2007 and Eyring et al., 2010). In 2009, the ship emissions accounted for about $15 \%$ of the total sulphur emissions in Europe (EMEP/CEIP, 2011).

There have also been quite substantial reductions in emissions of nitrogen oxides during the last decades (Vestreng et al., 2009; EMEP/CEIP, 2011). The variation from country to country is however larger for nitrogen compounds compared to sulphur (Lövblad et al., 2004). The total $\mathrm{NO}_{\mathrm{x}}$ emissions 
were fairly constant between 1980 and 1990, although a slight increase occurred in the land based emissions due to increased traffic (Vestreng et al., 2009; Lövblad et al., 2004). From 1990 to 2009 the $\mathrm{NO}_{\mathrm{x}}$ emissions in Europe decreased by $31 \%$, Table 3 (EMEP/CEIP, 2011) and most of this reduction occurred in the first decade (Fig. 2). The reductions were mainly caused by a change from burning of coal and gas to nuclear power (Lövblad et al., 2004). The economic recovery in Eastern Europe led to increased $\mathrm{NO}_{\mathrm{x}}$ emissions from road traffic in this area after 2000 (Vestreng et al., 2009). On the other hand, $\mathrm{NO}_{\mathrm{x}}$ emissions from traffic in Western European decreased, even though fuel consumption increased.

The European trend of $\mathrm{NO}_{\mathrm{x}}$ emissions are reflected in the measurements (Table 3). From 1990 to 2009, nitrogen dioxide and nitrate in precipitation decreased, on average, by $23 \%$ and $25 \%$, respectively. Most of these changes occurred in the first decade between 1990 and 2000 (Fig. 2). Interestingly, the concentrations of total airborne nitrate decreased on average only $8 \%$, and fewer sites show a significant change (Table 3 ). These differences in trends can partly be explained by a shift in equilibrium towards more particulate ammonium nitrate relative to nitric acid caused by a reduction in sulphur dioxide emissions (Fagerli and Aas, 2008). A more rapid oxidation of $\mathrm{NO}_{\mathrm{x}}$ may also have contributed (Monks et al., 2009). The total reduction in observed concentrations of oxidized nitrogen compounds from 1980 to 2009 is somewhat larger than from 1990 to 2009. A similar trend is not seen in the emission data, but the discrepancy may partly be explained by significant changes in the number and location of sites when comparing the 1980s with the more recent years.

The total European ammonia emissions decreased by $29 \%$ from 1990 to 2009 (Table 3) (EMEP/CEIP, 2011), though with large regional differences. A majority of the EMEP sites show a decreasing trend both in air and precipitation, on average $24-25 \%$. It should be noted that some EMEP sites are, due to their location in rural districts, partly affected by local ammonia emissions. Concentrations were fairly constant from 1980 to 1990 , consistent with the small reported changes in emissions during that period. The observed downward trends were somewhat larger during the period 19902000 compared to the period 2000-2009 (Fig. 2).

The deposition of base cations also decreased during the past $30 \mathrm{yr}$ (Table 3). A majority of the EMEP sites showed a decreasing trend of calcium in precipitation with an average decrease of $47 \%$ from 1980 to 2009 and $26 \%$ from 1990 to 2009 (Table 3). In the early 1990s, the closing of many lignite-fired power stations, iron and steel smelters as well the implementation of effective abatement technologies for sulphur caused a reduction also in the emissions of base cations (Lövblad, 2004; Hellsten et al., 2007).

Since 1980, large areas have experienced an increase in $\mathrm{pH}$ in the order of $0.5-0.6 \mathrm{pH}$ units, corresponding well with sulphur trends. Even though there has been a decrease in both sulphate and base cations, the sulphate reductions have been larger. Furthermore, nitrate has also been reduced. At the 22 sites with long term $\mathrm{pH}$ measurements from 1980 to 2009 the average decrease in $\mathrm{H}+$ concentration was $74 \%$, Table 3 .

\section{Particulate matter}

\subsection{Introduction to particulate mass measurements}

Aerosols remains a major challenge to atmospheric science due to their detrimental health effects and influence on the Earth's radiative balance, and thus climate. On a worldwide basis, the annual number of premature deaths caused by cardiovascular and pulmonary diseases following ambient air particulate matter (PM) exposure is estimated to be in the order of 800000 (World Health Organization (WHO), 2002). Furthermore, light-scattering aerosol such as sulphate masks the observed warming from greenhouse gases with an unknown strength over the industrial era resulting in high uncertainty in the climate sensitivity (e.g. the temperature response of a doubling of $\mathrm{CO}_{2}$ ) (Forster et al., 2007). During the last years, short-lived climate forcers, especially tropospheric ozone and black carbon - a light absorbing aerosol component - have received increased attention. There is scientific confidence that mitigation and control of black carbon particles and tropospheric ozone will have benefits both for health and climate change. Black carbon and tropospheric ozone have substantial regional and global climate impacts. According to a recent integrated assessment (UNEP/DEWA, 2011), reducing black carbon and tropospheric ozone starting now will slow down the rate of climate warming significantly within the first half of this century, with particular importance for changes in the Himalayan and Arctic regions (UNEP/DEWA, 2011). The assessment indentifies a set of measures, and full implementation of these would reduce future global warming by $0.5^{\circ} \mathrm{C}\left(0.2-0.7^{\circ} \mathrm{C}\right)$. This further emphasises the importance of long term measurements and understanding of these variables and their precursors, also in the future. CLRTAP recently established a "Working Group on Black Carbon" to address the inclusion of BC as a component of PM in the process of the revision of the Gothenburg Protocol. EMEP observations include both elemental carbon (EC) (based on thermo-optical analysis, giving a measure of the mass concentration) and "black carbon" (based on the absorption of light using spectroscopic methods, giving a measure of the aerosol optical properties). EC measurements have been part of the level-2 programme since 2004, and BC measurements were introduced at level-2 in 2010 (this was previously a level-3 activity) albeit time series extend further back. While aerosol chemistry had been a key variable of EMEP since its initiation, an increased concern about public health led to the first strategic discussions of including particulate mass measurements at a joint EMEP/WMO workshop in 1997 (EMEP-WMO, 1997), and which was followed up with a more in depth workshop in Interlaken in 
1999 (EMEP-WMO, 2000; Lazaridis et al., 2002). The need for more detailed optical and physical characterisation of aerosols in order to address their impact on the radiative balance and climate system is essential and was adopted (Kahnert et al., 2004) by EMEP and included in monitoring strategy for 2004-2009. The measurements of physical and optical parameters - including those of $\mathrm{BC}$ - will however not be discussed here.

The guidelines for particle mass measurements in EMEP have been harmonized with what has been specified in the EU's air quality directives (EU, 1999, 2008) and the standards developed in CEN $(1999,2005)$. The initial priority of EMEP was to measure $\mathrm{PM}_{10}$, and the oldest aerosol mass measurements in EMEP from Switzerland, Czech Republic and Great Britain started in 1996 and 1997. In addition, at several sites mainly in Germany and Switzerland, there are very old measurements for total suspended particulate matter (TSP) all the way back to 1977 (additional data are available from national networks, but here only data from background sites being reported to EMEP are considered). The methodologies for these measurements are poorly described, and the size cut off is unknown, and therefore these data are difficult to use for quantification of the mass load, but these measurements are valuable indicators of temporal changes in PM mass concentrations.

The number of sites measuring $\mathrm{PM}_{10}$ and $\mathrm{PM}_{2.5}$ has steadily increased throughout the last decade. For 2009, mass concentrations of PM are reported for 65 regional or global background sites ( 61 for $\mathrm{PM}_{10} ; 40$ for $\mathrm{PM}_{2.5}$ and 6 for $\mathrm{PM}_{1}$ ) (Fig. 1, Hjellbrekke and Fjæraa, 2011; EMEP, 2011). Even though the number of sites has increased during the last years, it is worth noticing that several sites have unsatisfactory data coverage, and different methodologies are used hampering the comparability across the network, thus improvements in data quality for mass measurements is a priority for the years to come.

\subsection{Spatial distribution of mass concentration}

The lowest measured concentrations of $\mathrm{PM}_{10}$ are generally observed in the northern and north-western parts of Europe, i.e. the Nordic countries, remote areas of the British Isles, and for high altitude sites on the European mainland reflecting both population density and distanse to major anthropogenic sources (Fig. 5, EMEP, 2011; Putaud et al., 2010). The highest levels are seen in the southern parts of Europe due to influence by both anthropogenic sources as well as dust outbreaks (Putaud et al., 2010; Querol et al., 2009). The regional variation in $\mathrm{PM}_{10}$ and $\mathrm{PM}_{2.5}$ are quite similar as illustrated in Fig. 5. The mean $\mathrm{PM}_{10}$ concentration for all EMEP sites was about $15 \mu \mathrm{g} \mathrm{m}^{-3}$ in 2009 (range 4 to $30 \mu \mathrm{g} \mathrm{m}^{-3}$ ), while the mean concentration of $\mathrm{PM}_{2.5}$ was about $10 \mu \mathrm{g} \mathrm{m}^{-3}$ (range 3 to almost $20 \mu \mathrm{g} \mathrm{m}^{-3}$ ) (EMEP, 2011). The annual mean concentration of $\mathrm{PM}_{1}$ ranges from 3 to $12 \mu \mathrm{g} \mathrm{m}^{-3}$ for the six sites with measurements in 2009 .
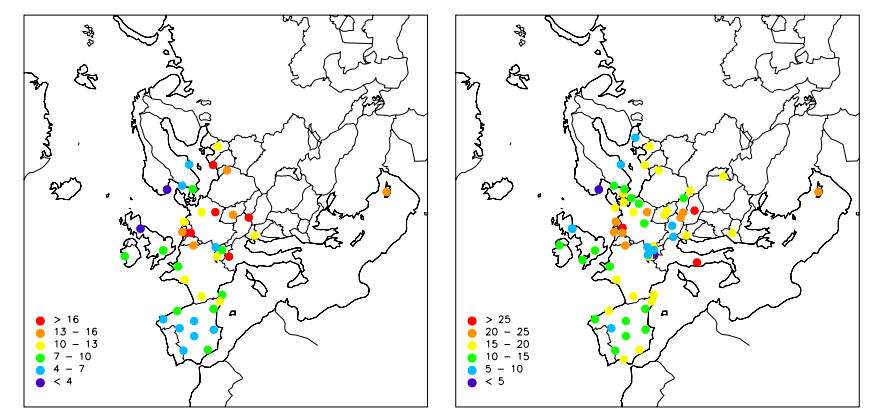

Fig. 5. Geographical distribution of $\mathrm{PM}_{2.5}$ (left) and $\mathrm{PM}_{10}$ (right) in 2009. Unit: $\mu \mathrm{g} \mathrm{m}^{-3}$.

The annual mean regional background $\mathrm{PM}_{10}$ concentrations are below the EU limit value of $40 \mu \mathrm{g} \mathrm{m}^{-3}$ (EU, 2008) all over of Europe, but a few sites exceed the WHO recommended air quality guidelines (WHO, 2005) of both $\mathrm{PM}_{10}$ and $\mathrm{PM}_{2.5}$, which are set to 20 and $10 \mu \mathrm{g} \mathrm{m}^{-3}$ for the annual mean, respectively. A comparison of the regional background measurements of EMEP with the urban background $\mathrm{PM}_{2.5}$ data reported the European Air Quality Database - AirBase (http://www.eea.europa.eu/data-and-maps/data/ airbase-the-european-air-quality-database-6) shows that more than $60 \%$ of the urban background concentration is likely to be attributed to the rural background contribution (EMEP, 2011; Putaud et al., 2010).

The relative contribution of fine and coarse particles however varies across Europe. $\mathrm{PM}_{2.5} / \mathrm{PM}_{10}$ ratios are available at 32 sites for the year 2009. The relative contribution of the fine fraction in $\mathrm{PM}_{10}$ is largest in central Europe (0.6-0.8). This is predominantly due to anthropogenic sources, but also biogenic secondary organic aerosols (BSOA) can contribute substantially, in particular during summer (Gelencser et al., 2007). The fraction of fine PM is on average smaller (0.4$0.6)$ at the sites in southern Europe, where windblown dust has a large influence (Querol et al., 2009). Relatively low $\mathrm{PM}_{2.5}$ to $\mathrm{PM}_{10}$ ratios (0.5) are seen for sites close to the coast due to the presence of coarse sea salt particles. As well as BSOA, primary biological aerosol particles (PBAP) are found to be a major contributor to the Scandinavian sites during the vegetative season (Yttri et al., 2011a, b) contributing to the low $\mathrm{PM}_{2.5}$ to $\mathrm{PM}_{10}$ ratios.

\subsection{Chemical speciation of particulate matter}

Chemical analysis of the ambient aerosol provides essential information about the various sources contributing to the aerosol loading, as well as about chemical and physical processes taking place in the atmosphere. The chemical composition is generally quite different across Europe: on average there is more carbonaceous matter in $\mathrm{PM}_{10}$ in Central Europe, more nitrate in North-western Europe, and more mineral dust in southern Europe (EMEP, 2011; Putaud et al., 2010). A problem in assessing the chemical speciation is that 
the necessary diversity of chemical species is rarely available for a full year, but rather for a few selected sites during research campaigns and the EMEP Intensive Monitoring periods (Aas et al., 2012).

Some species are however measured continuously. Secondary inorganic aerosols (SIA) have been monitored for decades, however not with artefact free methods to differentiate the gas/particle partitioning of semi-volatile nitrogen species. In 2009, concurrent measurements of sulphate and $\mathrm{PM}_{10}$ were performed at a total of 38 sites, while 27 and 18 sites reported nitrate and ammonium respectively. At the majority of these sites, SIA is collected using a sampler with an undefined cut-off whereas at a few sites a sampler with a $\mathrm{PM}_{10}$ inlet is applied. By assuming that these ions are generally found in $\mathrm{PM}_{10}$ size range, the average relative contribution of SIA to $\mathrm{PM}_{10}$ are $13 \pm 3 \%$ for $\mathrm{SO}_{4}^{2-} ; 14 \pm 8 \%$ for $\mathrm{NO}_{3}^{-}$ and $7 \pm 3 \%$ for $\mathrm{NH}_{4}^{+}$during 2009 (EMEP, 2011). The highest contribution of SIA is in central Europe, with the highest level of sulphate and especially ammonium during summer, and nitrate having increased levels during the cold season, particularly in the Mediterranean area. The contribution of sea salt to aerosol mass is highly dependent on distance to the sea, i.e. from about $0.5 \%$ at some continental sites and around $15 \%$ at sites close to the coast.

The carbonaceous matter is a significant component of the atmospheric aerosol mass, accounting for $10-40 \%$ of the $\mathrm{PM}_{10}$ at the EMEP sites (Yttri et al., 2007). The EMEP program includes measurements of elemental carbon (EC) and organic carbon (OC) at 10 sites in 2009. Previously, few observations of the carbonaceous fraction were available, and further has there been a lack of comparable observations of $\mathrm{EC} / \mathrm{OC}$ data. Due to the high importance of EC/OC for both climate and health issues, EMEP performed a dedicated campaign to derive the first European wide coordinated monitoring effort of EC and OC (Yttri et al., 2007). Similarly, the CARBOSOL (Legrand and Puxbaum, 2007; Pio et al., 2007; Simpson et al., 2007a) and EUCAARI projects (Kulmala et al., 2009) have offered important information on the regional occurrence of EC/OC. An increased number of countries and sites have started reporting data of EC and OC. The harmonization of methodology has improved through the efforts made within the EUSAAR project (Cavalli et al., 2010), and this will continue within the EU project ACTRIS.

Annual mean concentrations of EC (both for $\mathrm{PM}_{10}$ and $\mathrm{PM}_{2.5}$ ) vary by a factor of 15 from the lowest with $0.09 \mu \mathrm{g} \mathrm{C} \mathrm{m}^{-3}$ at Birkenes, Southern Norway, to the highest annual mean concentration at Ispra in Italy with $1.4 \mu \mathrm{g} \mathrm{C} \mathrm{m}^{-3}$ (EMEP, 2011). All the high-EC-loading sites show an increase in the EC concentration during winter. These increased levels are likely to reflect both increased emissions (influence of wood burning emissions in winter), as well as meteorological conditions preventing dispersion of the air pollution by frequent temperature inversions and reduced boundary layer height. As for EC, the lowest levels of OC are observed in Scandinavia, Eastern Mediterranean sites and at certain high altitude sites $\left(0.6-1.8 \mu \mathrm{g} \mathrm{C} \mathrm{m}^{-3}\right)$ (EMEP, 2011). At sites in Eastern Europe, UK, and northern Italy, the annual mean OC concentration ranged from 2.3-6.8 $\mu \mathrm{g} \mathrm{C} \mathrm{m}^{-3}$. Typically the sites experiencing the lowest carbonaceous aerosol loading have higher levels during summer. Increased summer time concentrations of OC have typically been associated with formation of secondary organic aerosol (SOA), both from anthropogenic and natural precursor gases. It has also been shown that primary biological aerosol particles (PBAP) contribute to increased levels of OC in summer (Yttri et al., 2007, 2011a, b). In winter, biomass burning is usually the main source, with sizable additional contribution from fossil fuel combustion (Gelencser et al., 2007; Gilardoni et al., 2011).

Mineral dust is even more sparsely monitored than carbonaceous matter in Europe even though it typically constitute up to $5-20 \%$ of the ambient $\mathrm{PM}_{10}$ mass (Denier van der Gon et al., 2010). Dust outbreaks may greatly increase the ambient air levels of PM, especially in Southern Europe (Querol et al., 2009; Perrino et al., 2008). During dust outbreak events, the $\mathrm{PM}_{10}$ concentration may exceed the EU limit value of $50 \mu \mathrm{g} \mathrm{m}^{-3}$ for the daily mean concentration (Querol et al., 2009). In addition, dust from natural regional re-suspension, and a number of anthropogenic sources, including agricultural, industrial and construction sources may contribute significantly to the ambient $\mathrm{PM}_{10}$ levels in Europe (Putaud et al., 2010; Denier van der Gon et al., 2010). Putaud et al. (2010) also show that average contributions of mineral dust to $\mathrm{PM}_{10}$ and $\mathrm{PM}_{2.5}$ during the period 1996-2007 range from about $4 \%$ in the north-western regions to about $15 \%$ in southern Europe. In the Mediterranean specific study by Querol et al. (2009), they show that mineral dust is the major component of $\mathrm{PM}_{10}$ in both western and eastern parts of the region, with highest levels in the east $\left(38 \%\right.$ of $\left.\mathrm{PM}_{10}\right)$.

\subsection{Temporal trends in particulate matter concentrations}

24 EMEP sites have long term measurements of $\mathrm{PM}_{10}$ (9$13 \mathrm{yr}$ ) including the year 2009. Most sites have $11 \mathrm{yr}$ of observations, while Vorhegg (Austria) and Penausende (Spain) have $9 \mathrm{yr}$ of data. The longest time series of PM mass concentration data reported to EMEP goes back to 1996, and reveals large inter annual variations in the concentration levels reflecting meteorological variability. Selected time series of $\mathrm{PM}_{2.5}$ and $\mathrm{PM}_{10}$ are shown in Fig. 6.

In particular the year 2003 represented an extreme case with significantly higher levels compared to the rest of the period. Despite the inter-annual variability, there is a relatively clear overall decrease in the mass concentration at several sites. Trend analysis is performed as described in Sect. 2.1, for the period 2000-2009. Sites with data for at least nine of the ten years are included, 24 for $\mathrm{PM}_{10}$ and 13 for $\mathrm{PM}_{2.5}$ (Table 4). There is a statistically significant 


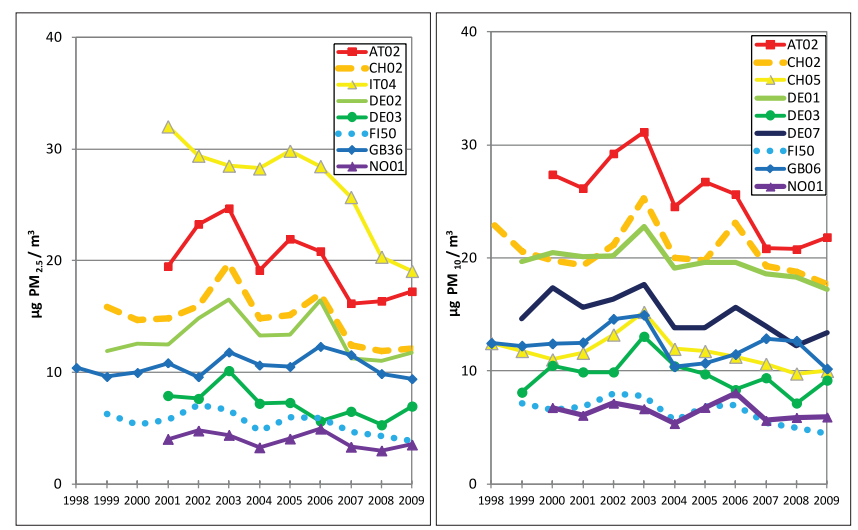

Fig. 6. Time series of $\mathrm{PM}_{2.5}$ (left) and $\mathrm{PM}_{10}$ (right) at selected EMEP sites.

decrease at about $50 \%$ of the sites in both size fractions, whereas none of the sites showed an increasing trend. The average reductions are $18 \%$ and $27 \%$ for $\mathrm{PM}_{10}$ and $\mathrm{PM}_{2.5}$ respectively, corresponding to an average change in mass of 2.9 and $3.7 \mu \mathrm{g} \mathrm{m}^{-3}$ over the same period. When considering the effect this may have on potential exceedances of limit values, it is worth noticing that the maximum reduction in absolute mass was $8 \mu \mathrm{g} \mathrm{m}^{-3}$ for $\mathrm{PM}_{10}$ at the Austrian site and as much as $11 \mu \mathrm{g} \mathrm{m}^{-3}$ for $\mathrm{PM}_{2.5}$ at the site in Northern Italy, while $6 \mu \mathrm{g} \mathrm{m}^{-3}$ reductions occurred at several other sites. The recent analysis on European PM trends (Barmpadimos et al., 2012) using selected EMEP data corrected by meteorological variability show similar results as those presented here.

The geographical distribution of the relative decrease in per cent (as given in Table 4) is shown in Fig. 7 for $\mathrm{PM}_{2.5}$ and $\mathrm{PM}_{10}$. The downward trend in the observed annual mean concentration of PM mass corresponds to the reported reduction in the emissions of primary PM and precursors to secondary PM during the actual period. The SIA precursors $\mathrm{SO}_{\mathrm{x}}, \mathrm{NO}_{\mathrm{x}}$ and $\mathrm{NH}_{3}$ have been reduced with $28 \%, 9 \%$ and $12 \%$ respectively in EMEP from 2000-2009 (EMEP/CEIP, 2011). Primary $\mathrm{PM}_{2.5}$ emissions have decreased by $20 \%$ in the same period (EMEP/CEIP, 2011). There is a tendency, though not very significant, that the $\mathrm{PM}_{2.5} / \mathrm{PM}_{10}$ ratio has decreased from 0.70 to 0.63 , indicating that the fine fraction may have decreased relatively more than the coarse fraction (Table 4).

It is more challenging to assess changes in the content of carbonaceous matter. Regular continuous measurements of EC/OC with a long-term goal started in 2001, and are available only at two stations across Europe (in Norway and Italy), and only the Norwegian site has data for EC/OC in both the $\mathrm{PM}_{10}$ and $\mathrm{PM}_{2.5}$ size fractions. Figure 8 presents the time series of EC and $\mathrm{OC}$ at the Norwegian site, indicating a slight reduction in concentrations, although there is a large interannual variability. Note that there was a change in the analytical protocol for EC/OC measurements in 2008.
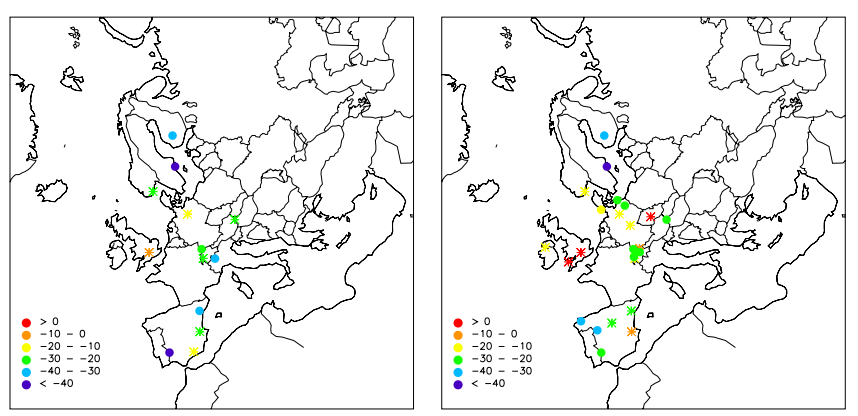

Fig. 7. Geographical distribution of the relative change in per cent in $\mathrm{PM}_{2.5}$ (left) and $\mathrm{PM}_{10}$ (right) in Europe over the $10 \mathrm{yr} 2000$ 2009. Unit: percent. Sites with no significant trends are shown with a cross, and negative numbers indicate a decrease.

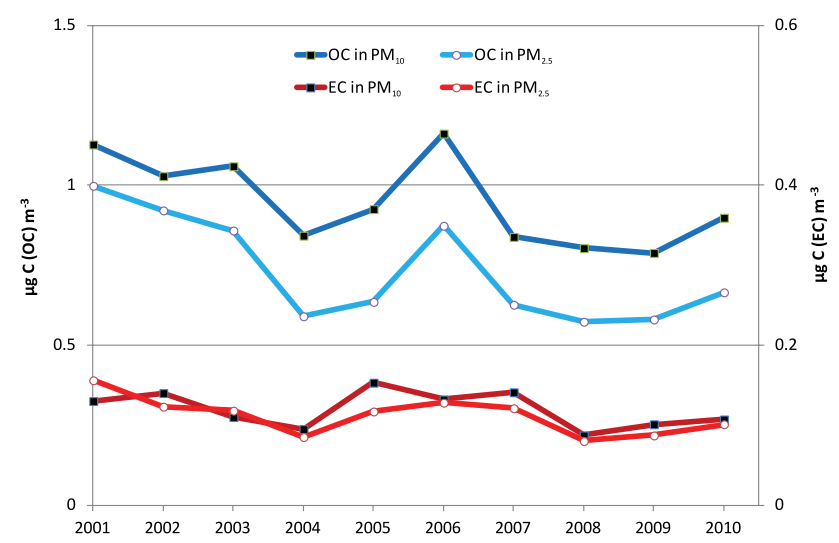

Fig. 8. Time series of $\mathrm{EC}$ and $\mathrm{OC}$ in $\mathrm{PM}_{2.5}$ and $\mathrm{PM}_{10}$ at Birkenes (NO01), Southern Norway.

Since there are no $\mathrm{PM}_{10}$ or $\mathrm{PM}_{2.5}$ measurements extending over decades, it is difficult to quantify the changes in mass for a longer time perspective. The measurement data on total suspended particulate matter (TSP) since 1977 show a large reduction in mass concentration. For the fourteen Swiss, German and Hungarian sites with data from 1980 to 1995 , the average mass decrease in TSP of $7 \mu \mathrm{g} \mathrm{m}^{-3}$ for the ten year period $1980-1990$ and $14 \mu \mathrm{g} \mathrm{m}^{-3}$ for the period 1980-1999 (data not shown). For major ions however, the observed chemical composition documents a change also in PM mass since 1980. The changes in mass derived from chemical composition data, shown in the major ions chapter above, indicate that the sulphate trend corresponds to a reduction of about $5 \mu \mathrm{g} \mathrm{m}^{-3}$. Trends in nitrogen since 1990 correspond to a reduction of about $1 \mu \mathrm{g} \mathrm{m}^{-3}$ for nitrate and $2 \mu \mathrm{g} \mathrm{m}^{-3}$ for ammonium. Despite the significant reductions in sulphur emissions, sulphate still remains one of the single most important compounds contributing to regional scale aerosol mass concentration. From an air quality perspective, this calls for even further measures towards decreased sulphur emissions to reduce aerosol loadings, even though there 
Table 4. Trend analysis of EMEP sites with $\mathrm{PM}_{10}$ and $\mathrm{PM}_{2.5}$ measurements from 2000-2009 (at some sites time series were initiated in 2001).

\begin{tabular}{lrrrrrrrr}
\hline & \# sites & \multicolumn{2}{c}{ Sites with sign. trend } & \multicolumn{2}{c}{ Per cent change } & \multicolumn{3}{c}{ Annual average conc. $\left(\mu \mathrm{\mu} \mathrm{m}^{-3}\right)$} \\
\cline { 2 - 8 } Comp & decrease & increase & Avg. & SD & $2000(1)$ & 2009 & change pr year \\
\hline \multicolumn{2}{l}{ Trends 2000(1)-2009 } & & & & & & & \\
\hline $\mathrm{PM}_{10}$ & 24 & $50 \%$ & $0 \%$ & $-18 \%$ & $13 \%$ & 16.4 & 13.5 & -0.29 \\
$\mathrm{PM}_{2.5}$ & 13 & $46 \%$ & $0 \%$ & $-27 \%$ & $12 \%$ & 13.2 & 9.5 & -0.37 \\
$\mathrm{PM}_{10}-\mathrm{PM}_{2.5}$ & 11 & $18 \%$ & $9 \%$ & $-4 \%$ & $24 \%$ & 4.97 & 4.87 & -0.01 \\
$\mathrm{PM}_{2.5} / \mathrm{PM}_{10}$ & 11 & $27 \%$ & $0 \%$ & $-9 \%$ & $9 \%$ & 0.70 & 0.63 & \\
\hline
\end{tabular}

are concerns that this may accelerate future warming because of the cooling effect of sulphate.

\section{Photooxidants and precursors}

\subsection{Introduction to ozone and precursor measurements}

Until the 1970s photochemical ozone pollution was mainly regarded as a local problem confined to certain regions characterized by heavy loads of pollution and a sunny and warm climate such as e.g. California. It was not until the beginning of the 1980s when ozone measurements from some European countries became available (Grennfelt and Schjoldager, 1984; Grennfelt et al., 1989), and when the first calculations with a preliminary EMEP model were made (Eliassen et al., 1982), that a potential large-scale ozone problem in Europe was demonstrated. Biologists have found indications of reduced growth and damages on plants due to the ambient ozone concentration level (e.g. Karlsson et al., 2004; Mills et al., 2011). In recent years, the role of ozone for climate has gained interest. Tropospheric ozone is the third most important anthropogenic greenhouse gas with a radiative forcing of about $0.35 \mathrm{~W} \mathrm{~m}^{-2}$ (Forster et al., 2007). This is around $20 \%$ of the forcing of $\mathrm{CO}_{2}$ since pre-industrial time. Ozone and aerosols are thus the main short-lived climate forcers.

Ozone measurements became part of the EMEP programme in EMEP's third phase (1984-1986), continuing the OECD programme OXIDATE (Grennfelt et al., 1989). The $1998 \mathrm{NO}_{\mathrm{x}}$ protocol was the first protocol to abate emissions of ozone precursors, although the original focus of that protocol was acid deposition. In the first years most of the ozone monitoring stations was located in the UK, the Nordic countries and central Europe (Germany, Switzerland and Austria). Gradually the network has expanded to the south and east. EMEP's monitoring programme for VOC was initiated in 1989. Regular measurements of light hydrocarbons (grab samples) and carbonyl compounds ( $8 \mathrm{~h}$ samples) started at a few European sites in 1992-1993. The monitoring network for VOC has changed considerably with time, and the number of sites has varied between 5 and 17 (Solberg et al., 2001).
Figure 9 shows the number of years with data for all the ozone and $\mathrm{NO}_{2}$ stations which have been in operation during the $20 \mathrm{yr}$ period 1990-2009. Clearly, certain parts of Europe are much better covered and have a significantly longer history than other parts. For ozone, the longest monitoring history is found in the UK, central Europe and the Nordic countries while a shorter history is seen in France and Spain. Few sites are located in the east and southeast part of the continent. For 2009, a total of 27 countries reported ozone data from 130 stations. The network for $\mathrm{NO}_{2}$ (Fig. 9) shows a somewhat better coverage in the southeast than for ozone, whereas the number of sites measuring VOC is much lower than for ozone and $\mathrm{NO}_{2}$ as seen by Fig. 10 .

The maps in Fig. 9 and Fig. 10 include all EMEP sites which have been in operation during the 20 yr period 19902009. Since the network has changed considerably with time, the station maps in Fig. 9 and Fig. 10 are not directly comparable to the present situation. Particularly for VOC the sites have changed with time. The present status (data for 2009) is that 11 sites perform measurements of light hydrocarbons and only 3 sites have carbonyl compounds, shown in Fig. 11.

All ozone measurements within EMEP are done by UV monitors following the guidelines in the EMEP manual. Information about the ozone data quality, calibration and maintenance procedures have been collected from the participants (Aas et al., 2001). Furthermore, questionnaires have been distributed to the countries requesting information about the routines for calibration and maintenance of the UV monitors. The most recent overview was compiled in 2007 and is available in electronic form on the EMEP web page: http: //www.nilu.no/projects/ccc/emepdata.html. The question of spatial representativity - recently discussed by Henne et al. (2010) - is, however, equally important as the operation of the instrument for ozone measurements. Ozone concentration near the ground is influenced by several factors, such as land use and topography, both affecting the surface dry deposition, as well as $\mathrm{NO}_{\mathrm{x}}$ sources in the vicinity leading to immediate ozone destruction. The importance of these processes normally varies through the day, following the diurnal cycle of the planetary boundary layer and the vertical mixing. Thus, the representativity of an ozone monitoring station 

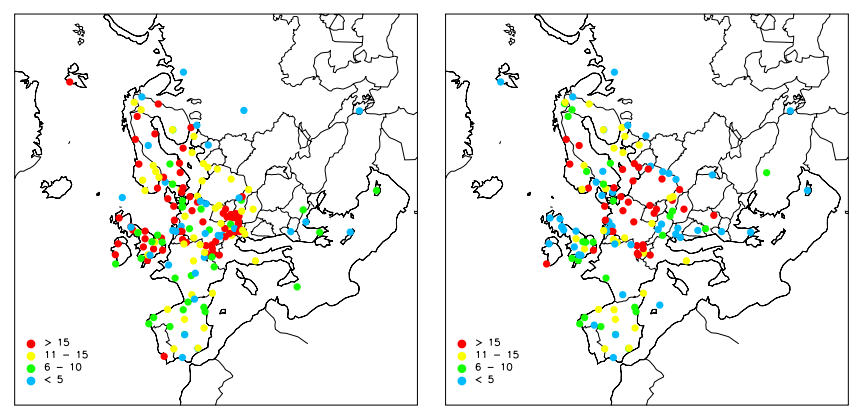

Fig. 9. Number of years with EMEP monitoring data during 19902009 for ozone (left) and $\mathrm{NO}_{2}$ (right).
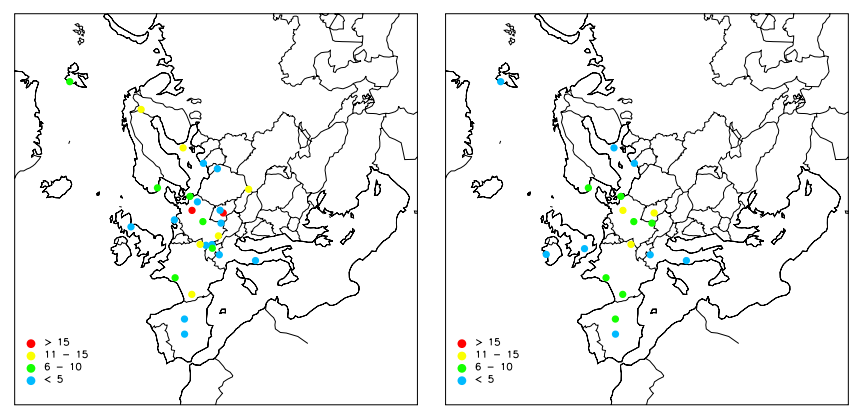

Fig. 10. Number of years with EMEP monitoring data during 19902009 for light hydrocarbons (left) and carbonyl compounds (right).

does not only depend on the distance to emission sources but also to the "inhomogeneity" of the surrounding area. Areas with strong gradients in topography and land use will lead to a poorer representativity of the ozone measurements than e.g. a flat desert.

Measurements of hydrocarbons are mostly done by canister grab samples followed by GC analyses in the laboratory. The samples are collected twice per week except for the French sites where they are collected once per week. At a few sites a continuous GC monitor at the station is used. Carbonyls are measured by sampling in DNPH (Dinitrophenylhydrazine) cartridges for $8 \mathrm{~h}$ (08:00-16:00 UT). As for the hydrocarbons, the carbonyls samples are collected twice per week. The QA procedures for the VOCs are described in the EMEP manual (EMEP/CCC, 2001) and technical details are given in the EMEP annual data reports (Solberg, 2011, and references therein). The measurements of VOCs and $\mathrm{NO}_{\mathrm{x}} / \mathrm{NO}_{\mathrm{y}}$ will be further developed within the frame of ACTRIS both with respect to frequency, harmonization of measurements and measurement protocols and number of sites.

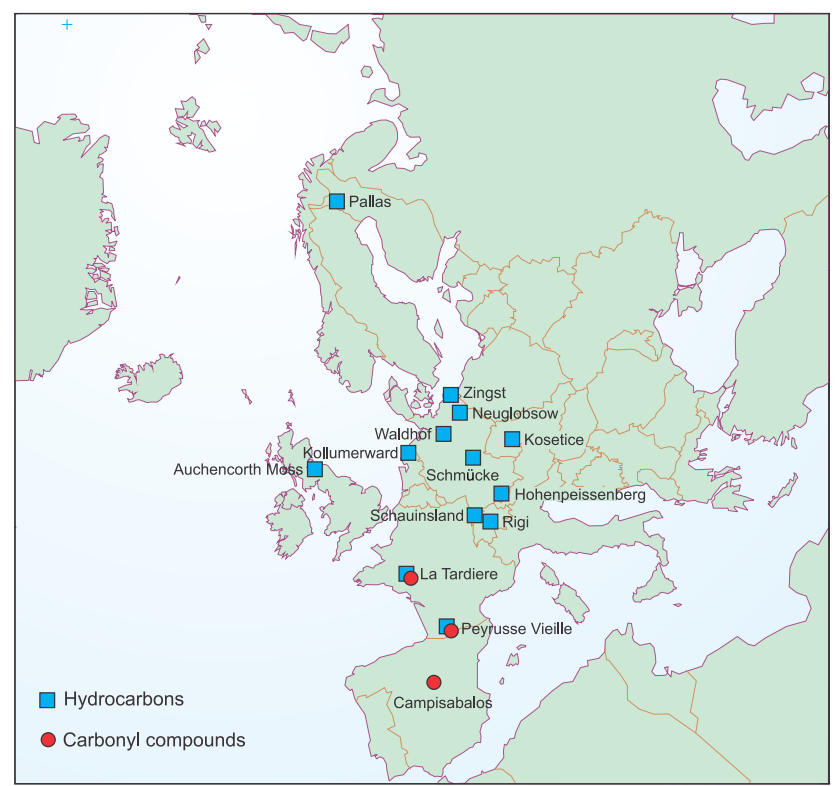

Fig. 11. The EMEP VOC monitoring stations in operation in 2009 (adopted from Solberg, 2011).

\subsection{Spatial distribution of ozone and precursors}

Surface ozone is closely linked to the meteorology. Thus, large regional differences are seen in Europe, reflecting different climate conditions. The conditions range from a polar climate in the far north to a moist marine climate in the western part to the warm, dry and sunny conditions in the south. Furthermore, the dominant westerly wind flow causes a gradual build-up of continental emissions and ozone as air moves across the continent. The topography of the Alps has a strong influence in that sites at different altitudes are exposed to very different ozone levels (Loibl et al., 1994), and sometimes the mixing between the boundary layer and the free troposphere act as an effective means of transporting manmade ozone and precursors from populated valleys into the free troposphere (Furger et al., 2000; Ordóñez et al., 2005). Already the EUROTRAC project TOR showed that there is a spatial gradient across Europe with ozone increasing from northwest to southeast in summer and an opposite gradient in winter (Scheel et al., 1997). This reflects the switch from $\mathrm{NO}_{\mathrm{x}}$ reducing ozone in winter to photochemical ozone formation in summer.

Five year mean values (2005-2009) of AOT40 (Accumulated exposure Over a Threshold concentration of $40 \mathrm{ppb}$ ) and summer 99 percentiles $\left(p_{99}\right)$ based on hourly EMEP ozone data for the summer half year are shown in Fig. 12. The AOT40 values shown here are based directly on the measurements which normally are taken at $2-3 \mathrm{~m}$ above ground. The correct AOT40 value to be used for the assessment of damage to crops should refer to $1 \mathrm{~m}$ above ground according to UNECE (see discussion in Simpson et al., 2007b). An 

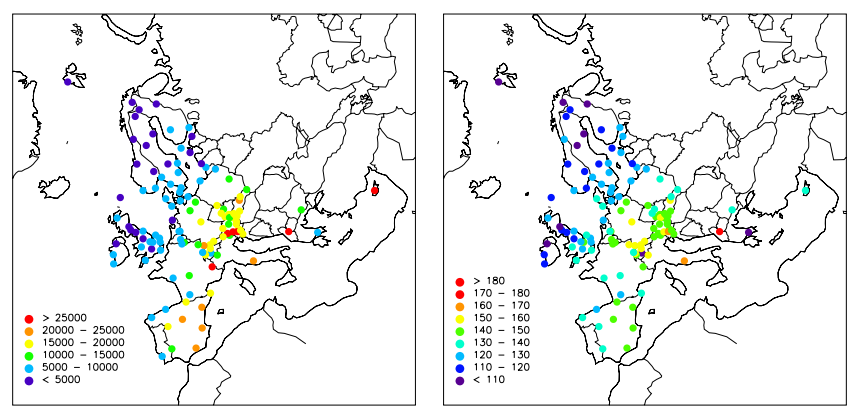

Fig. 12. Five years means of the 6-months AOT40 (left) and the 6months 99 percentile ( $p_{99}$ ) averaged over the years $2005-2009$. The summer half year (April-September) was used for both parameters. AOT40 values are in $\mathrm{ppb}$ h. The 99 percentiles are in $\mu \mathrm{g} \mathrm{m}^{-3}$.

increasing gradient is apparent from north to south for both parameters. Marked differences between the two parameters are also seen. While the highest $p_{99}$ values are confined to central Europe (Switzerland/Austria), high AOT40 values are seen also in Spain, south France and Crete. This could reflect that AOT40 is partly determined by the general background level at the actual latitude, whereas the $p_{99}$ values are more strongly linked to photochemical pollution episodes.

The number of EMEP VOC stations is too small to evaluate the geographical distribution in detail. Data show, however, that in winter when the photochemical oxidation is at a minimum, many of the hydrocarbons become fairly well mixed over Europe. Small spatial gradients in the winter median concentrations are seen for long-lived species such as ethane and propane (Fig. 13). The unsaturated alkenes are subject to oxidation by $\mathrm{O}_{3}$ also in winter and show clearer spatial differences also in that season.

\subsection{Long-term trends in ozone and precursors}

The issue of long-term trends in ozone has received increased attention during the last years. Many publications report an apparent mismatch between the trends in the anthropogenic emission of precursors and the observed trends (or lack of trends) in ozone (e.g. Colette et al., 2011; Wilson et al., 2012). The European anthropogenic emissions of $\mathrm{NO}_{\mathrm{x}}$ and NMVOC have been reduced by $31 \%$ and $46 \%$ (EMEP/CEIP, 2011), respectively, from 1990 to 2009. As these are the main precursors for ozone, one would expect clear changes in the European ozone concentration levels. However, due to the strong coupling between ozone and weather regimes and the substantial hemispherical background level, trends in ozone are often difficult to detect without very long time series. The recent study by Colette et al. (2011) showed very good agreement between observed and modelled $\mathrm{NO}_{\mathrm{x}}$ levels in $\mathrm{Eu}-$ rope, whereas they comment that "ozone trends turned out to be much more challenging to reproduce". Nevertheless, they found that the suite of models included in their work were able to capture the trends at the majority of the sites.

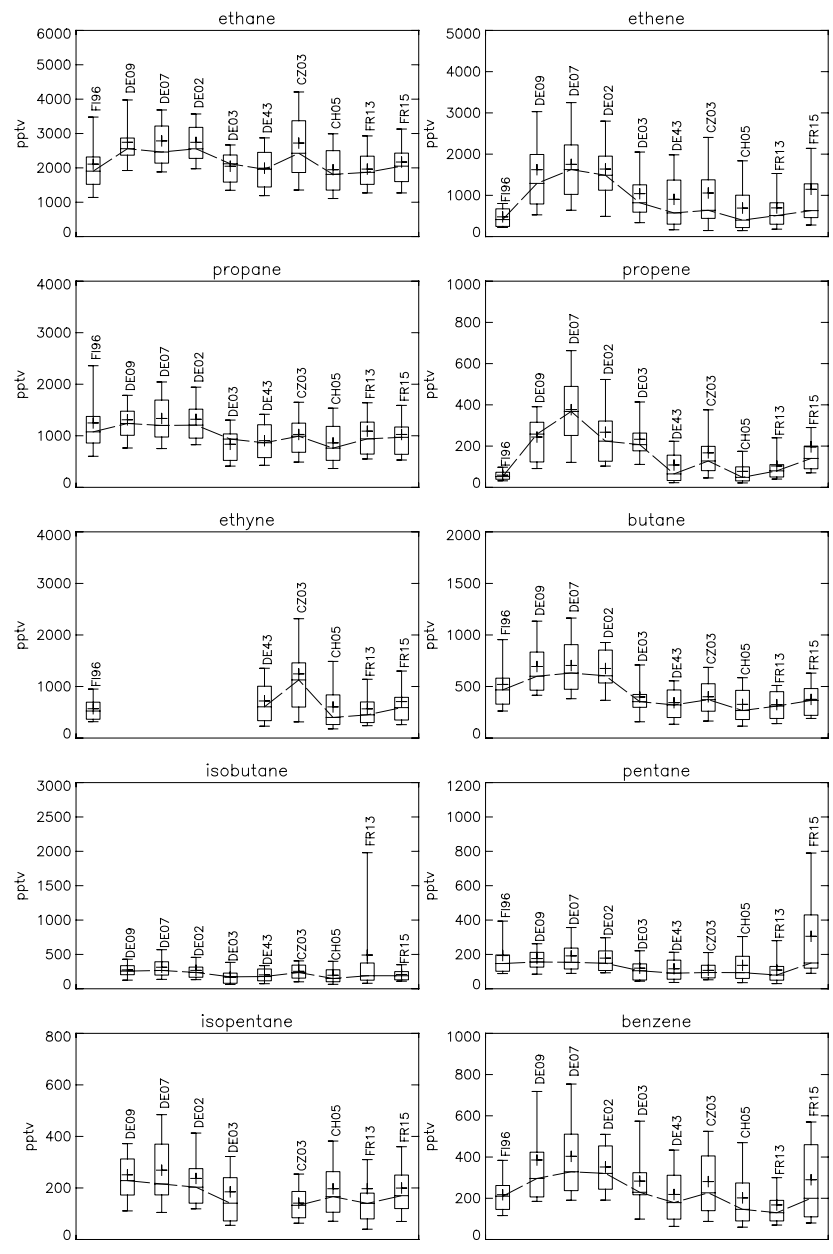

Fig. 13. Box- and whisker-diagrams for hydrocarbons measured at EMEP sites (Appendix A) satisfying the data requirements during winter 2009 (January, February, November, December). The markers indicate the 10-, 25-, 50-, 75- and 90-percentiles. Mean values are indicated by a cross. The dashed line connects the median values for clarity. Unit: $\operatorname{ppt}(\mathrm{v})$.

A recent study by the European Environment Agency (EEA) concluded that the reductions in emission of anthropogenic ozone precursors are not reflected in the observed annual average ozone concentrations, which do not show a downward trend in Europe between 1999 and 2009 (EEA, 2011). The study found that the number of exceedances of the $120 \mu \mathrm{g} \mathrm{m}^{-3}$ target value (8-h mean) went down in the years after 1992, but stabilized later. In a previous EEA study (EEA, 2009) trend analyses indicated significant reductions in ozone concentrations at British and Dutch stations (falling during the 1990s and levelling off thereafter). For the Austrian and Swiss stations, no significant trends were identified. The EEA, 2011 report used all the EEA sites, including urban and suburban ones. Its focus is on describing the current air quality situation and has less attention to addressing trends. The EEA ozone trend study of 2009 (EEA, 2009) used only 
sites classified as rural background in Airbase, and as a result of the fact that national agencies use their EMEP sites to also report for the European Commission Air Quality Directive, these datasets have a large overlap. No urban or suburban sites were included in the analysis and the study looked at single stations individually (mainly for the period 19952006) and included also results from regional scale photochemical modelling.

Smidt et al. (2010) found that at forest sites in Austria $\mathrm{SO}_{2}$ and $\mathrm{NO}_{\mathrm{x}}$ concentrations decreased after 1990 whereas no significant changes are seen in the ozone AOT40 values and 95-percentiles. Chevalier et al. (2007) looked at ozone data from the French EMEP network and from high mountain sites. They found no change in concentration levels at the station Pic-du-Midi (2877 m a.s.l.) since the early 1990s, while for some stations in the Alps they saw increasing ozone levels. Vautard et al. (2006) compared European EMEP ozone measurements for the period 1990-2002 with chemical transport model calculations. They found indications of reduced peak concentrations and an increase in the ozone baseline level. They argued that for central/northern Europe the emission reductions given in the official EMEP data may be too optimistic.

A study of long-term EMEP model and measurement data was published by Jonson et al. (2006). They also studied data from the period 1990 to 2002 and found a mixed picture for ozone. At most sites a downward trend in the 98 percentiles was found, but they comment that the inferred trends could be biased by the selection of start year. According to their analyses long-term ozone changes were a combined result of reduced precursor emissions and increased ozone background levels. The results indicated that the reductions in $\mathrm{NO}_{\mathrm{x}}$ emissions have been less effective in summer compared to winter. Solberg et al. (2005) analysed EMEP ozone measurements from the Nordic countries during the 1990s and estimated a reduction in the 99 percentiles of the order of $15 \mu \mathrm{g} \mathrm{m}^{-3}$ for southern Norway and southern Sweden. The scatter in the data was large, making the analysis uncertain, and according to the model results larger reductions should have occurred.

In general, long-term ozone trends at EMEP sites show a mixed pattern. Several studies report reduced peak concentrations, mainly during the 1990s, followed by stable ozone concentrations during the 2000s. Results depend critically on the parameter used in the statistical analyses (high percentile, annual mean, AOT40 etc.). Furthermore, the yearto-year variability in ozone due to varying meteorology is substantial, making it hard to separate the trends caused by reduced emissions from other effects. Thus, trend analyses based on measurement data alone is difficult and chemical transport model (CTM) calculations are often needed for the evaluation. Simpson et al. (1997) estimated that if one attempts to identify emission trends by the ozone monitoring data alone one would need of the order of $30 \mathrm{yr}$ of data. As noted by the EEA ozone trend study (EEA, 2009) the lack
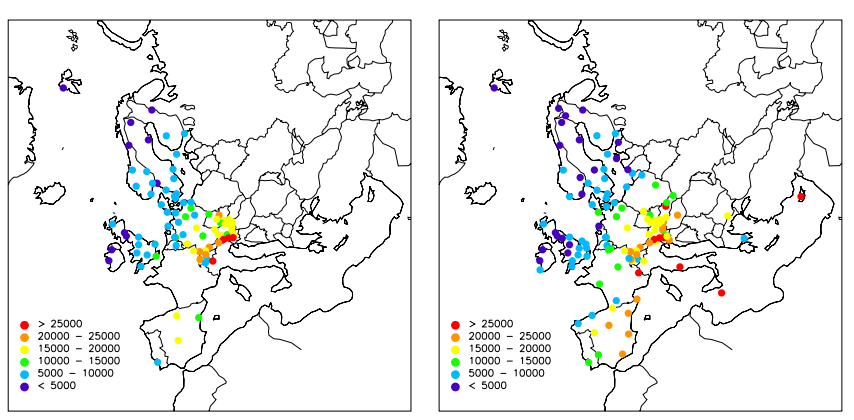

Fig. 14. Ten years mean of the 6-months' AOT40 (AprilSeptember) for the years 1990-1999 (left) and 2000-2009 (right). Unit: ppb h.
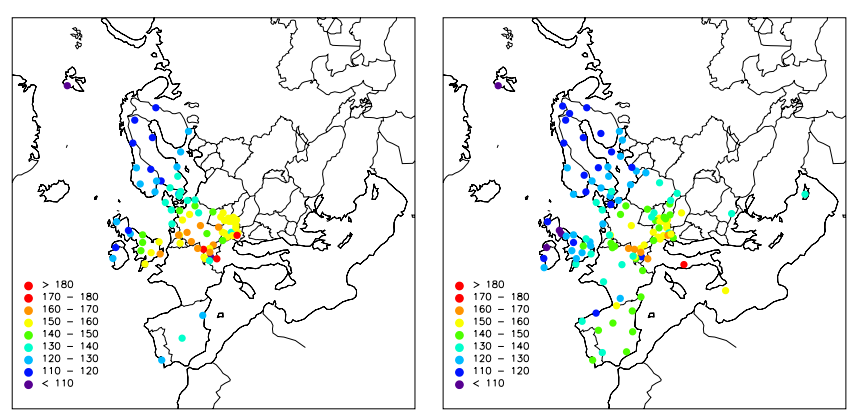

Fig. 15. Ten years mean of the annual 99 percentiles $\left(p_{99}\right)$ based on hourly data from the summer half year (April-September) for the years 1990-1999 (left) and 2000-2009 (right). Unit: $\mu \mathrm{g} \mathrm{m}^{-3}$.

of long-term ozone data is a major obstacle for identifying significant trends in Europe today.

Model runs are not included in the present work and to reduce the effect of inter-annual variability we have calculated 10-yr mean values for 1990-99 and 2000-2009, respectively. The length of the period is a compromise between climate variability ( $10 \mathrm{yr}$ is a short period in that sense) and emission change within the period.

Figures 14 and 15 show the results for the summer 6months AOT40 and 99 percentiles ( $p_{99}$ ), respectively. In large regions of the continent the change in monitoring network and lack of long-term data prevents any trend assessment. Many countries did not have ozone stations for a sufficient number of years during the 1990s while in other countries the station network has changed from the 1990s to the 2000s. Despite this, certain patterns are seen. The results indicate a clearer reduction in $p_{99}$ than in the AOT40. This is in line with the expectations, as AOT40 is highly sensitive to the general background level whereas the $p_{99}$ is more strongly linked to the number and extent of photochemical episodes. Reductions in the $p_{99}$ are seen in England, Benelux countries, Germany and the Czech Republic (Fig. 16). For Switzerland and Austria it is difficult to see any clear changes. A slight increase is seen in Spain, but the 

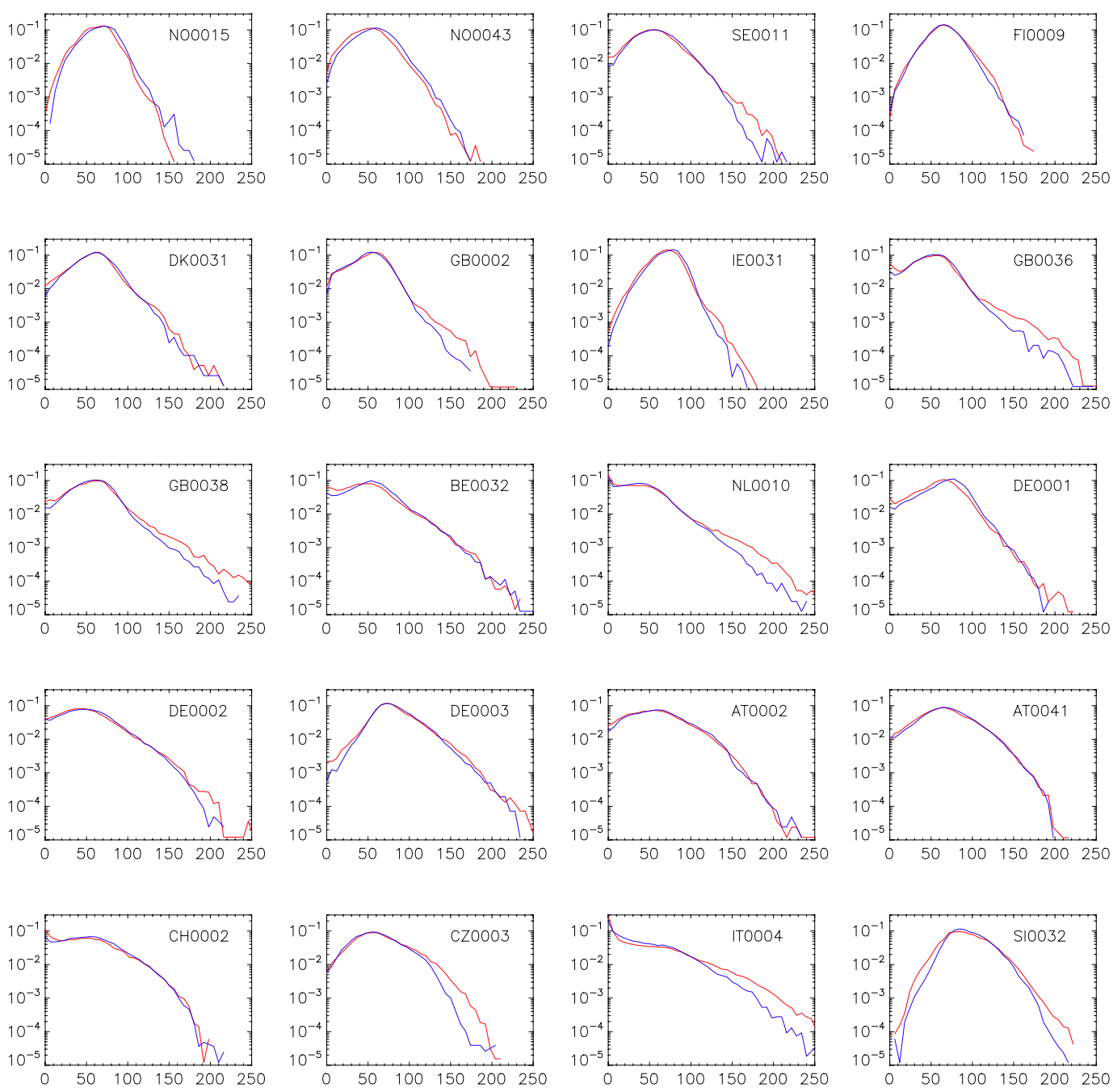

Fig. 16. Frequency distribution of hourly ozone concentrations for selected EMEP sites (Appendix A) (arranged by region from north to south) for the periods 1990-1999 (red) and 2000-2009 (blue). X-axis: $\mu \mathrm{g} \mathrm{m}^{-3}$, y-axis: frequency. Binsize: $6 \mu \mathrm{g} \mathrm{m}{ }^{-3}$.

change in station network makes it difficult to evaluate this further

The changes in AOT40 are smaller (Fig. 14). Reductions in England and Benelux countries are seen, whereas for other parts of the continent the pattern is more mixed. These results indicate fairly stable AOT40 values in Switzerland, Austria and the Czech Republic.

As mentioned above, the type of indicator (mean, percentile, AOT40, etc.) is critical for the estimated trend. The reason for this is that ozone is a secondary pollutant which depends on the emissions of VOC and $\mathrm{NO}_{\mathrm{x}}$ in a non-linear way. On a European scale, $\mathrm{NO}_{\mathrm{x}}$ acts as an ozone sink in winter and an ozone source in summer. Thus, reduced $\mathrm{NO}_{\mathrm{x}}$ emissions will lead to increased ozone in winter and reduced ozone in summer at rural background sites. At more polluted sites the $\mathrm{NO}_{\mathrm{x}}$ titration of ozone may last longer into the warm season and the switch from representing an ozone sink to rep- resenting an ozone source is more difficult to predict. Annual mean values are therefore of little value for evaluating ozone trends. Reduced $\mathrm{NO}_{\mathrm{x}}$ emissions should instead give rise to a narrower frequency distribution of ozone. The number of both the low and the high ozone concentrations should go down as explained above if the $\mathrm{NO}_{\mathrm{x}}$ emissions are reduced.

To look for such changes we have calculated the frequency distribution of hourly ozone concentrations based on the same two 10-yr periods as mentioned above (1990-1999 and 2000-2009). Figure 16 shows the distributions for selected stations which have a nearly complete 20 -yr time series. Unfortunately, not many sites have such a long monitoring history. There are more EMEP sites with sufficiently long time series than shown in Fig. 16, but we made a selection taking into account the geographical coverage to avoid e.g. a bias towards certain countries. 
The frequency plots show a mixed picture. For the Nordic countries the data indicate a slight reduction in the number of very low values. On the other hand, the highest percentiles are reduced at some Nordic sites and increased at others. A clear reduction in the highest values is apparent at Vavihill (SE0011) in southwest Sweden, whereas a very small change is seen at Prestebakke (NO0043) in southeast Norway. The reason for these differences is not clear.

The most pronounced change is seen at sites in the UK and the Netherlands, showing a reduction in the frequency of higher values. Also at Mace Head (IE0031) at the Irish west coast the data show a narrowing of the frequency distribution. Compared to this, surprisingly small changes are seen in Germany, Switzerland and Austria. For the two latter countries, no change is seen in the frequency distribution of ozone. At the German sites a slight reduction in the highest ozone values are found. The change is not large though, and applies only to the extreme right tail of the distribution. As opposed to this, a marked narrowing of the distribution is seen at Svratouch (CZ0001), Ispra (IT0004) and Krvavec (SI0032).

The reason why the changes in ozone frequency distribution vary that much across Europe is not clear. The results are, however, in line with the previously mentioned trend studies. The lack of change in ozone distribution at Swiss and Austrian sites is particularly surprising. These countries are located in central Europe and are receivers of pollutants from all directions. Thus, we would expect a clear signal of the reduced $\mathrm{NO}_{\mathrm{x}}$ and VOC emissions. The effect of the Alps causing a vertical mixing combined with a possible rise in the hemispheric ozone baseline level has been proposed as an explanation (e.g. Ordóñez et al., 2005). It has however not been proven that this effect is sufficiently large to completely counteract the effect of the reduced European emissions. A shift in the fleet of personal vehicles from petrol fuelled to diesel fuelled cars leading to an increased $\mathrm{NO}_{2} / \mathrm{NO}_{\mathrm{x}}$ emission ratio has also been proposed to contribute to a change in the photochemistry (Jenkin et al., 2008).

Figure 17 shows the differences in the measured percentiles as a function of the $p_{x}(2000 \mathrm{~s})$ for the same stations as in Fig. 16, i.e. $p_{x}(2000 \mathrm{~s})-p_{x}(1990 \mathrm{~s}), x=[1,10,50,90$, 95, 99, 99.5]. The results do show a slight increase in the lowest percentiles and a decrease in the high percentiles. It is only for the two extreme percentiles, $p_{99}$ and $p_{99.9}$, that a systematic reduction is seen, and even for these indicators we find increases at some sites. For $p_{95}$ there is no strong positive or negative bias for these stations when taken together. The annual median $\left(p_{50}\right)$ is increased at most of these sites.

It is important to keep in mind that the results in Figs. 16 and 17 are strongly biased by the selection of monitoring sites and should not be regarded as representative for the EMEP region in general. The sites cover only certain regions of the continent and for the east, southeast and southwest parts of Europe there are no sites with sufficiently long time series to carry out this analysis.

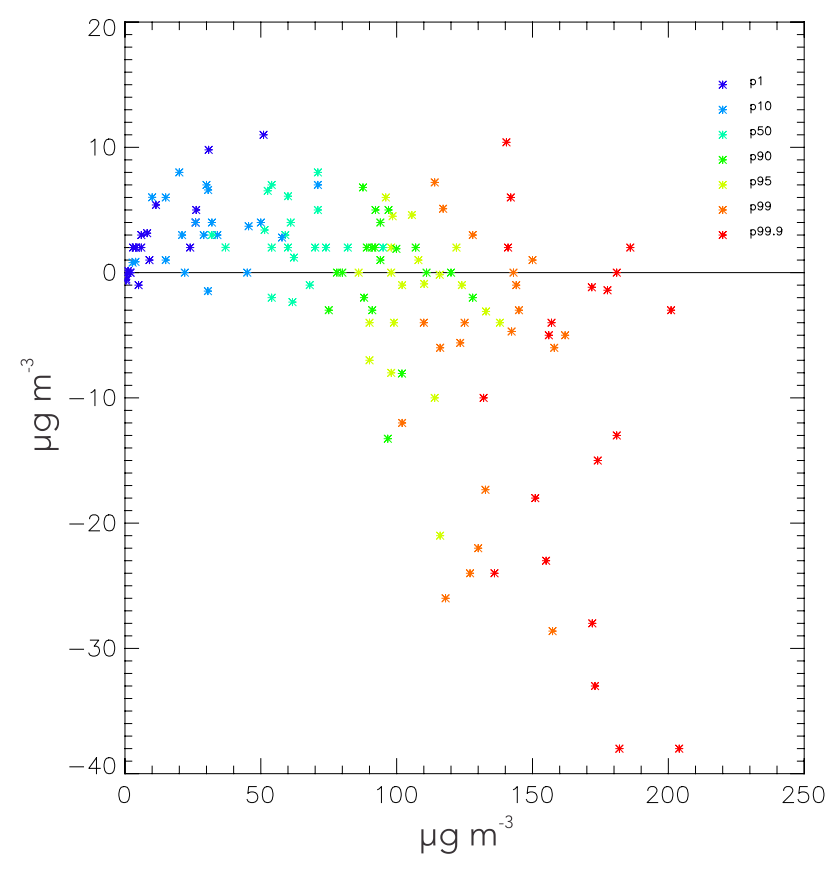

Fig. 17. The change in ozone percentiles from the 10 -yr period $1990-1999$ to $2000-2009$ as a function of the percentile values in 2000-2009 for the 20 stations shown in the previous figure. The color codes indicate the type of percentiles.

The lack of long-term running stations is a major obstacle also for studying trends in VOC at EMEP sites. The change in VOC network (change in stations and in measurement frequency) since the start of the programme in 1992-1993 reduces the number of sites suitable for trend studies to a minimum. Figure 18 shows the annual medians based on data from four winter months for the period 1995 to 2009. Note that the sampling frequency at FR0013 (Peyrusse Vieille) has been reduced from twice a week to once per week. The winter medians could be used as a proxy for the emission source strength, whereas in summer the oxidation by $\mathrm{OH}$ will mask the concentration levels at a varying degree, depending on the chemical life time.

The linear Sen trend slopes are shown in Table 5. The scatter in the data is large, and significant changes are only found for certain components/stations. Furthermore, no consistent picture is seen. While a marked decline is apparent for all compounds at Košetice (CZ0003), the other slopes are actually positive, indicating a rise in the concentrations.

\section{Heavy metals}

\subsection{Introduction to heavy metal observations}

Heavy metals are of major environmental concern due to their persistence, ability to bio-accumulate and their negative effect on human health and the environment (Pacyna et al., 
Table 5. Sen's non-parametric slope estimator of the annual trend [ppt $\mathrm{yr}^{-1}$ ] for measured light hydrocarbons. Only statistically significant trends are shown.

\begin{tabular}{|c|c|c|c|c|c|c|c|c|c|c|c|}
\hline & Years & ethane & ethene & ethyne & propane & Butane & isobutane & pentane & isopentane & benzene & toluene \\
\hline FI0096 & $96-09$ & & & & & & & & & & \\
\hline DE0002 & 1998-2009 & 68 & & & & & & & & & \\
\hline DE0008 & 2000-2009 & 174 & 70 & 58 & 81 & 32 & 17 & & & & \\
\hline CZ0003 & 1995-2009 & -33 & -94 & -83 & -32 & -21 & -10 & -9 & -17 & -22 & -16 \\
\hline FR0013 & 1999-2009 & & & & 71 & & 13 & & & & \\
\hline
\end{tabular}
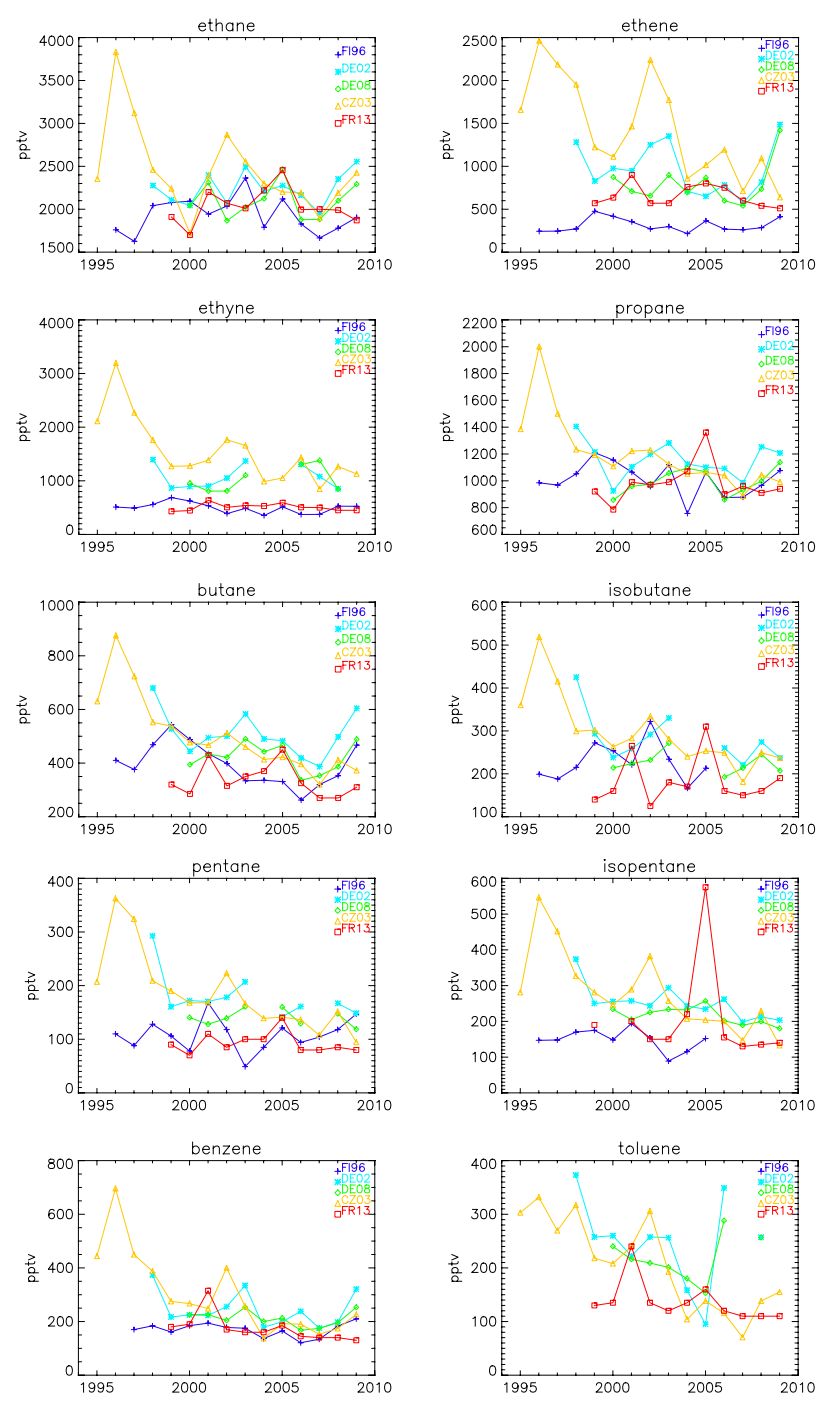

Fig. 18. Annual winter (January, February, November, December) median concentrations of hydrocarbons at Pallas (FI96), Waldhof (DE02), Schmücke (DE08), Košetice (CZ03) and Peyrusse Vieille (FR13) during the period 1995-2009 (from Solberg, 2011).
1984). Therefore regulation of these elements has been a priority both on a regional (CLRTAP) and global scale (UNEP). Heavy metals were included in EMEP's monitoring program in 1999. However, earlier data are available and have been included in the EMEP database. Thus, the database includes measurements back to 1976 for a few sites, although most of the time series start around 1990. During the seventh phase of EMEP (EB.AIR/GE.1/1998/8) it was recommended that the future work under the Convention should concentrate on eight priority elements: lead $(\mathrm{Pb})$, mercury $(\mathrm{Hg})$, cadmium $(\mathrm{Cd})$, chromium $(\mathrm{Cr})$, nickel $(\mathrm{Ni})$, zinc $(\mathrm{Zn})$, copper $(\mathrm{Cu})$ and arsenic (As), and particular attention was paid to the first three elements. The Aarhus Treaty, signed in 1998 by nearly all European countries, targets $\mathrm{Cd}, \mathrm{Pb}$ and $\mathrm{Hg}$ and committed the Parties to reduce their emissions for these three metals compared to 1990 .

Mercury differs from the other trace elements by having a longer residence time in the atmosphere, changing its chemical form (gaseous elemental mercury as well as reactive gaseous and particulate mercury), and having the possibility for re-emission to the atmosphere after deposition. Consequently, mercury has a higher potential for long-range transport. Mercury is therefore of a more global concern, and even though the European emissions have decreased during the last decades, the impact of increased Asian emissions are significant both in Europe and in the Arctic (UNEP, 2008; HTAP, 2010; AMAP, 2011).

To document and harmonise the analytical as well as the field procedures a joint working group consisting of representatives from HELCOM (Convention on the Protection of the Marine Environment of the Baltic Sea Area), EMEP, OSPARCOM (The Convention for the Protection of the marine Environment of the North-East Atlantic) and AMAP (Arctic Monitoring and Assessment Programme) initiated a plan for regular laboratory intercomparisons, starting in 1994 (Berg and Semb, 1996; Uggerud and Hjellbrekke, 2011a), and field intercomparison starting at Deuselbach in 1995 (Winkler and Roider, 1995). The EMEP methods are harmonized with air and deposition measurements defined in EU (EU, 1999, 2004, 2008; Aas et al., 2009; EMEP/CCC, 2001). There are several challenges with respect to data quality of the heavy metal measurements. Contamination of the samples is a large risk if the standard operating procedures 

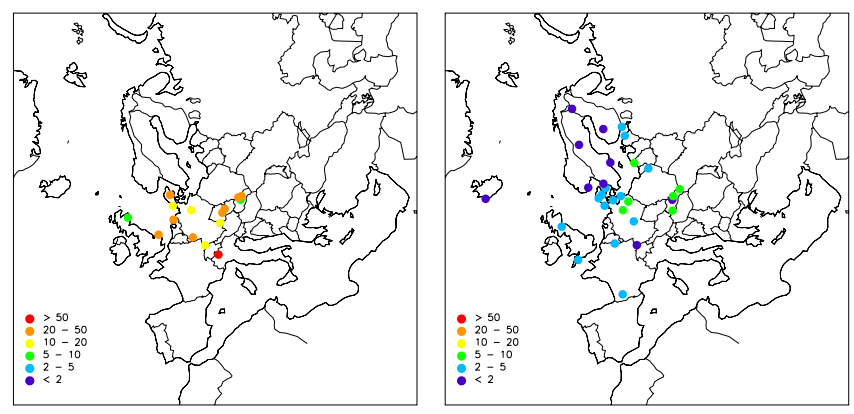

Fig. 19. Average concentrations of $\mathrm{Pb}$ in aerosols in 1990 and 2009 (unit $\mathrm{ng} \mathrm{Pb} \mathrm{m}^{-3}$ ).

are not followed (EMEP, 2001). Furthermore, the concentration levels are relatively low (especially in the last years) and the analytical methods used are not always adequate. A common problem is that the detection limit is often too high compared to the general concentration level at the site. Further, the data capture is also in general much poorer than e.g. for main components especially for components in air which are often sampled only one or two days a week.

\subsection{Heavy metals spatial distribution}

Maps showing the annual average concentrations of $\mathrm{Pb}$ and $\mathrm{Cd}$ in aerosols in 1990 and 2009 are presented in Fig. 19. The monitoring network has been extended to a larger area of Europe in the last decades. The obligations given by the EMEP monitoring strategy (UNECE, 2009) and EU's air quality directives (EU, 2004, 2008) have clearly improved the site coverage the last years, although there still is a lack of measurements in some parts of Europe. The Mediterranean region and the most eastern part of Europe are more or less lacking measurements of heavy metals. In $1990, \mathrm{~Pb}$ was measured at 42 sites. At only two of these sites were concurrent air and precipitation measurements carried out. In 2009, measurements of heavy metals in both air and precipitation were carried out at 36 sites. Totally 71 measurement sites for heavy metals were in operation. Mercury in either form (air or precipitation) was measured at 26 sites and 12 of these had data for both air and precipitation (Aas and Breivik, 2011).

The concentrations of heavy metals in air and precipitation resembles the emission distribution (see Pacyna et al., 2009) fairly well showing high values in Central Europe and lower concentrations in Northern Europe (Figs. 19 and 20). The lowest concentrations are generally observed in northern Scandinavia, Greenland, Iceland, and the westernmost part of Europe. The concentration and deposition levels increase to the southeast, but not homogeneously. Certain "hot spots" are seen for some elements. For $\mathrm{Pb}$ in precipitation, the highest levels in 2009 were observed in Italy and Hungary with concentrations exceeding $2 \mathrm{ngl}^{-1}$, while for $\mathrm{Pb}$ in aerosols the highest levels were observed in the Benelux countries and Slovakia where concentrations reached almost $10 \mathrm{ng} \mathrm{Pb} \mathrm{m}^{-3}$
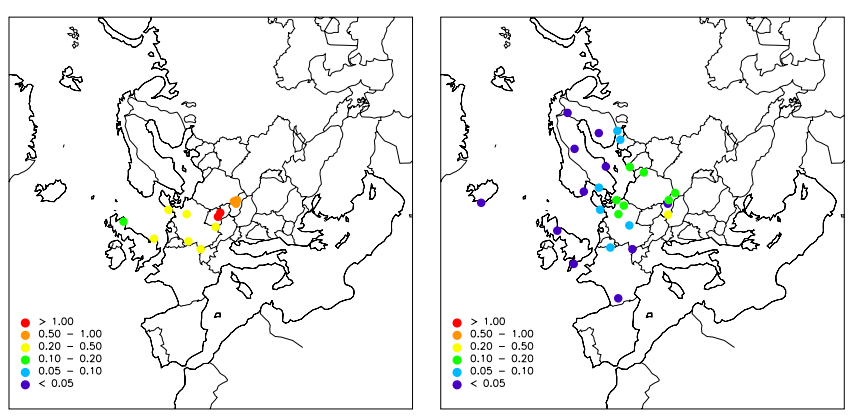

Fig. 20. Average concentrations of Cd in aerosols in 1990 and 2009 (unit ng $\mathrm{Cd} \mathrm{m}^{-3}$ ).

(Aas and Breivik, 2011). The lowest concentrations of $\mathrm{Pb}$ and Cd during 2009 were found in the Nordic countries and in Great Britain. The highest Cd levels in precipitation were found in Slovakia and the Czech Republic with concentrations around $0.2 \mathrm{ng} \mathrm{l}^{-1}$ while the highest levels in aerosols were observed in the Benelux countries and in Slovakia, with annual averages exceeding $0.2 \mathrm{ng} \mathrm{Cd} \mathrm{m}^{-3}$.

The spatial pattern of lead and cadmium is confirmed by the European moss surveys (Harmens et al., 2010). The lowest concentrations of metals in mosses are found in Scandinavia, the Baltic States and northern parts of the UK, while the highest concentrations are observed in Belgium and south-eastern Europe.

The spatial distribution of elemental $\mathrm{Hg}$ in air and precipitation does not follow the same pattern as the other heavy metals; the highest annual average in 2009 was observed in Sweden and the lowest in the UK and Eastern Europe. The reason why the $\mathrm{Hg}$ concentration pattern differs from the primary $\mathrm{Hg}$ emission pattern is that $\mathrm{Hg}$ has a long residence time in the atmosphere and also that re-emission from soil and ocean may affect more distant sites (e.g. Strode et al., 2007). The concentration distribution of $\mathrm{Hg}$ in aerosols show a more scattered pattern, but earlier studies have indicated high concentrations of total particulate Hg (TPM) near the source areas in Germany and lower towards the north (Wangberg et al., 2003; Munthe et al., 2003). For the other elements measured we refer to the annual EMEP data reports (e.g. Aas and Breivik, 2011).

\subsection{Heavy metals temporal trends}

The maps for 1990 and 2009 presented in Figs. 19 and 20 clearly show that the $\mathrm{Pb}$ and $\mathrm{Cd}$ concentrations in both air and precipitation have decreased during the last $20 \mathrm{yr}$. Figure 21 shows trend plots of $\mathrm{Cd}, \mathrm{Pb}$ and $\mathrm{Hg}$ in both air and precipitation from selected sites. Only Sweden has time series of Hg extending back to the early 1980s. The concentrations of $\mathrm{Pb}$ and $\mathrm{Cd}$ during the last two decades can be compared with the emission changes for these compounds (Table 6). The reductions in measured $\mathrm{Pb}$ are between $80 \%$ (in precipitation) and $90 \%$ (in aerosols). The emission reduction is in the same 
Table 6. Change in $\mathrm{Cd}$ and $\mathrm{Pb}$ concentrations in air and precipitation, compared to emission changes from 1990 through 2009.

\begin{tabular}{lrrrrrr}
\hline & No. of sites & \multicolumn{2}{l}{ Sites with significant trend } & \multicolumn{2}{l}{ Trends in conc. } & Emission \\
\cline { 3 - 7 } Comp & decrease & increase & Avg. & SD & trends \\
\hline Trends 1990-2009 & & & & & & \\
\hline Pb air & 11 & $100 \%$ & $0 \%$ & $-90 \%$ & $7 \%$ & $-84 \%$ \\
Pb precip. & 7 & $100 \%$ & $0 \%$ & $-80 \%$ & $22 \%$ & \\
Cd air & 8 & $100 \%$ & $0 \%$ & $-84 \%$ & $14 \%$ & $-54 \%$ \\
Cd precip. & 9 & $89 \%$ & $0 \%$ & $-64 \%$ & $53 \%$ & -54 \\
\hline
\end{tabular}

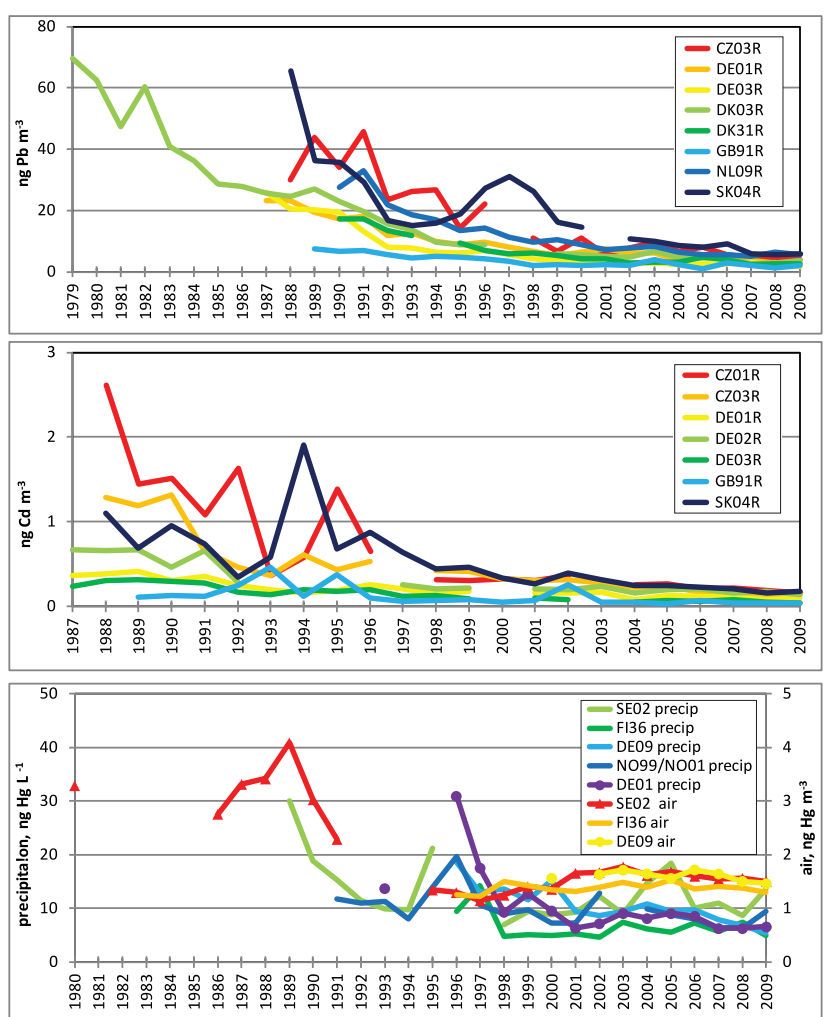

Fig. 21. Change of $\mathrm{Pb}$ (top) and $\mathrm{Cd}$ (middle) concentration in aerosol and mercury in air and precipitation (bottom) at selected EMEP stations. Note that it is not necessarily the same sites that have time series in both air and precipitation.

range (EMEP/CEIP, 2011), mainly due to the use of unleaded gasoline and the introduction of efficient dust-removal installations in industrial plants (Pacyna et al., 2007, 2009). The reduction in measured cadmium is also significant, between $64 \%$ (in precipitation) and $84 \%$ (in aerosols).

One should keep in mind that the sites with long term measurements are situated in central and Northern Europe, and that their average decrease may be higher than for the EMEP domain as a whole. The emission reduction of $\mathrm{Cd}$ in the EU15 countries is $68 \%$ compared to $54 \%$ for the whole region (EMEP/CEIP, 2011). In addition to the EMEP sites in central and Northern Europe, there are some additional sites with long term data confirming the large reduction of $\mathrm{Pb}$ and $\mathrm{Cd}$ in Europe. In a study based on measurements from the north-western Mediterranean Sea, a $90 \%$ decrease in the $\mathrm{Pb}$ concentrations in air between 1986 and 2008 was found. In the same study a reduction of $\mathrm{Cd}$ concentrations by $54 \%$ was found (Heimbürger et al., 2010). In a study measuring trace elements in mosses, the observed trend was similar to that shown from EMEP observation data, and with reductions in $\mathrm{Pb}$ and $\mathrm{Cd}$ levels by between 52 and $72 \%$ during the period from 1990 to 2005 (Harmens et al., 2010).

A major decline of the European $\mathrm{Hg}$ emissions occurred at the end of the 1980s and around 1990 (Pacyna et al 2009). Figure 21 indicates there are no major changes since 1990 and this is confirmed by a Mann-Kendall statistical test for both air and precipitation measurements. However, at the Swedish site with long term measurements of gaseous elemental mercury there has been a reduction of about $60 \%$ since 1980, and most of this occurred before 1992 (Fig. 21). In other studies a downward trend is found also for the $\mathrm{Hg}$ measurements in precipitation. Wängberg et al. (2007) observed a reduction in deposition between $10 \%$ and $30 \%$ when comparing the periods 1995-1998 and 1999-2002 for various sites in OSPARCOM/EMEP. However, the concentrations reveal a significant inter-annual variability and the choice of time period may determine if a trend is detected.

The measurements of total gaseous mercury (TGM) for the period from 1980 to about 1993, indicate a dramatic decrease of about $60 \%$ in ambient concentrations. Concentration changes reflect the emission change in Europe during the same period (EMEP/CEIP, 2011; Pacyna 2007, 2009). TGM has been monitored at the summit of the Wank Mountain in the Bavarian Alps in the first half of the nineties (Slemr and Scheel, 1998) and the decrease in concentrations was about $22 \%$ from 1990 to 1994 . Their study confirms the quite dramatic change in mercury emissions during this period on both regional and global scale. Reduced emissions in Europe and the long lifetime of $\mathrm{Hg}$ have resulted in an increased focus on non-European sources (HTAP, 2010). 


\section{Persistent organic pollutants}

\subsection{Introduction}

POPs are organic chemicals identified as being toxic, bioaccumulative, persistent and prone to long-range transport. Recognition of long-range atmospheric transport of POPs to remote areas such as the Arctic from the 1980s and onwards (e.g. Ottar, 1981; Wania and Mackay, 1993) contributed to the adoption of the Aarhus Protocol on POPs in 1998 and initially included 16 substances/substance groups. In 2009, seven additional substances were amended to the Protocol (ECE/EB.AIR/99/ADD.1). POPs in air and deposition have been reported to EMEP since 1999, yet the EMEP database now contains historical monitoring data from 1991 onwards (see Fig. 1).

For most other air pollutants covered by CLRTAP, concentrations in air tend to decline with distance from source regions due to dispersion, dilution, degradation and deposition (Wania, 1999). However, for some POPs, surprisingly high concentrations have been measured far from major emission regions (Wania, 1999). A characteristic feature of many POPs, unlike most other air pollutants, is their potential to undergo reversible atmospheric deposition (e.g. Larsson, 1985; Nizzetto et al., 2010). Therefore, air concentrations measured today might be caused by either recent primary atmospheric emissions or attributed to re-volatilization of these persistent and semi-volatile substances from contaminated surface reservoirs (soil, water, vegetation, snow, etc.) in contact with the atmosphere. This feature not only complicates predictions of source-receptor relationships (Malanichev et al., 2004), but is also an important factor to consider when interpreting air and deposition measurements, including spatial and temporal trends. This is also why complementary measurements of additional environmental surface media are desirable in the context of POP monitoring to better understand and predict air-surface exchange (e.g. Ruzickova et al., 2008). In the following, selected data from the EMEP database on POPs are presented, which both may serve to highlight some of the data contained therein as well as key features controlling the spatial and temporal trends of selected POPs in air. We refer to the literature for a more detailed account of EMEP data containing more detailed analyses of specific sites and/or contaminants (e.g. BrorströmLundén et al., 1994; Eckhardt et al., 2009; Dvorska et al., 2008; Holoubek et al., 2007; Hung et al., 2010; Wania and Haugen, 1999).

\subsection{Spatial patterns of selected POPs}

Although the number of POP monitoring stations has gradually increased over the last decade, the number of sites is still limited in terms of spatial coverage with stations mainly located in north-western Europe (Aas and Breivik, 2011). As an example of data contained in the EMEP database, Fig. 22

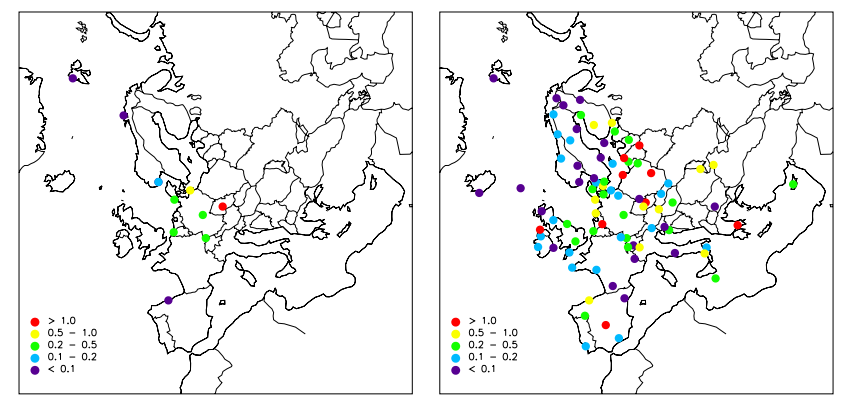

Fig. 22. Spatial patterns for pyrene in air (left) at EMEP stations in 2009, and (right) measured using passive air samplers across European background stations in 2006 (from Halse et al., 2011). Unit: ng $\mathrm{m}^{-3}$.

shows the spatial pattern of pyrene from EMEP sites in 2009. Pyrene belongs to the group of polycyclic aromatic hydrocarbons (PAHs), which are mainly formed during incomplete combustion of carbonaceous material (e.g. Breivik et al., 2007; Zhang and Tao, 2009). While PAHs also are subject to long-range atmospheric transport to remote areas (e.g. Halsall et al., 2001), model calculations indicate that their longrange atmospheric transport (LRT) potential is often more limited than that of many other legacy POPs (Beyer et al., 2003), which in turn suggest that a large spatial variability is to be expected - and indeed observed (Jaward et al., 2004b). Thus, the "true" spatial pattern for such contaminants may be difficult to rationalize based on a limited number of EMEP stations (Fig. 22a). To illustrate this, we also show the spatial pattern in European background air during the summer of 2006 in Fig. 22b, measured using passive air samplers (PAS) (Halse et al., 2011). PAS are cost-efficient sampling devices which typically integrate air concentrations over longer timeperiods (weeks, months, years) (Harner et al., 2006; Shoeib and Harner, 2002), and which have become popular both for temporal (Schuster et al., 2011) and spatial surveys (Pozo et al., 2009). From these data, it becomes evident that relative large differences in observed air concentrations of pyrene are measured between adjacent stations in e.g. central parts of Europe. Halse et al. (2011) found that the max/min ratio for measured air concentrations varied from $>380(\beta-\mathrm{HCH})$ to 5 (HCB), illustrating that what may be considered adequate spatial coverage for some POPs may not be sufficient for others. This study also included a direct comparison of PAS results with EMEP data, highlighting that coordinated PAS campaigns have the potential to serve as a valuable intercomparison resource, both within EMEP and beyond, which complements insights from interlaboratory intercomparisons alone (e.g. Su and Hung, 2010).

\subsection{Temporal trends of selected POPs}

Although the temporal coverage (sampling duration and frequency) of air measurements varies within the EMEP POPs 
measurement programme, all air measurements are carried out using active air sampling (AAS) techniques. To illustrate some of the EMEP POPs data that are available, we have plotted the long-term temporal trends of two hexachlorocyclohexanes (HCHs) in air from seven EMEP sites with long term measurements in Fig. 23. $\mathrm{HCH}$ is an insecticide which has seen extensive use world-wide ( $\mathrm{Li}, 1999)$, either as unpurified technical $\mathrm{HCH}(55-80 \% \alpha-\mathrm{HCH}, 8-15 \% \gamma-\mathrm{HCH})$ or as lindane ( $>99 \% \gamma-\mathrm{HCH}$ which is the isomer with insecticidal properties) (Breivik et al., 1999). In Europe, it has been estimated that 382000 tonnes of technical HCH and 81000 tonnes lindane were used between 1970 and 1996 (Breivik et al., 1999). HCH was also produced at several factories in Europe, but this has apparently ceased across the continent when production ended in Romania a few years ago (Vijgen et al., 2011). While the production and use of HCH may have peaked in the late 1960s/early 1970s and declined thereafter, the attention in recent years has increasingly shifted towards the problems associated with remaining stockpiles and wastes (Vijgen et al., 2011). As seen from Fig. 23 and as further confirmed by the statistical analysis in Table 7, both HCHs show a significant decrease in annual average air concentrations. Yet, there are also some notable differences in levels and patterns among these two isomers which deserve attention. As comparing and contrasting data from different laboratories is a complicating factor ( $\mathrm{Su}$ and Hung, 2010) when interpreting POP measurements from different sites, specific attention is given towards the longer time-trends from the Norwegian sites. Unlike Lista/Birkenes (NO99/NO01), the Zeppelin observatory (NO42) is located in the high Arctic at Spitsbergen. These Norwegian EMEP sites all show a fairly consistent decline in $\alpha-\mathrm{HCH}$ and $\gamma$ $\mathrm{HCH}$ over almost two decades. Furthermore, air concentrations of $\alpha-\mathrm{HCH}$ are also very similar at these Norwegian sites over the years (Fig. 23a). Still, there is a striking difference when comparing the divergent atmospheric concentrations of $\gamma-\mathrm{HCH}$ at Zeppelin versus those in southern Norway (Fig. 23b). While this could have something to do with different patterns of historical usage of technical HCH and lindane affecting these two stations (for which only technical $\mathrm{HCH}$ contains significant amounts of $\alpha-\mathrm{HCH}$ ), it is also seen as a reflection of differences in physical-chemical properties between different HCH isomers (Xiao et al., 2004). This is in turn expected to affect the LRT potential within the group of HCHs (Beyer et al., 2003; Li et al., 2002), with $\gamma$-HCH being more easily subject to wet deposition compared to $\alpha-\mathrm{HCH}$. $\alpha-\mathrm{HCH}$ is also seen as the isomer with a more significant potential for re-volatilization (Breivik and Wania, 2002; Harner et al., 1999). Thus, the example shown (Fig. 23) serves to illustrate that even for POPs having identical chemical formulas but different isomers, there may be significant differences in LRT behaviour.

Table 7 presents a trend analysis for selected POPs in precipitation and air during 1996-2009. Beyond including data for $\alpha$ - and $\gamma$-HCH previously introduced and discussed, we
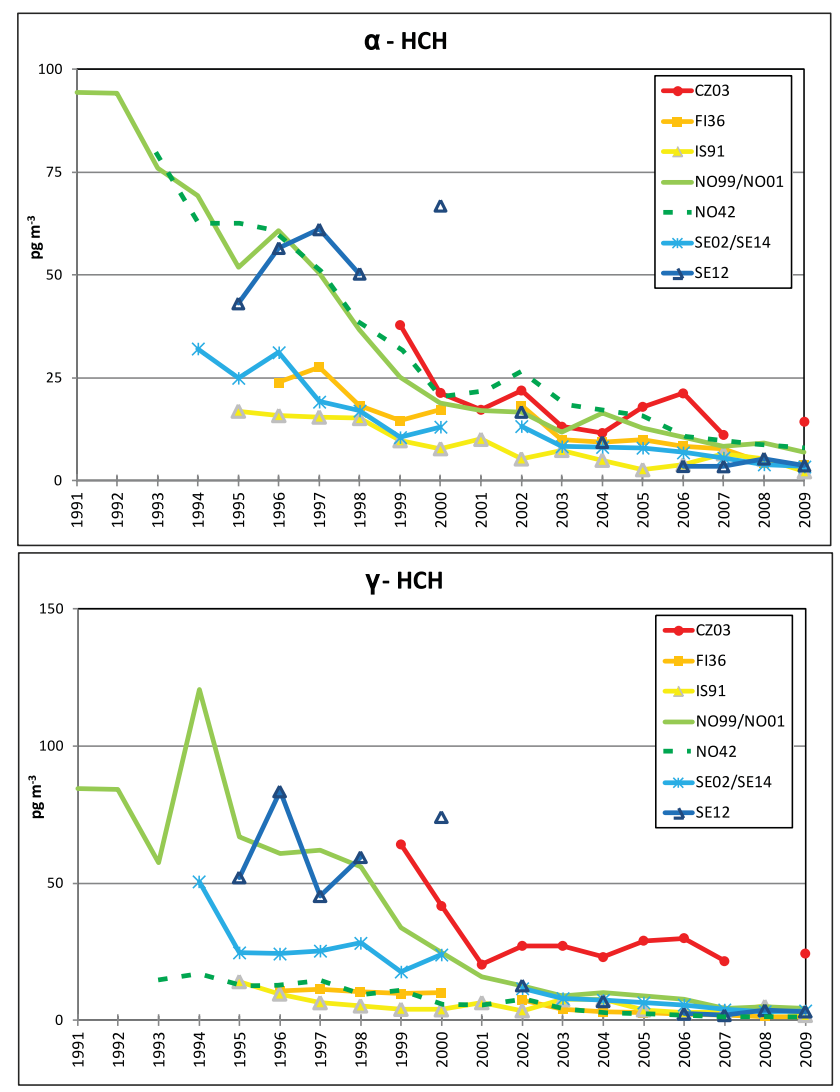

Fig. 23. Temporal trends in annual average air concentrations $\left(\mathrm{pg} \mathrm{m}^{-3}\right.$ ) for $\alpha-\mathrm{HCH}$ (top) and $\gamma-\mathrm{HCH}$ (bottom) at EMEP sites. Two sites located in the vicinity of each other both in Norway and Sweden are combined for trend analysis.

have included two PAHs (benzo[a]pyrene and pyrene) and three of the indicator polychlorinated biphenyls (PCBs: 28, 153 and 180). These substances belong to a group of 209 different industrial chemicals which were produced between 1930 and 1993 with a peak in $\sim 1970$ (Breivik et al., 2007). Finally, we have included hexachlorobenzene (HCB) in the trend analysis as a representative of POPs recognized as having miscellaneous sources (Barber et al., 2005). HCB is furthermore characterised by its elevated volatility compared to many legacy POPs combined with a long atmospheric half-life (Wania and Mackay, 1996), leading to a high atmospheric mobility and limited spatial variability in remote areas (Jaward et al., 2004a). From Table 7 we observe that each of these legacy POPs, whether measured in air or precipitation, all show a significant decline at one or more sites during the time period from 1996 to 2009 . However, this pattern is only consistent across all sites and both media for the HCHs. For the other compounds and compartments, there is always one or more site(s) not showing a significantly decreasing trend. For PCB-28 in precipitation, one of the sites (DE09) is even showing a significant increase which intuitively is hard to rationalize for a substance for which global production 
Table 7. Trend analysis for POPs in precipitation and air for the years 1996-2009 (bulk/wet only sampling at sites NO01, DE01, DE09, IS91 and NL91 and total deposition sampling at sites SE02, SE12 and FI36).

\begin{tabular}{|c|c|c|c|c|c|c|c|c|c|c|}
\hline \multirow[b]{3}{*}{ Comp } & \multicolumn{5}{|c|}{ POPs in precipitation or total deposition, 1996-2009 } & \multicolumn{5}{|c|}{ POPs in air, 1996-2009 } \\
\hline & \multicolumn{3}{|l|}{ No. of sites } & \multicolumn{2}{|c|}{ Trends in conc. } & \multirow{2}{*}{$\begin{array}{r}\text { No. of sites } \\
\text { total }\end{array}$} & \multirow[b]{2}{*}{ decrease } & \multirow[b]{2}{*}{ increase } & \multicolumn{2}{|c|}{ Trends in conc } \\
\hline & total & decrease & increase & Avg. & SD & & & & Avg. & SD \\
\hline Pyrene & 5 & 3 & 0 & $-53 \%$ & $33 \%$ & 4 & 1 & 0 & $-38 \%$ & $23 \%$ \\
\hline Benzo[a]pyrene & 5 & 2 & 0 & $-63 \%$ & $14 \%$ & 4 & 1 & 0 & $-36 \%$ & $39 \%$ \\
\hline PCB 153 & 6 & 1 & 0 & $-5 \%$ & $57 \%$ & 4 & 2 & 0 & $-31 \%$ & $34 \%$ \\
\hline PCB 28 & 6 & 4 & 1 & $-54 \%$ & $83 \%$ & 4 & 2 & 0 & $-45 \%$ & $14 \%$ \\
\hline PCB 180 & 6 & 1 & 0 & $-66 \%$ & $33 \%$ & 4 & 2 & 0 & $-57 \%$ & $28 \%$ \\
\hline$\alpha-\mathrm{HCH}$ & 7 & 7 & 0 & $-82 \%$ & $7 \%$ & 6 & 6 & 0 & $-84 \%$ & $5 \%$ \\
\hline$\gamma-\mathrm{HCH}$ & 8 & 8 & 0 & $-90 \%$ & $3 \%$ & 6 & 6 & 0 & $-87 \%$ & $8 \%$ \\
\hline $\mathrm{HCB}$ & 4 & 3 & 0 & $-72 \%$ & $13 \%$ & 3 & 1 & 0 & $-23 \%$ & $30 \%$ \\
\hline
\end{tabular}

started to decline four decades ago. PCB-28, which is among the more volatile and abundant PCBs, has also shown an apparent increase in Arctic air from 2003/2004 towards 2008. It has recently been proposed that enhanced re-volatilization of some POPs in the Arctic may be induced by climate change (Becker et al., 2008; Hung et al., 2010; Ma et al., 2011). Another striking feature is that annual average air concentrations of PCB-28 are consistently higher at Svalbard compared to Birkenes since 2004 (Aas and Breivik, 2011), which is somehow surprising given the remoteness of the Zeppelin station to industrialized and densely populated regions where elevated air concentrations of PCBs are typically observed (Jaward et al., 2004a). While further research is prudent to rule out local contamination at Zeppelin, it may also be viewed as a reflection of a potential enhanced influence from secondary sources in the Arctic. HCB displays a significant decrease at 3 out of 4 sites for which precipitation measurements are reported (Table 7). For air, only 1 out of 3 sites show a significant decrease. For some sites, air concentrations of HCB appear to be rather stable over the last decade and possibly somehow increasing at Zeppelin. According to Hung et al. (2010) an apparent increase in Arctic air concentration could be the result of an increase in global usage of pesticides contaminated with HCB.

\section{Conclusions and outlook}

The continuous monitoring of inorganic compounds in air and in precipitation, chemical, physical and optical properties of particulate matter, ozone, VOCs, heavy metals and persistent organic pollutants is fundamental to assess their impact on ecosystems, health and climate. Sulphur remains a major agent causing negative air quality impacts despite significant emission reductions during the three last decades. The monitoring of sulphur species is the most mature part of the EMEP monitoring programme, but still efforts are required to develop the monitoring across the EMEP domain.
The inclusion of new sites in the Eastern Europe, Caucasus and Central Asia (EECCA) region currently in development is a step in this direction. In other areas, and in particular in the Mediterranean and Eastern European region, additional sites operating at a daily time resolution are still needed. The situation for nitrogen monitoring is less mature compared to the situation for sulphur when it comes to air concentrations. Due to the heterogeneity in nitrogen concentrations, EMEP monitoring needs to be supplemented with finer scale monitoring applying low-cost methods. There is also a need to improve the situation with respect to sites which speciate the gas and particle phase of nitric acid + nitrate and ammonia + ammonium. The potential of new measurement techniques such as mini-AMS (Aas et al., 2012), PTRMS (Laj et al., 2009), MARGA (Schaap et al., 2011) etc. clearly offers new opportunities which EMEP could benefit from by inclusion as a level-2 activity rather than making measurements only during level-3 campaigns.

Surface ozone measurements have been a part of EMEP since the late 1980s. The ozone network has gradually expanded to the south and east. Ozone is substantially influenced by year-to-year variations in weather, and thus the data must cover a sufficient number of years for use in trend studies. The clearest trend signal for the period 1990-2009 is seen in the UK, Netherlands and some sites in the south and in the Czech Republic. These sites show reduced values at both tails of the frequency distribution (fewer low and high values). On the other hand, long time series from Switzerland and Austria do not reveal any trend in ozone. The reason for these regional differences in Europe is unclear. Monitoring of VOC started in 1992/93 in EMEP. The evaluation of longterm ozone trends is to a large extent limited by the availability of long-term VOC time series. Key challenges include the continuation of the longest ozone time series, and to expand the VOC- and methane monitoring programme further. The latter two objectives can be expected to have support from the efforts of research infrastructure projects ACTRIS (www. actris.net) and InGOS (http://www.ingos-infrastructure.eu/). 
The reductions in heavy metal emissions within Europe have been extensive, and the observation data clearly reflect these changes. The monitoring of heavy metals concentrations in precipitation is generally satisfactory, but fewer sites measure concentrations in air. For mercury, the European sources have been reduced significantly resulting in a relatively large contribution from non-European sources to ambient levels. The monitoring efforts within Europe have gradually improved in Northern Europe, while other regions have little data. Additional sites are clearly also needed outside the EMEP region.

Time-series for some POPs are now approaching two decades, yet challenges remain in deciphering the relative importance of primary and secondary emissions as well as the potential influence of processes related to climate change in controlling these time trends. However, complemented with independent data sets on POPs derived during specific campaigns by various research groups (e.g. Jaward et al., 2004a, b) and other relevant monitoring efforts within parts of Europe, such as the UK TOMPS programme (Toxic Organic Micro-pollutants Monitoring Network) (Schuster et al., 2010), MONET CEEC (Monitoring of persistent organic compounds in the air using the passive air sampling technique) in Central and Eastern Europe and MONARPOP (Monitoring Network in the Alpine Region for Persistent and other Organic Pollutants in the Alps) (Kaiser, 2009), the spatial coverage for many legacy POPs have recently been judged to be adequate (HTAP, 2010). Of vital importance to the improved understanding of spatial patterns in recent years have been the recent developments within passive air sampling (PAS) techniques (e.g. Harner et al., 2006; Ockenden et al., 1998) and their application at a variety of spatial scales. However, a major limitation of the PAS technique is that it only captures the gaseous fraction of POPs in air. Secondly, the uncertainty in back-calculated air concentrations derived on the basis of PAS relying on polyurethane foam disks has previously been estimated to be within a factor 2-3 (Gouin et al., 2005; Harner et al., 2006). Finally, information relevant to assess the short-term variability of air concentrations is lost using PAS techniques which integrate air concentrations over longer time periods. Hence, the active sampling techniques offering better temporal resolution which are encouraged under the EMEP programme remain essential for evaluating model predictions and to assess potential source regions controlling specific LRT events (Malanichev et al., 2004). For example, the use of active techniques was essential to identify the impact of biomass burning on air concentrations of PCBs in the Arctic (Eckhardt et al., 2007). There is nevertheless still potential for further development and improvement to the EMEP POPs programme, which in part also will depend on future scientific developments. Examples are (i) further assessment and improvement of QA/QC-protocols to ensure the comparability of data, and (ii) further development of sampling and analytical techniques of new POPs with divergent properties to the many legacy POPs that were initially included under the POP protocol.

EMEP has since it initiation based its work on consensus driven activities where national experts and nominated institutions have collaborated to address the transboundary aspects of air pollution. The activities have thus ranged from simple but robust monitoring to innovative and state-of-theart observations using new technologies. This synergy of operational and scientific activities has been very successful, and is a key basis element of the most recently adopted EMEP monitoring strategy (valid for the period 2010-2019). The national monitoring activity serves as a mechanism to involve national stakeholders and expertise also in the policy formulations. The Research Infrastructures activities of the European Commission Framework Programmes (EC-FP) have contributed to these efforts and have strengthened specific aspects of the EMEP monitoring programme significantly. Still, there are obvious challenges across the EMEP domain in maintaining and developing the monitoring activities. A particular concern is the observation that some countries are reducing their ambitions related to air quality issues. We note also that the financial basis for international collaborative research related to atmospheric composition research has been significantly reduced during the last years. During the period of existence of EMEP both national research programmes as well as EC-FP4 to EC-FP7 programmes have provided such opportunities. There is thus extensive documentation that long-term monitoring activities benefit from being supplemented by research programmes which can support in-depth analyses of data in combination with models and other tools. The tendency during the latter years is however an increased focus on other societal questions. We argue however that uncertainties in understanding the atmospheric composition changes are still large and that a strengthening of the area will yield improved climate, health and ecosystem research results and, thus, better guidance for environmental policy. 


\section{Appendix A}

Table A1. List of stations included in the trend analysis (for information about other sites presented on maps we refer to http://ebas.nilu.no).

\begin{tabular}{|c|c|c|c|c|}
\hline CODE & Station Name & Lat. & Long. & m a.s.l. \\
\hline AT0002R & Illmitz & $47^{\circ} 46^{\prime} 0^{\prime \prime} \mathrm{N}$ & $16^{\circ} 46^{\prime} 0^{\prime \prime} \mathrm{E}$ & 117 \\
\hline AT0041R & Haunsberg & $47^{\circ} 58^{\prime} 23^{\prime \prime} \mathrm{N}$ & $13^{\circ} 0^{\prime} 58^{\prime \prime} \mathrm{E}$ & 730 \\
\hline BE0032R & Eupen & $51^{\circ} 27^{\prime} 27^{\prime \prime} \mathrm{N}$ & $6^{\circ} 0^{\prime} 10^{\prime \prime} \mathrm{E}$ & 295 \\
\hline CH0002R & Payerne & $46^{\circ} 48^{\prime} 47^{\prime \prime} \mathrm{N}$ & $6^{\circ} 56^{\prime} 41^{\prime \prime} \mathrm{E}$ & 489 \\
\hline CH0005R & Rigi & $47^{\circ} 4^{\prime} 3^{\prime \prime} \mathrm{N}$ & $8^{\circ} 27^{\prime} 50^{\prime \prime} \mathrm{E}$ & 1031 \\
\hline CZ0001R & Svratouch & $49^{\circ} 44^{\prime} 0^{\prime \prime} \mathrm{N}$ & $16^{\circ} 3^{\prime} 0^{\prime \prime} \mathrm{E}$ & 737 \\
\hline CZ0003R & Košetice & $49^{\circ} 35^{\prime} 0^{\prime \prime} \mathrm{N}$ & $15^{\circ} 5^{\prime} 0^{\prime \prime} \mathrm{E}$ & 534 \\
\hline DE0001R & Westerland & $54^{\circ} 55^{\prime} 32^{\prime \prime} \mathrm{N}$ & $8^{\circ} 18^{\prime} 35^{\prime \prime} \mathrm{E}$ & 12 \\
\hline DE0002R & Langenbrügge & $52^{\circ} 48^{\prime} 8^{\prime \prime} \mathrm{N}$ & $10^{\circ} 45^{\prime} 34^{\prime \prime} \mathrm{E}$ & 74 \\
\hline DE0003R & Schauinsland & $47^{\circ} 54^{\prime} 53^{\prime \prime} \mathrm{N}$ & $7^{\circ} 54^{\prime} 31^{\prime \prime} \mathrm{E}$ & 1205 \\
\hline DE0007R & Neuglobsow & $53^{\circ} 10^{\prime} 0^{\prime \prime} \mathrm{N}$ & $13^{\circ} 2^{\prime} 0^{\prime \prime} \mathrm{E}$ & 62 \\
\hline DE0008R & Schmücke & $50^{\circ} 39^{\prime} 0^{\prime \prime} \mathrm{N}$ & $10^{\circ} 46^{\prime} 0^{\prime \prime} \mathrm{E}$ & 937 \\
\hline DE0009R & Zingst & $54^{\circ} 26^{\prime} 0^{\prime \prime} \mathrm{N}$ & $12^{\circ} 44^{\prime} 0^{\prime \prime} \mathrm{E}$ & 1 \\
\hline DE0043G & Hohenpeissenberg & $47^{\circ} 48^{\prime} 0^{\prime \prime} \mathrm{N}$ & $11^{\circ} 1^{\prime} 0^{\prime \prime} \mathrm{E}$ & 985 \\
\hline DK0003R & Tange & $56^{\circ} 21^{\prime} 0^{\prime \prime} \mathrm{N}$ & $9^{\circ} 36^{\prime} 0^{\prime \prime} \mathrm{E}$ & 13 \\
\hline DK0031R & Ulborg & $56^{\circ} 17^{\prime} 0^{\prime \prime} \mathrm{N}$ & $8^{\circ} 26^{\prime} 0^{\prime \prime} \mathrm{E}$ & 10 \\
\hline ES0009R & Campisábalos & $41^{\circ} 16^{\prime} 52^{\prime \prime} \mathrm{N}$ & $3^{\circ} 8^{\prime} 34^{\prime \prime} \mathrm{W}$ & 1360 \\
\hline FI0009R & Utö & $59^{\circ} 46^{\prime} 45^{\prime \prime} \mathrm{N}$ & $21^{\circ} 22^{\prime} 38^{\prime \prime} \mathrm{E}$ & 7 \\
\hline FI0036R & Pallas (Matorova) & $68^{\circ} 0^{\prime} 0^{\prime \prime} \mathrm{N}$ & $24^{\circ} 14^{\prime} 23^{\prime \prime} \mathrm{E}$ & 340 \\
\hline FI0050R & Hyytiälä & $61^{\circ} 51^{\prime} 0^{\prime \prime} \mathrm{N}$ & $24^{\circ} 17^{\prime} 0^{\prime \prime} \mathrm{E}$ & 181 \\
\hline FI0096G & Pallas (Sammaltunturi) & $68^{\circ} 0^{\prime} 0^{\prime \prime} \mathrm{N}$ & $24^{\circ} 9^{\prime} 0^{\prime \prime} \mathrm{E}$ & 340 \\
\hline FR0013R & Peyrusse Vieille & $43^{\circ} 37^{\prime} 0^{\prime \prime} \mathrm{N}$ & $0^{\circ} 11^{\prime} 0^{\prime \prime} \mathrm{E}$ & 200 \\
\hline FR0015R & La Tardière & $46^{\circ} 39^{\prime} 0^{\prime \prime} \mathrm{N}$ & $0^{\circ} 45^{\prime} 0^{\prime \prime} \mathrm{W}$ & 133 \\
\hline GB0002R & Eskdalemuir & $55^{\circ} 18^{\prime} 47^{\prime \prime} \mathrm{N}$ & $3^{\circ} 12^{\prime} 15^{\prime \prime} \mathrm{W}$ & 243 \\
\hline GB0006R & Lough Navar & $54^{\circ} 26^{\prime} 35^{\prime \prime} \mathrm{N}$ & $7^{\circ} 52^{\prime} 12^{\prime \prime} \mathrm{W}$ & 126 \\
\hline GB0036R & Harwell & $51^{\circ} 34^{\prime} 23^{\prime \prime} \mathrm{N}$ & $1^{\circ} 19^{\prime} 0^{\prime \prime} \mathrm{W}$ & 137 \\
\hline GB0038R & Lullington Heath & $50^{\circ} 47^{\prime} 34^{\prime \prime} \mathrm{N}$ & $0^{\circ} 10^{\prime} 46^{\prime \prime} \mathrm{E}$ & 120 \\
\hline GB0091R & Banchory & $57^{\circ} 4^{\prime} 36^{\prime \prime} \mathrm{N}$ & $2^{\circ} 32^{\prime} 4^{\prime \prime} \mathrm{W}$ & 120 \\
\hline IE0031R & Mace Head & $53^{\circ} 10^{\prime} 0^{\prime \prime} \mathrm{N}$ & $9^{\circ} 30^{\prime} 0^{\prime \prime} \mathrm{W}$ & 15 \\
\hline IS0091R & Storhofdi & $63^{\circ} 24^{\prime} 0^{\prime \prime} \mathrm{N}$ & $20^{\circ} 17^{\prime} 0^{\prime \prime} \mathrm{W}$ & 118 \\
\hline IT0004R & Ispra & $45^{\circ} 48^{\prime} 0^{\prime \prime} \mathrm{N}$ & $8^{\circ} 38^{\prime} 0^{\prime \prime} \mathrm{E}$ & 209 \\
\hline NL0009R & Kollumerwaard & $53^{\circ} 20^{\prime} 2^{\prime \prime} \mathrm{N}$ & $6^{\circ} 16^{\prime} 38^{\prime \prime} \mathrm{E}$ & 1 \\
\hline NL0010R & Vredepeel & $51^{\circ} 32^{\prime} 28^{\prime \prime} \mathrm{N}$ & $5^{\circ} 51^{\prime} 13^{\prime \prime} \mathrm{E}$ & 28 \\
\hline NO0001R & Birkenes & $58^{\circ} 23^{\prime} 0^{\prime \prime} \mathrm{N}$ & $8^{\circ} 15^{\prime} 0^{\prime \prime} \mathrm{E}$ & 190 \\
\hline NO0015R & Tustervatn & $65^{\circ} 50^{\prime} 0^{\prime \prime} \mathrm{N}$ & $13^{\circ} 55^{\prime} 0^{\prime \prime} \mathrm{E}$ & 439 \\
\hline NO0042G & Spitsbergen, Zeppelinfjell & $78^{\circ} 54^{\prime} 0^{\prime \prime} \mathrm{N}$ & $11^{\circ} 53^{\prime} 0^{\prime \prime} \mathrm{E}$ & 474 \\
\hline NO0043R & Prestebakke & $59^{\circ} 0^{\prime} 0^{\prime \prime} \mathrm{N}$ & $11^{\circ} 32^{\prime} 0^{\prime \prime} \mathrm{E}$ & 160 \\
\hline NO0099R & Lista & $58^{\circ} 6^{\prime} 0^{\prime \prime} \mathrm{N}$ & $6^{\circ} 34^{\prime} 0^{\prime \prime} \mathrm{E}$ & 13 \\
\hline SE0002R & Rörvik & $57^{\circ} 25^{\prime} 0^{\prime \prime} \mathrm{N}$ & $11^{\circ} 56^{\prime} 0^{\prime \prime} \mathrm{E}$ & 10 \\
\hline SE0011R & Vavihill & $56^{\circ} 1^{\prime} 0^{\prime \prime} \mathrm{N}$ & $13^{\circ} 9^{\prime} 0^{\prime \prime} \mathrm{E}$ & 175 \\
\hline SE0012R & Aspvreten & $58^{\circ} 48^{\prime} 0^{\prime \prime} \mathrm{N}$ & $17^{\circ} 23^{\prime} 0^{\prime \prime} \mathrm{E}$ & 20 \\
\hline SE0014R & Råö & $57^{\circ} 23^{\prime} 38^{\prime \prime} \mathrm{N}$ & $11^{\circ} 54^{\prime} 50^{\prime \prime} \mathrm{E}$ & 5 \\
\hline SI0032R & Krvavec & $46^{\circ} 17^{\prime} 58^{\prime \prime} \mathrm{N}$ & $14^{\circ} 32^{\prime} 19^{\prime \prime} \mathrm{E}$ & 1740 \\
\hline SK0004R & Stará Lesná & $49^{\circ} 9^{\prime} 0^{\prime \prime} \mathrm{N}$ & $20^{\circ} 17^{\prime} 0^{\prime \prime} \mathrm{E}$ & 808 \\
\hline
\end{tabular}




\section{Appendix B}

Table B1. Emission data used for trend analysis (from EMEP/CEIP, 2011).

\begin{tabular}{|c|c|c|c|c|c|c|c|c|c|c|c|c|c|c|c|c|}
\hline \multirow[b]{2}{*}{ Area/Year } & \multicolumn{4}{|c|}{$\mathrm{SO}_{\mathrm{x}}$} & \multicolumn{4}{|c|}{$\mathrm{NO}_{\mathrm{x}}$} & \multicolumn{4}{|c|}{ Nred } & \multicolumn{2}{|c|}{ PM } & \multicolumn{2}{|c|}{ NMVOC } \\
\hline & 1980 & 1990 & 2000 & 2009 & 1980 & 1990 & 2000 & 2009 & 1980 & 1990 & 2000 & 2009 & 2000 & 2009 & 1990 & 2009 \\
\hline Albania & 72 & 74 & 39 & 37 & 24 & 23 & 21 & 29 & 32 & 23 & 29 & 24 & 9 & 14 & 31 & 32 \\
\hline Armenia & 141 & 86 & 11 & 26 & 15 & 60 & 31 & 24 & 25 & 24 & 13 & 17 & 0 & 0 & 95 & 41 \\
\hline Austria & 360 & 74 & 32 & 21 & 246 & 212 & 206 & 187 & 52 & 69 & 65 & 64 & 23 & 20 & 284 & 123 \\
\hline Azerbaijan & 15 & 615 & 162 & 85 & 43 & 171 & 104 & 91 & 25 & 68 & 37 & 53 & 6 & 4 & 376 & 238 \\
\hline Belarus & 740 & 888 & 162 & 155 & 234 & 379 & 208 & 168 & 142 & 215 & 142 & 150 & 40 & 27 & 497 & 216 \\
\hline Belgium & 828 & 361 & 172 & 76 & 442 & 382 & 334 & 213 & 89 & 112 & 85 & 67 & 33 & 16 & 305 & 108 \\
\hline $\begin{array}{l}\text { Bosnia and } \\
\text { Herzegovina }\end{array}$ & 482 & 484 & 420 & 431 & 79 & 73 & 53 & 51 & 31 & 21 & 17 & 17 & 20 & 19 & 48 & 43 \\
\hline Bulgaria & 2050 & 2007 & 918 & 658 & 416 & 363 & 184 & 165 & 144 & 144 & 56 & 51 & 59 & 34 & 214 & 146 \\
\hline Croatia & 150 & 178 & 62 & 67 & 60 & 88 & 74 & 77 & 37 & 53 & 39 & 36 & 9 & 10 & 105 & 80 \\
\hline Cyprus & 28 & 46 & 46 & 17 & 13 & 19 & 22 & 19 & 8.5 & 5 & 6 & 5 & 4 & 2 & 16 & 11 \\
\hline Czech Republic & 2257 & 1876 & 264 & 173 & 937 & 742 & 321 & 251 & 156 & 157 & 74 & 73 & 28 & 20 & 374 & 151 \\
\hline Denmark & 452 & 176 & 29 & 15 & 307 & 266 & 201 & 132 & 138 & 134 & 93 & 77 & 22 & 24 & 166 & 95 \\
\hline Estonia & 287 & 274 & 97 & 55 & 70 & 74 & 37 & 29 & 24 & 26 & 10 & 10 & 21 & 19 & 71 & 36 \\
\hline Finland & 584 & 259 & 79 & 59 & 295 & 299 & 210 & 153 & 39 & 38 & 37 & 37 & 40 & 38 & 221 & 111 \\
\hline France & 3214 & 1333 & 632 & 303 & 2024 & 1829 & 1575 & 1117 & 795 & 787 & 802 & 744 & 381 & 270 & 2414 & 878 \\
\hline Georgia & 230 & 43 & 7 & 23 & 121 & 64 & 30 & 51 & 97 & 36 & 20 & 26 & 3 & 2 & 151 & 228 \\
\hline $\begin{array}{l}\text { Germany (DDR + } \\
\text { FRG merged) }\end{array}$ & 7514 & 5289 & 656 & 448 & 3334 & 2878 & 1911 & 1370 & 835 & 758 & 594 & 597 & 143 & 100 & 3584 & 1285 \\
\hline Greece & 400 & 487 & 493 & 427 & 306 & 299 & 328 & 375 & 79 & 79 & 74 & 63 & 49 & 63 & 281 & 212 \\
\hline Hungary & 1633 & 1011 & 486 & 80 & 273 & 276 & 185 & 167 & 157 & 124 & 71 & 68 & 26 & 28 & 252 & 128 \\
\hline Iceland & 18 & 9 & 35 & 74 & 21 & 9 & 27 & 24 & 3 & 4 & 4 & 4 & 1 & 0 & 12 & 6 \\
\hline Ireland & 222 & 186 & 140 & 33 & 73 & 119 & 138 & 90 & 112 & 114 & 121 & 108 & 12 & 9 & 111 & 52 \\
\hline Italy & 3440 & 1795 & 749 & 231 & 1585 & 1945 & 1431 & 981 & 441 & 405 & 449 & 391 & 179 & 144 & 2023 & 1107 \\
\hline \multicolumn{17}{|l|}{ Kazakhstan } \\
\hline Latvia & 96 & 97 & 16 & 4 & 83 & 69 & 36 & 29 & 38 & 47 & 13 & 16 & 23 & 28 & 73 & 61 \\
\hline Lithuania & 311 & 263 & 43 & 36 & 152 & 158 & 47 & 65 & 85 & 82 & 25 & 28 & 0 & 0 & & 0 \\
\hline Luxembourg & 24 & 26 & 2 & 3 & 23 & 20 & 16 & 19 & 7 & 7 & 7 & 4 & 17 & 10 & 136 & 70 \\
\hline Malta & $29^{\mathrm{a}}$ & 29 & 24 & 16 & $14^{\mathrm{a}}$ & 14 & 8 & 11 & $1^{\mathrm{a}}$ & 1 & 2 & 2 & 1 & 1 & 8 & 3 \\
\hline Netherlands & 490 & 189 & 73 & 38 & 583 & 549 & 395 & 276 & 234 & 249 & 163 & 125 & 24 & 16 & 491 & 154 \\
\hline Norway & 136 & 53 & 27 & 16 & 191 & 224 & 210 & 178 & 20 & 20 & 24 & 23 & 59 & 42 & 295 & 140 \\
\hline Poland & 4100 & 3278 & 1511 & 861 & 1229 & 1581 & 838 & 820 & 550 & 511 & 322 & 273 & 135 & 120 & 832 & 615 \\
\hline Portugal & 253 & 317 & 284 & 76 & 158 & 243 & 293 & 239 & 96 & 55 & 61 & 48 & 87 & 76 & 273 & 179 \\
\hline \multicolumn{16}{|l|}{ Moldova } & 36 \\
\hline Romania & 1055 & 1310 & 760 & 460 & 523 & 527 & 297 & 247 & 340 & 289 & 206 & 188 & 116 & 123 & 517 & 432 \\
\hline Russia $^{\mathrm{b}}$ & 7323 & 6113 & 2263 & $1723^{\mathrm{b}}$ & 3634 & 3600 & 2457 & $3350^{\mathrm{b}}$ & 1189 & 1204 & 663 & $602^{\mathrm{b}}$ & 0 & 0 & 0 & 0 \\
\hline \multicolumn{17}{|l|}{ Montenegro) } \\
\hline Slovakia & 780 & 542 & 127 & 64 & 197 & 215 & 107 & 86 & 63 & 66 & 32 & 25 & 23 & 28 & 122 & 65 \\
\hline Slovenia & 234 & 198 & 92 & 12 & 51 & 63 & 50 & 45 & 24 & 25 & 19 & 18 & 14 & 13 & 53 & 31 \\
\hline Spain & 2913 & 2166 & 1419 & 403 & 1068 & 1247 & 1277 & 946 & 285 & 329 & 377 & 354 & 95 & 73 & 1135 & 671 \\
\hline Sweden & 491 & 117 & 42 & 30 & 404 & 306 & 210 & 149 & 54 & 55 & 56 & 48 & 28 & 27 & 443 & 180 \\
\hline $\begin{array}{l}\text { Switzerland } \\
\text { Tajikistan }\end{array}$ & 116 & 42 & 18 & 13 & 170 & 156 & 107 & 78 & 77 & 68 & 66 & 64 & 12 & 10 & 262 & 91 \\
\hline TFYR & 107 & 110 & 90 & 113 & 39 & 46 & 39 & 33 & 17 & 15 & 14 & 7 & 9 & 9 & 21 & 28 \\
\hline Turkey & 1030 & 1519 & 2000 & 1557 & 364 & 691 & 1118 & 1278 & 321 & 373 & 402 & 409 & 305 & 247 & 636 & 1320 \\
\hline Turkmenistan & & & & & & & & & & & & & & & & \\
\hline Ukraine & 3849 & 3921 & 1599 & 1290 & 1145 & 1753 & 871 & 528 & 729 & 373 & 485 & 187 & 289 & 276 & 1053 & 275 \\
\hline United Kingdom & 4852 & 3699 & 1253 & 397 & 2580 & 2932 & 1789 & 1086 & 361 & 373 & 333 & 288 & 103 & 70 & 2396 & 826 \\
\hline $\begin{array}{l}\text { Uzbekistan } \\
\text { North Africa } \\
\text { Asian }\end{array}$ & & & & & & & & & & & & & & & & \\
\hline Baltic Sea & 228 & 168 & 188 & 122 & 352 & 236 & 276 & 327 & & & & & 22 & 17 & 8 & 13 \\
\hline Black Sea & 57 & 45 & 56 & 69 & 86 & 62 & 81 & 97 & & & & & 7 & 8 & 2 & 4 \\
\hline Mediterranean Sea & 1189 & 858 & 1070 & 1306 & 1639 & 1234 & 1564 & 1868 & & & & & 124 & 153 & 41 & 67 \\
\hline North Sea & 454 & 361 & 443 & 288 & 648 & 508 & 649 & 771 & & & & & 52 & 39 & 18 & 29 \\
\hline Remaining NE & 901 & 384 & 494 & 614 & 1266 & 565 & 723 & 858 & & & & & 58 & 71 & 19 & 30 \\
\hline Atlantic Ocean & & & & & & & & & & & & & & & & \\
\hline Natural marine & $743^{\mathrm{a}}$ & 743 & 743 & 743 & & & & & & & & & & & & \\
\hline Volcanic & $2000^{\mathrm{a}}$ & 2000 & 2000 & 2000 & & & & & & & & & & & & \\
\hline TOTAL & 59592 & 46863 & 22737 & 16368 & 27810 & 27865 & 21253 & 19318 & 8095 & 7673 & 6198 & 5478 & 2759 & 2366 & 20748 & 10777 \\
\hline sum Parties & 54020 & 42304 & 17743 & 11226 & 27786 & 27842 & 21232 & 15397 & 8095 & 7673 & 6198 & 5478 & 2497 & 2078 & 20659 & 10634 \\
\hline marine & 2829 & 1816 & 2251 & 2399 & 55581 & 55648 & 42454 & 3921 & & & & & 262 & 288 & 88 & 143 \\
\hline
\end{tabular}

a Data for 1980 not available, used 1990

$\mathrm{b}$ Emissions from Russia is sum of Kaliningrad, Kazakhstan in the former official EMEP domain; Kola/Karelia; St. Petersburg/Novgorod-Pskov; Rest of the Russian Federation. Not comparable dataset for 2009 , and used emissions from 2006 instead. 
Acknowledgements. We would like to express our thanks to all those who are involved in the EMEP monitoring efforts and have contributed through operating sites, performing chemical analysis and by submissions of data. This work was supported by the Co-operative Programme for Monitoring and Evaluation of the Long-range Transmission of Air pollutants in Europe (EMEP) under UNECE. We also thank the reviewers and the editor for valuable contributions to the paper.

Edited by: D. Simpson

\section{References}

Aas, W. and Breivik, K.: Heavy metals and POP measurements, 2009, Norwegian Institute for Air Research, Kjeller, EMEP/CCC-Report 3/2011, 2011.

Aas, W., Hjellbrekke, A.-G., Schaug, J., and Solberg, S.: Data quality 1999, quality assurance and field comparisons, Kjeller, Norwegian Institute for Air Research, EMEP/CCC Report 6/2001, 2001.

Aas, W., Hanssen, J. E., and Schaug, J.: Field intercomparison of main components in air in EMEP, Water Air Soil Poll. Focus, 1567-7230, 2007.

Aas, W., Alleman, L. Y., Bieber, E., Coleman, P., Gladtke, D., Houdret, J.-L., Karlsson, V., and Monies, C.: Comparison of methods for measuring atmospheric deposition of arsenic, cadmium, nickel and lead, J. Environ. Monit., 11, 1276-1283, 2009.

Aas, W., Tsyro, S., Bieber, E., Bergström, R., Ceburnis, D., Ellermann, T., Fagerli, H., Frölich, M., Gehrig, R., Makkonen, U., Nemitz, E., Otjes, R., Perez, N., Perrino, C., Prévôt, A. S. H., Putaud, J.-P., Simpson, D., Spindler, G., Vana, M., and Yttri, K. E.: Lessons learnt from the first EMEP intensive measurement periods, Atmos. Chem. Phys. Discuss., 12, 3731-3780, doi:10.5194/acpd-12-3731-2012, 2012.

AMAP Assessment 2011: Mercury in the Arctic. Arctic Monitoring and Assessment Programme (AMAP), Oslo, Norway. xiv + 193 pp., 2011.

Audrone, R. M.: Long-term trends of benzo(a)pyrene concentration on the eastern coast of the Baltic Sea, Atmos. Environ, 40, 20462057, doi:10.1016/j.atmosenv.2005.11.045, 2006.

Baldsano, J. M., Goncalves, M., and Jimenz, P.: A review of background air quality trends in Europe using EMEP data. Air pollution XIII, Thirteenth International Conference on Modelling, Monitoring and Management of Air Pollution, 82, 129-138, 2005.

Barber, J. L., Sweetman, A. J., van Wijk, D., and Jones, K. C.: Hexachlorobenzene in the global environment: Emissions, levels, distribution, trends and processes, Sci. Total Environ., 349, 1-44, 2005.

Barmpadimos, I., Keller, J., Oderbolz, D., Hueglin, C., and Prévôt, A. S. H.: One decade of parallel fine $\left(\mathrm{PM}_{2.5}\right)$ and coarse $\left(\mathrm{PM}_{10}-\mathrm{PM}_{2.5}\right)$ particulate matter measurements in Europe: trends and variability, Atmos. Chem. Phys., 12, 3189-3203, doi:10.5194/acp-12-3189-2012, 2012.

Becker, S., Halsall, C. J., Tych, W., Kallenborn, R., Su, Y., and Hung, H.: Long-term trends in atmospheric concentrations of alpha- and gamma-HCH in the Arctic provide insight into the effects of legislation and climatic fluctuations on contaminant levels, Atmos. Environ., 42, 8225-8233, 2008.
Berg, T. and Semb, A.: Preliminary results from the HELCOM - EMEP - PARCOM - AMAP analytical intercomparison of heavy metals in precipitation, Norwegian Institute for Air Research, Kjeller, EMEP/CCC-Note 1/95, 1995.

Beyer, A., Wania, F., Gouin, T., Mackay, D., and Matthies, M.: Temperature dependence of the characteristic travel distance, Environ. Sci. Technol., 37, 766-771, 2003.

Breivik, K. and Wania, F.: Mass budgets, pathways, and equilibrium states of two hexachlorocyclohexanes in the Baltic Sea environment, Environ. Sci. Technol., 36, 1024-1032, 2002.

Breivik, K., Pacyna, J. M., and Munch, J.: Use of alpha-, beta- and gamma-hexachlorocyclohexane in Europe, 1970-1996, Sci. Total Environ., 239, 151-163, 1999.

Breivik, K., Sweetman, A., Pacyna, J. M., and Jones, K. C.: Towards a global historical emission inventory for selected PCB congeners - A mass balance approach 3 An update, Sci. Total Environ., 377, 296-307, 2007.

Brorström-Lundén, E., Lindskog, A., and Mowrer, J.: Concentrations and fluxes of organic compounds in the atmosphere of the Swedish west coast, Atmos. Environ., 28, 3605-3615, 1994.

Cavalli, F. and Putaud, J. P.: Results of the 2010' intercomparison of TC, OC and EC analytical methods, in: Transboundary Particulate Matter in Europe: EMEP Status Report 2009, edited by: Yttri, K. E., Norwegian Institute for Air Research, Kjeller, EMEP Report 4/2011, 55-61, 2011.

Cavalli, F., Viana, M., Yttri, K. E., Genberg, J., and Putaud, J.-P.: Toward a standardised thermal-optical protocol for measuring atmospheric organic and elemental carbon: the EUSAAR protocol, Atmos. Meas. Tech., 3, 79-89, doi:10.5194/amt-3-79-2010, 2010.

CEN: Air Quality - Determination of the $\mathrm{PM}_{10}$ fraction of suspended particulate matter - Reference method and field test procedure to demonstrate reference equivalence of measurement methods, European Committee for Standardization, Brussels, CEN EN 12341:1998, 1999.

CEN: Standard gravimetric measurement method for the determination of the $\mathrm{PM}_{2.5}$ mass fraction of suspended particulate matter, European Committee for Standardization, Brussels, CEN EN 14907:2005, 2005.

Chevalier, A., Gheusi, F., Delmas, R., Ordóñez, C., Sarrat, C., Zbinden, R., Thouret, V., Athier, G., and Cousin, J.-M.: Influence of altitude on ozone levels and variability in the lower troposphere: a ground-based study for western Europe over the period 2001-2004, Atmos. Chem. Phys., 7, 4311-4326, doi:10.5194/acp-7-4311-2007, 2007.

Cofala, J., Amann, M., Heyes, C., Klimont, Z., Posch, M., Schöpp, W., Tarasson, L., Jonson, J., Whall, C., and Stavrakaki, A.: Final Report: Analysis of Policy Measures to Reduce Ship Emissions in the Context of the Revision of the National Emissions Ceilings Directive, March 2007, International Institute for Applied Systems Analysis, Laxenburg, Austria, 74 pp., 2007.

Colette, A., Granier, C., Hodnebrog, Ø., Jakobs, H., Maurizi, A., Nyiri, A., Bessagnet, B., D’Angiola, A., D’Isidoro, M., Gauss, M., Meleux, F., Memmesheimer, M., Mieville, A., Rouil, L., Russo, F., Solberg, S., Stordal, F., and Tampieri, F.: Air quality trends in Europe over the past decade: a first multi-model assessment, Atmos. Chem. Phys., 11, 11657-11678, doi:10.5194/acp11-11657-2011, 2011. 
Dayan, U. and Lamb, D.: Global and synoptic-scale weather patterns controlling wet atmospheric deposition over central Europe, Atmos. Environ., 39, 521-533, doi:10.1016/j.atmosenv.2004.09.063, 2005.

Denier van der Gon, H., Jozwicka, M., Hendriks, E., Gondwe, M., and Martijn Schaap, M.: Mineral Dust as a component of Particulate Matter, 78 pp., TNO Report 500099003, ECN, Bilthoven, The Netherlands, 2010

Dore, A. J., Vieno, M., Tang, Y. S., Dragosits, U., Dosio, A., Weston, K. J., and Sutton, M. A.: Modelling the atmospheric transport and deposition of sulphur and nitrogen over the United Kingdom and assessment of the influence of $\mathrm{SO}_{2}$ emissions from international shipping, Atmos. Environ., 41, 2355-2367, 2007.

Dvorska, A., Lammel, G., Klanova, J., and Holoubek, I.: Košetice, Czech Republic - ten years of air pollution monitoring and four years of evaluating the origin of persistent organic pollutants, Environ. Pollut., 156, 403-408, 2008.

Eckhardt, S., Breivik, K., Manø, S., and Stohl, A.: Record high peaks in PCB concentrations in the Arctic atmosphere due to long-range transport of biomass burning emissions, Atmos. Chem. Phys., 7, 4527-4536, doi:10.5194/acp-7-4527-2007, 2007.

Eckhardt, S., Breivik, K., Li, Y. F., Manø, S., and Stohl, A.: Source regions of some persistent organic pollutants measured in the atmosphere at Birkenes, Norway, Atmos. Chem. Phys., 9, 65976610, doi:10.5194/acp-9-6597-2009, 2009.

EEA: Assessment of ground-level ozone in EEA member countries, with a focus on long-term trends, European Environment Agency, Copenhagen, EEA Technical Report No. 7/2009, 2009.

EEA: Air quality in Europe - 2011 report, European Environment Agency, Copenhagen, EEA Technical Report No. 12/2011, 2011.

Egnèr, H., Brodin, G., and Johansson, O.: Sampling technique and chemical examination of air and precipitation, Kungl. Lantbrukshögskolans Annaler, 22, 369-410, 1955.

EMEP/CCC: Manual for sampling and chemical analysis, Norwegian Institute for Air Research, Kjeller, EMEP/CCC Report 1/95 (Last rev. 2001), http://tarantula.nilu.no/projects/ccc/ manual/index.html [2011-08-30], 2001.

EMEP-WMO: Workshop on Strategies for Monitoring of Regional Air Pollution in relation to the need within EMEP, GAW and other international bodies, Aspenäs Herrgård, Lerum, Sweden, 2-4 June 1997, edited by: Schaug, J. and Uhse, K., Kjeller, Norwegian Institute for Air Research, EMEP/CCC-Report 10/97, 1997.

EMEP-WMO: EMEP-WMO workshop on fine particles - emissions, modelling and measurements, Interlaken, Switzerland 2225 November 1999, edited by: Hanssen, J. E., Ballaman, R., and Gehrig, R., Kjeller, Norwegian Institute for Air Research, EMEP/CCC-Report 9/2000, 2000.

EMEP: Transboundary Particulate Matter in Europe: EMEP Status Report 2009, edited by: Yttri, K. E., Kjeller, Norwegian Institute for Air Research, EMEP Report 4/2011, 2011.

EMEP/CEIP: Emission data downloaded from WebDab in November 2011, http://www.ceip.at/emission-data-webdab/ emissions-as-used-in-emep-models/, 2011.

Eliassen, A.: The OECD study of long range transport of air pollutants: long-range transport modeling, Atmos. Environ., 12, 479$487,1978$.
Eliassen, A., Saltbones, J., Stordal, F., Hov, Ø., and Isaksen, I. S. A.: A Lagrangian Long-Range Transport Model with Atmospheric Boundary Layer Chemistry, J. Appl. Meteor., 21, 1645-1661, 1982.

EU: Council Directive 1999/30/EC of 22 April 1999 relating to limit values for sulphur dioxide, nitrogen dioxide and oxides of nitrogen, particulate matter and lead in ambient air, Off. J. Eur. Comm., L 163, 29/06/1999, 0041 - 0060, 1999.

EU: Directive 2004/107/EC of the European Parliament and of the council of 15 December 2004 relating to arsenic, cadmium, mercury, nickel and polycyclic aromatic hydrocarbons in ambient air, Off. J. Eur. Comm., L23, 26/01/2005, 3-16, 2004.

EU: Directive 2008/50/EC of the European Parliament and of the council of 21 May 2008 on ambient air quality and cleaner air for Europe, Off. J. Eur. Comm., L152,11/6/2008, 1-44, 2008.

Eyring, V., Isaksen, I., Berntsen, T., Collins, W. J., Corbett, J., Endresen, O., Grainger, R. G, Moldanova, J., Schlager, H., and Stevenson, D. S.: Transport impacts on atmosphere and climate: Shipping, Atmos. Environ., 44, 4735-4771, 2010.

Fagerli, H. and Aas, W.: Trends of nitrogen in air and precipitation: Model results and observations at EMEP sites in Europe, 19802003, Environ. Poll., 154, 448-461, 2008.

Flechard, C. R., Nemitz, E., Smith, R. I., Fowler, D., Vermeulen, A. T., Bleeker, A., Erisman, J. W., Simpson, D., Zhang, L., Tang, Y. S., and Sutton, M. A.: Dry deposition of reactive nitrogen to European ecosystems: a comparison of inferential models across the NitroEurope network, Atmos. Chem. Phys., 11, 2703-2728, doi:10.5194/acp-11-2703-2011, 2011.

Forster, P., Ramaswamy, V., Artaxo, P., Berntsen, T., Betts, R., Fahey, D. W., Haywood, J., Lean, J., Lowe, D. C., Myhre, G., Nganga, J., Prinn, R., Raga, G., Schulz, M., and Van Dorland, R.: Changes in Atmospheric Constituents and in Radiative Forcing, in: Climate Change 2007: The Physical Science Basis. Contribution of Working Group I to the Fourth Assessment Report of the Intergovernmental Panel on Climate Change, edited by: Solomon, S., Qin, D., Manning, M., Chen, Z., Marquis, M., Averyt, K. B., Tignor, M., and Miller, H. L., Cambridge, Cambridge University Press, 2007.

Fowler, D., Pilegaard, K., Sutton, M. A., Ambus, P., Raivonen, M., Duyzer, J., Simpson, D., Fagerli, H., Fuzzi, S., Schjoerring, J. K., Granier, C., Neftel, A., Isaksen, I. S. A., Laj, P., Maione, M., Monks, P. S., Burkhardt, J., Daemmgen, U., Neirynck, J., Personne, E., Wichink-Kruit, R., Butterbach-Bahl, K., Flechard, C., Tuovinen, J. P., Coyle, M., Gerosa, G., Loubet, B., Altimir, N., Gruenhage, L., Ammann, C., Cieslik, S., Paoletti, E., Mikkelsen, T. N., Ro-Poulsen, H., Cellier, P., Cape, J. N., Horvath, L., Loreto, F., Niinemets, U., Palmer, P. I., Rinne, J., Misztal, P., Nemitz, E., Nilsson, D., Pryor, S., Gallagher, M. W., Vesala, T., Skiba, U., Brueggemann, N., Zechmeister-Boltenstern, S., Williams, J., O’Dowd, C., Facchini, M. C., de Leeuw, G., Flossman, A., Chaumerliac, N., and Erisman, J. W.: Atmospheric composition change: Ecosystems-Atmosphere interactions, Atmos. Environ., 43, 5193-5267, 2009.

Furger, M., Dommen, J., Graber, W. K., Poggio, L., Prévôt, A. S. H., Emeis, S., Grell, G., Trickl, T., Gomišcek, B., Neininger, B., and Wotawa, G.: The VOTALP Mesolcina Valley Campaign 1996 concept, background and some highlights, Atmos. Environ., 34, 1395-1412, 2000. 
Gelencser, A., May, B., Simpson, D., Sanchez-Ochoa, A., Kasper-Giebl, A., Puxbaum, H., Caseiro, A., Pio, C., and Legrand, M.: Source apportionment of PM2.5 organic aerosol over Europe: Primary/secondary, natural/anthropogenic, and fossil/biogenic origin, J. Geophys. Res., 112, D23S04, doi:10.1029/2006JD008094, 2007.

Gouin, T., Harner, T., Blanchard, P., and Mackay, D.: Passive and active air samplers as complementary methods for investigating persistent organic pollutants in the Great Lakes basin, Environ. Sci. Technol., 39, 9115-9122, 2005.

Gilardoni, S., Vignati, E., Cavalli, F., Putaud, J. P., Larsen, B. R., Karl, M., Stenström, K., Genberg, J., Henne, S., and Dentener, F.: Better constraints on sources of carbonaceous aerosols using a combined ${ }^{14} \mathrm{C}$ - macro tracer analysis in a European rural background site, Atmos. Chem. Phys., 11, 5685-5700, doi:10.5194/acp-11-5685-2011, 2011.

Gilbert, R. O.: Statistical methods for environmental pollution monitoring, New York, Van Nostrand Reinhold, 1987.

Grennfelt, P. and Schjoldager, J.: Photochemical oxidants in the troposphere: a mounting menace, Ambio, 13, 61-67, 1984.

Grennfelt, P., Hoem, K., Saltbones, J., and Schjoldager, J.: Oxidant data collection in OECD Europe 1985-87 (OXIDATE): Report on ozone, nitrogen dioxide and peroxyacetyl nitrate. October 1986-March 1987, April-September 1987 and OctoberDecember 1987, Lillestrøm, Norwegian Institute for Air Research, NILU OR 63/89, 1989.

Halsall, C. J., Sweetman, A. J., Barrie, L. A., and Jones, K. C.: Modelling the behaviour of PAHs during atmospheric transport from the UK to the Arctic, Atmos. Environ., 35, 255-267, 2001.

Halse, A. K., Schlabach, M., Eckhardt, S., Sweetman, A., Jones, K. C., and Breivik, K.: Spatial variability of POPs in European background air, Atmos. Chem. Phys., 11, 1549-1564, doi:10.5194/acp-11-1549-2011, 2011.

Harmens, H., Norris, D. A., Steinnes, E., Kubin, E., Piispanen, J., Alber, R., Aleksiayenak, Y., Blum, O., Coskun, M., Dam, M., De Temmerman, L., Fernández, J. A., Frolova, M., Frontasyeva, M., González-Miqueo, L., Grodzińska, K., Jeran, Z., Korzekwa, S., Krmar, M., Kvietkus, K., Leblond, S., Liiv, S., Magnússon, S. H., Maňkovská, B., Pesch, R., Rühling, Å., Santamaria, J. M., Schröder, W., Spiric, Z., Suchara, I., Thöni, L., Urumov, V., Yurukova, L., and Zechmeister, H. G.: Mosses as biomonitors of atmospheric heavy metal deposition: Spatial patterns and temporal trends in Europe, Environ. Pollut., 158, 3144-3156, 2010.

Harner, T., Kylin, H., Bidleman, T. F., and Strachan, W. M. J.: Removal of alpha- and gamma-hexachlorocyclohexane and enantiomers of alpha-hexachlorocyclohexane in the eastern Arctic Ocean, Environ. Sci. Technol., 33, 1157-1164, 1999.

Harner, T., Bartkow, M., Holoubek, I., Klanova, J., Wania, F., Gioia, R., Moeckel, C., Sweetman, A. J., and Jones, K. C.: Passive air sampling for persistent organic pollutants: Introductory remarks to the special issue, Environ. Pollut., 144, 361-364, 2006.

Heimbürger, L.-E., Migon, C., Dufou, A., Chiffoleau, J.-F., and Cossa, D.: Trace metal concentrations in the North-western Mediterranean atmospheric aerosol between 1986 and 2008: Seasonal patterns and decadal trends, Sci. Total Environ., 408, 2629-2638, 2010.

Henne, S., Brunner, D., Folini, D., Solberg, S., Klausen, J., and Buchmann, B.: Assessment of parameters describing representativeness of air quality in-situ measurement sites, Atmos. Chem.
Phys., 10, 3561-3581, doi:10.5194/acp-10-3561-2010, 2010.

Hellsten, S., van Loon, M., Tarrason, L., Vestreng, V., Tørseth, K., Kindbom, K., and Aas, W.: Base cation deposition in Europe, Swedish Environmental Research Institute, Stockholm, IVL Report B1722, 2007.

Hjellbrekke, A.-G. and Fjæraa, A. M.: Data Report 2009, Acidifying and eutrophying compounds and particulate matter, Norwegian Institute for Air Research, Kjeller, EMEP/CCC-Report 1/2011, 2011.

Hole, J. R., Christensen, J. H., Ruoho-Airola, T., Tørseth, K., Ginzburg, V., and Glowacki, P.: Past and future trends in concentrations of sulphur and nitrogen compounds in the Arctic, Atmos. Environ., 43, 928-939, doi:10.1016/j.atmosenv.2008.10.043, 2009.

Holoubek, I., Klanova, J., Jarkovsky, J., and Kohoutek, J.: Trends in background levels of persistent organic pollutants at Kosetice observatory, Czech Republic, Part I: Ambient air and wet deposition 1996-2005, J. Environ. Monit., 9, 557-563, 2007.

HTAP: Assessment of hemispheric transport of air pollution, Part B: Mercury, edited by: Pirrone, N. and Keating, T., prepared by: the Task Force on Hemispheric Transport of Air Pollution, Economic Commission for Europe, Geneva, Air Pollution Studies No. 18, 2010.

Hung, H., Kallenborn, R., Breivik, K., Su, Y., Brorström-Lundén, E., Olafsdottir, K., Thorlacius, J. M., Leppänen, S., Bossi, R., Skov, H., Manø, S., Patton, G. W., Stern, G., Sverko, E., and Fellin, P.: Atmospheric monitoring of organic pollutants in the Arctic under the Arctic Monitoring and Assessment Programme (AMAP): 1993-2006, Sci. Total Environ., 408, 2854-2873, 2010.

Jaward, F. M., Farrar, N. J., Harner, T., Sweetman, A. J., and Jones, K. C.: Passive air sampling of PCBs, PBDEs, and organochlorine pesticides across Europe, Environ. Sci. Technol., 38, 34-41, 2004a.

Jaward, F. M., Farrar, N. J., Harner, T., Sweetman, A. J., and Jones, K. C.: Passive air sampling of polycyclic aromatic hydrocarbons and polychlorinated naphthalenes across Europe, Environ. Toxicol. Chem., 23, 1355-1364, 2004b.

Jenkin, M. E., Utembe, S. R., and Derwent, R. G.: Modelling the impact of elevated primary $\mathrm{NO}_{2}$ and $\mathrm{HONO}$ emissions on regional scale oxidant formation in the UK, Atmos. Environ., 42, 323-336, doi:10.1016/j.atmosenv.2007.09.021, 2008.

Jonson, J. E., Simpson, D., Fagerli, H., and Solberg, S.: Can we explain the trends in European ozone levels?, Atmos. Chem. Phys., 6, 51-66, doi:10.5194/acp-6-51-2006, 2006.

Kaiser, A.: Origin of polluted air masses in the Alps: An overview and first results for MONARPOP, Environ. Pollut., 157, 32323237, 2009.

Kahnert, M., Lazaridis, M., Tsyro, S., and Tørseth, K.: Requirements for developing a regional monitoring capacity for aerosols in Europe within EMEP, J. Environ. Monit., 6, 646-655, 2004.

Karlsson, P., Uddling, J., Braun, S., Broadmeadow, M., Elvira, S., Gimeno, B., Le Thiec, D., Oksanen, E., Vandermeiren, K., Wilkinson, M., and Emberson, L.: New critical levels for ozone effects on young trees based on AOT40 and simulated cumulative leaf uptake of ozone, Atmos. Environ., 38, 2283-2294, doi:10.1016/j.atmosenv.2004.01.027, 2004.

Kock, H. H., Bieber, E., Ebinghaus, R., Spain, T. G., and Thees, B.: Comparison of long-term trends and seasonal 
variations of atmospheric mercury concentrations at the two European coastal monitoring stations Mace Head, Ireland, and Zingst, Germany, Atmos. Environ., 39, 7549-7556, doi:10.1016/j.atmosenv.2005.02.059, 2005.

Konovalov, I. B., Beekmann, M., Burrows, J. P., and Richter, A.: Satellite measurement based estimates of decadal changes in European nitrogen oxides emissions, Atmos. Chem. Phys., 8, 26232641, doi:10.5194/acp-8-2623-2008, 2008.

Laj, P., Klausen, J., Bilde, M., Pla $\beta$-Duelmer, C., Pappalardo, G., Clerbaux, C., Baltensperger, U., Hjorth, J., Simpson, D., Reimann, S., Coheur, P. F., Richter, A., de Mazière, M., Rudich, Y., McFiggans, G., Tørseth, K., Wiedensohler, A., Morin, S., Schulz, M., Allan, J., Attié, J. L., Barnes, I., Birmilli, W., Cammas, P., Dommen, J., Dorn, H. P., Fuzzi, J. S., Glasius, M., Hermann, M., Kinne, S., Koren, I., Madonna, F., Maione, M., Massling, A., Moehler, O., Mona, L., Müller, D., Müller, T., Orphal, J., Peuch, W. H., Stratmann, F., Tanré, D., Tyndall, D., Riziq, A. A., Van Roozendael, M., Villani, P., Weiner, B., Wex, H., and Zardini, A.: Measuring Atmospheric Composition Change, Atmos. Environ., 43, 5351-5414, 2009.

Larsson, P.: Contaminated sediments of lakes and oceans act as sources of chlorinated hydrocarbons for release to water and atmosphere, Nature, 317, 347-349, 1985.

Lazaridis, M., Semb, A., Larssen, S., Hjellbrekke, A.-G., Hov, Ø., Hanssen, J.-E., Schaug, J., and Tørseth, K.: Measurements of particulate matter within the framework of the European Monitoring and Evaluation Programme (EMEP): I, First results, Sci. Total Environ., 285, 209-235, 2002.

Legrand, M. and Puxbaum, H.: Summary of the CARBOSOL project: present and retrospective state of organic versus inorganic aerosol over Europe, J. Geophys. Res., 112, D23S01, doi:10.1029/2006JD008271, 2007.

Li, Y. F.: Global technical hexachlorocyclohexane usage and its contamination consequences in the environment: from 1948 to 1997 , Sci. Total Environ., 232, 121-158, 1999.

Li, Y. F., Macdonald, R. W., Jantunen, L. M. M., Harner, T., Bidleman, T. F., and Strachan, W. M. J.: The transport of betahexachlorocyclohexane to the western Arctic Ocean: a contrast to alpha-HCH, Sci. Total Environ., 291, 229-246, 2002.

Loibl, W., Winiwarter, W., Kopsca, A., Zufger, J., and Baumann, R.: Estimating the spatial distribution of ozone concentrations in complex terrain, Atmos. Environ, 28, 2557-2566, doi:10.1016/1352-2310(94)90430-8, 1994.

Lorenz, M. and Granke, O.: Deposition measurements and critical loads calculations: monitoring data, results and perspective, iForest, 2, 11-14, doi:10.3832/ifor0478-002, 2009.

Lövblad, G., Tarrason, L., Tørseth, K., and Dutchak, S.: EMEP Assessment, Part I, European Perspective, Norwegian Meteorological Institute, Oslo, 2004.

Ma, J. M., Hung, H. L., Tian, C., and Kallenborn, R.: Revolatilization of persistent organic pollutants in the Arctic induced by climate change, Nat. Clim. Change, 1, 255-260, 2011.

Malanichev, A., Mantseva, E., Shatalov, V., Strukov, B., and Vulykh, N.: Numerical evaluation of the PCBs transport over the Northern Hemisphere, Environ. Pollut., 128, 279-289, 2004.

Mills, G., Hayes, F., Simpson, D., Emberson, L., Norris, D., Harmens, H., and Büker, P.: Evidence of widespread effects of ozone on crops and (semi-)natural vegetation in Europe (1990-2006) in relation to AOT40- and flux-based risk maps, Global Change Bi- ology, Blackwell Publishing Ltd, 17, 592-613, 2011.

Monks, P. S., Granier, C., Fuzzi, S., Stohl, A., Williams, M. L., Akimoto, H., Amann, M., Baklanov, A., Baltensperger, U., Bey, I., Blake, N., Blake, R. S., Carslaw, K., Cooper, O. R., Dentener, F., Fowler, D., Fragkou, E., Frost, G. J., Generoso, S., Ginoux, P., Grewe, V., Guenther, A., Hansson, H. C., Henne, S., Hjorth, J., Hofzumahaus, A., Huntrieser, H., Isaksen, I. S. A., Jenkin, M. E., Kaiser, J., Kanakidou, M., Klimont, Z., Kulmala, M., Laj, P., Lawrence, M. G., Lee, J. D., Liousse, C., Maione, M., McFiggans, G., Metzger, A., Mieville, A., Moussiopoulos, N., Orlando, J. J., O'Dowd, C. D., Palmer, P. I., Parrish, D. D., Petzold, A., Platt, U., Pöschl, U., Prévôt, A. S. H., Reeves, C. E., Reimann, S., Rudich, Y., Sellegri, K., Steinbrecher, R., Simpson, D., ten Brink, H., Theloke, J., van der Werf, G. R., Vautard, R., Vestreng, V., Vlachokostas, Ch., and von Glasow, R.: Atmospheric composition change - global and regional air quality, Atmos. Environ., 43, 5268-5350, 2009.

Monteiro, A. Carvalho, A., Ribeiro, I., Scotto, M., Barbosa, S., Alonso, A., Baldasano, J. M., Pay, M. T., Miranda, A. I., and Borrego, C.: Trends in ozone concentrations in the Iberian peninsula by Quantile regression and clustering, Atmos. Environ., 56, 184-193, doi:10.1016/j.atmosenv.2012.03.069, 2012.

Munthe, J., Wangberg, I., Iverfeldt, A., Lindqvist, O., Stromberg, D., Sommar, J., Gardfeldt, K., Petersen, G., Ebinghaus, R., Prestbo, E., Larjava, K., and Siemens, V.: Distribution of atmospheric mercury species in Northern Europe: final results from the MOE project, Atmos. Environ., 37, 9-20, 2003.

Nizzetto, L., Macleod, M., Borga, K., Cabrerizo, A., Dachs, J., Di Guardo, A., Ghirardello, D., Hansen, K. M., Jarvis, A., Lindroth, A., Ludwig, B., Monteith, D., Perlinger, J. A., Scheringer, M., Schwendenmann, L., Semple, K. T., Wick, L. Y., Zhang, G., and Jones, K. C.: Past, present, and future controls on levels of persistent organic pollutants in the global environment, Environ. Sci. Technol., 44, 6526-6531, 2010.

Ockenden, W. A., Steinnes, E., Parker, C., and Jones, K. C.: Observations on persistent organic pollutants in plants: Implications for their use as passive air samplers and for POP cycling, Environ. Sci. Technol., 32, 2721-2726, 1998.

OECD: The OECD Programme on Long Range Transport of Air Pollutants. Measurements and Findings. Organisation for Economic Co-operation and Development, Paris 1977, Report can be downloaded from http://www.nilu.no/projects/ccc/reports/paris 1977.pdf, 1977.

Odèn, S.: Nederbördens og luftens försurning, dess orsaker, förlopp och verkan i olika miljöer. Statens naturvetenskapliga forskningsråd, Stockholm, Ecologikommitèen Bull. No. 1, 1968.

Oltmans, S. J., Lefohn, A. S., Harris, J. M., Galbally, I., Scheel, H. E., Bodeker, G., Brunke, E., Claude, H., Tarasick, D., Johnson, B. J., Simmonds, P., Shadwick, D., Anlauf, K., Hayden, K., Sch midlin, F., Fujimoto, T., Akagi, K., Meyer, C., Nichol, S., Davies, J., Redondas, A., and Cuevas, E.: Long-term changes in tropospheric ozone, Atmos. Environ., 40, 3156-3173, doi:10.1016/j.atmosenv.2006.01.029, 2006.

Ordóñez, C., Mathis, H., Furger, M., Henne, S., Hüglin, C., Staehelin, J., and Prévôt, A. S. H.: Changes of daily surface ozone maxima in Switzerland in all seasons from 1992 to 2002 and discussion of summer 2003, Atmos. Chem. Phys., 5, 1187-1203, doi:10.5194/acp-5-1187-2005, 2005. 
Ottar, B.: The transfer of airborne pollutants to the Arctic region, Atmos. Environ., 15, 1439-1445, 1981.

Ottar, B., Dovland, H., and Semb, A.: Long range transport of air pollutants and acid precipitation, Air Pollution and Plant Life, edited by: Treshov, M. Wiley, 39-71, 1984.

Pacyna, J. M., Semb, A., and Hanssen, J. E.: Emission and longrange transport of trace elements in Europe, Tellus, 36b, 163178, 1984.

Pacyna, E. G., Pacyna, J. M., Fudala, J., Strzelecka-Jastrzab, E., Hlawiczka, S., Panasiuk, D., Nitter, S., Pregger, T., Pfeiffer, H., and Friedrich, R.: Current and future emissions of selected heavy metals to the atmosphere from anthropogenic sources in Europe, Atmos. Environ., 41, 8557-8566, 2007.

Pacyna, J. M., Pacyna, E. G., and Aas, W.: Changes of emissions and atmospheric deposition of mercury, lead, and cadmium, Atmos. Environ., 43, 117-127, 2009.

Perrino, C., Canepari, S., Catrambone, M., Dalla Torre, S., Rantica, E., and Sargolini, T.: Influence of natural events on the concentration and composition of atmospheric particulate matter, Atmos. Environ., 43, 4754-4765, 2008.

Philippin, S., Laj, P., Putaud, J.-P., Wiedensohler, A., de Leeuw, G., Fjaeraa, A. M., Platt, U., Baltensperger, U., and Fiebig, M.: EUSAAR - An Unprecedented Network of Aerosol Observation in Europe, Earozoru Kenkyu, 24, 78-83, 2009.

Pio, C. A., Legrand, M., Oliveira, T., Afonso, J., Santos, C., Caseiro, A., Fialho, P., Barata, F., Puxbaum, H., Sanchez-Ochoa, A., Kasper-Giebl, A., Gelencsér, A., Preunkert, S., and Schock, M.: Climatology of aerosol composition (organic versus inorganic) at non-urban areas on a west-east transect across Europe, J. Geophys. Res., 112, D23S02, doi:10.1029/2006JD008038, 2007.

Pozo, K., Harner, T., Lee, S. C., Wania, F., Muir, D. C. G., and Jones, K. C.: Seasonally resolved concentrations of persistent organic pollutants in the global atmosphere from the first year of the GAPS study, Environ. Sci. Technol., 43, 796-803, 2009.

Putaud, J.-P., Van Dingenen, R., Alastuey, A., Bauer, H., Birmili, W., Cyrys, J., Flentje, H., Fuzzi, S., Gehrig, R., Hansson, H. C., Harrison, R. M., Herrmann, H., Hitzenberger, R., Hüglin, C., Jones, A. M., Kasper-Giebl, A., Kiss, G., Kousa, A., Kuhlbusch, T. A. J., Löschau, G., Maenhaut, W., Molnar, A., Moreno, T., Pekkanen, J., Perrino, C., Pitz, M., Puxbaum, H., Querol, X., Rodriguez, S., Salma, I., Schwarz, J., Smolik, J., Schneider, J., Spindler, G., ten Brink, H., Tursic, J., Viana, M., Wiedensohler, A., and Raes, F.: A European aerosol phenomenology - 3: Physical and chemical characteristics of particulate matter from 60 rural, urban, and kerbside sites across Europe, Atmos. Environ., 44, 1308-1320, 2010.

Querol, X., Alastuey, A., Pey, J., Cusack, M., Pérez, N., Mihalopoulos, N., Theodosi, C., Gerasopoulos, E., Kubilay, N., and Koçak, M.: Variability in regional background aerosols within the Mediterranean, Atmos. Chem. Phys., 9, 4575-4591, doi:10.5194/acp-9-4575-2009, 2009.

Rodhe, H. and Granat, L.: An evaluation of sulfate in European precipitation 1955-1982, Atmos. Environ., 18, 2627-2639, doi:10.1016/0004-6981(84)90327-5, 1984.

Ruzickova, P., Klanova, J., Cupr, P., Lammel, G., and Holoubek, I.: An assessment of air-soil exchange of polychlorinated biphenyls and organochlorine pesticides across Central and Southern Europe, Environ. Sci. Technol., 42, 179-185, 2008.
Salmi, T., Määttä, A., Anttila, P., Ruoho-Airola, T., and Amnell, T.: Detecting trends of annual values of atmospheric pollutants by the Mann-Kendall test and Sen's slope estimates - the Excel template application MAKESENS, Helsinki, Finnish Meteorological Institute, Report code FMI-AQ-31, 2002.

Schaap, M., Otjes, R. P., and Weijers, E. P.: Illustrating the benefit of using hourly monitoring data on secondary inorganic aerosol and its precursors for model evaluation, Atmos. Chem. Phys., 11, 11041-11053, doi:10.5194/acp-11-11041-2011, 2011.

Scheel, H., Areskoug, H., Geiss, H., Gomiscek, B., Granby, K., Haszpra, L., Klasinc, L., Kley, D., Laurila, T., Lindskog, A., Roemer, M., Schmitt, R., Simmonds, P., Solberg, S., and Toupance, G.: On the spatial distribution and seasonal variation of lowertroposphere ozone over Europe, J. Atmos. Chem., 28, 11-28, 1997.

Schlabach, M., Aas, W., Hung, H. M., Rania, F., and Su, Y.: NCP, AMAP and EMEP POP laboratory comparison 2010, Kjeller, Norwegian Institute for Air Research, EMEP/CCCReport 7/2011, 2011.

Schuster, J. K., Gioia, R., Sweetman, A. J., and Jones, K. C.: Temporal trends and controlling factors for polychlorinated biphenyls in the UK atmosphere (1991-2008), Environ. Sci. Technol., 44, 8068-8074, 2010.

Schuster, J. K., Gioia, R., Breivik, K., Steinnes, E., Scheringer, M., and Jones, K. C.: Trends in European background air reflect reductions in primary emissions of PCBs and PBDEs, Environ. Sci. Technol., 44, 6760-6766, 2011.

Semb, A.: Sulphur emissions in Europe, Atmos. Environ., 12, 455460, 1978.

Shoeib, M. and Harner, T.: Characterization and comparison of three passive air samplers for persistent organic pollutants, Environ. Sci. Technol., 36, 4142-4151, 2002.

Simpson, D., Olendrzynski, K., Semb, A., Støren, E., and Unger, S.: Photochemical oxidant modelling in Europe: multi-annual modelling and source-receptor relationships, Oslo, The Norwegian Meteorological Institute, EMEP/MSC-W Report 3/97, 1997.

Simpson, D., Yttri, K., Klimont, Z., Kupiainen, K., Caseiro, A., Gelencsér, A., Pio, C., and Legrand, M.: Modeling carbonaceous aerosol over Europe. analysis of the CARBOSOL and EMEP EC/OC campaigns, J. Geophys. Res., 112, D23S14, doi:10.1029/2006JD008158, 2007a.

Simpson, D., Emberson, L., Ashmore, M., and Tuovinen, J.: A comparison of two different approaches for mapping potential ozone damage to vegetation. A model study, Environ. Pollut., 146, 715725, doi:10.1016/j.envpol.2006.04.013, 2007b.

Simpson, D., Benedictow, A., Berge, H., Bergström, R., Emberson, L. D., Fagerli, H., Hayman, G. D., Gauss, M., Jonson, J. E., Jenkin, M. E., Nyíri, A., Richter, C., Semeena, V. S., Tsyro, S., Tuovinen, J.-P., Valdebenito, Á., and Wind, P.: The EMEP MSCW chemical transport model - Part 1: Model description, Atmos. Chem. Phys. Discuss., 12, 3781-3874, doi:10.5194/acpd12-3781-2012, 2012.

Skiba, U., Drewer, J., Tang, Y. S., van Dijk, N., Helfter, C., Nemitz, E., Famulari, D., Cape, J. N., Jones, S. K., Twigg, M., Pihlatie, M., Vesala, T., Larsen, K. S., Carter, M. S., Ambus, P., Ibrom, A., Beier, C., Hensen, A., Frumau, A., Erisman, J. W., Brüggemann, N., Gasche, R., Butterbach-Bahl, K., Neftel, A., Spirig, C., Horvath, L., Freibauer, A., Cellier, P., Laville, P., Loubet, B., Magliulo, E., Bertolini, T., Seufert, G., Andersson, M., Manca, G., 
Laurila, T., Aurela, M., Lohila, A., Zechmeister-Boltenstern, S., Kitzler, B., Schaufler, G., Siemens, J., Kindler, R., Flechard, C., and Sutton, M. A.: Biosphere-atmosphere exchange of reactive nitrogen and greenhouse gases at the NitroEurope core flux measurement sites: Measurement strategy and first data sets, Agric. Ecosyst. Environ., 133, 139-149, 2009.

Skjelkvåle, B. L., Stoddard, J. L., Jeffries, D. S., Tørseth, K., Høgåsen, T., Bowman, J., Mannio, J., Monteith, D. T., Mosello, R. Rogora, M., Rzychon, D., Vesely, J., Wieting, J., Wilander A., and Worsztynowicz, A.: Regional scale evidence for improvements in surface water chemistry 1990-2001, Environ. Pollut., 137, 165-176, 2005.

Slemr, F. and Scheel, H. E.: Trends in atmospheric mercury concentrations at the summit of the Wank Mountain, Southern Germany, Atmos. Environ., 32, 845-853, 1998.

Slootweg, J., Posch, M., and Hettelingh, J. P. (Eds.): Progress in the modelling of critical thresholds, impacts to plant species diversity and ecosystem services in Europe, CCE Status Report 2010, PBL Netherlands Environmental Assessment Agency, Coordination Centre for Effects, Bilthoven, 2010.

Smidt, S., Spangl, W., and Nagl, C.: Trends of air pollutant input in Austrian forest areas, Austr. J. For. Sci., 127, 1-24, 2010.

Solberg, S.: VOC measurements 2009, Kjeller, Norwegian Institute of Air Research, EMEP/CCC-Report 6/2011, 2011.

Solberg, S., Dye, C., Walker, S.-E., and Simpson, D.: Long-term measurements and model calculations of formaldehyde at rural European monitoring sites, Atmos. Environ., 35, 195-207, 2001.

Solberg, S., Bergstrøm, R., Langner, J., Laurila, T., and Lindskog, A.: Changes in Nordic surface ozone episodes due to European emission reductions in the 1990s, Atmos. Environ., 39, 179-192, 2005.

Strode, S. A., Jaeglé, L., Selin, N. E., Jacob, D. J., Park, R. J., Yantosca, R. M., Mason, R. P., and Slemr, F.: Air-sea exchange in the global mercury cycle, Global Biogeochem. Cycles, 21, GB1017, doi:10.1029/2006GB002766, 2007.

Su, Y. S. and Hung, H. L: Inter-laboratory comparison study on measuring semi-volatile organic chemicals in standards and air samples, Environ. Pollut., 158, 3365-3371, 2010.

Sutton, M. S., Howard, C.-M., Erisman, J. W. Billen, G., Bleeker A., Grennfelt,P., van Grinsven, H., and Grizzetti, B. (Eds.): The European nitrogen assessment - sources, effects and policy perspectives, Cambridge Univ. Press, Cambridge, 2011.

Travnikov, O., Gusev, A., Ilyin, I., Shatalov, V., and Sokovyh, V.: Global EMEP Multi-media Modelling System (GLEMOS): Application to heavy metal and POP pollution, in preparation, 2012.

Tørseth, K. (Ed.): ACCENT workshop on network harmonization and data intercomparability 28-30 January 2008, Las Vegas, USA, ACCENT, Report 2.08, http://www4.nilu.no/farcry_accent/download.cfm? DownloadFile30AB6844-17A4-8DB2-8C461AE65F2545B1, 2008.

Tørseth, K. and Hov, Ø. (Eds.): The EMEP monitoring strategy 2004-2009. Background document with justification and specification of the EMEP monitoring programme, 2004-2009, EMEP/CCC-Report 9/2003, 69 pp., NILU, Kjeller, 2003.

Uggerud, H. Th. and Hjellbrekke, A.-G.: The twenty-seventh and twenty-eighth intercomparison of analytical methods within EMEP, Kjeller, Norwegian Institute for Air Research, EMEP/CCC-Report 5/2011, 2011a.
Uggerud, H. Th. and Hjellbrekke, A.-G.: Analytical intercomparison of heavy metals in precipitation 2009 and 2010, Kjeller, Norwegian Institute for Air Research, EMEP/CCC-Report 4/2011, 2011b.

UNECE: Handbook for the 1979 Convention on Long-Range Transboundary Air Pollution and its Protocols, Geneva, United Nations Economic Commissions for Europe, ECE/EB.AIR/85, 2004a.

UNECE: Clearing the Air - 25 years of the Convention on Longrange Transboundary Air Pollution, Geneva, United Nations Economic Commissions for Europe, ECE/EB.AIR/84, $2004 \mathrm{~b}$.

UNECE: EMEP monitoring strategy for 2010-1010, United Nations Economic Commissions for Europe, Geneva, ECE/EB.AIR/GE.1/2009/15, http://www.unece.org/env/ documents/2009/EB/ge1/ece.eb.air.ge.1.2009.15.e.pdf, 2009.

UNEP Chemical Branch: The global atmospheric mercury assessment: Sources, emissions and transport. Geneva, United Nations Environment Program Chemical Branch, http://www.chem.unep.ch/mercury/Atmospheric_Emissions/ Atmospheric_emissions_mercury.htm, 2008.

UNEP/DEWA: Integrated assessment of black carbon and tropospheric ozone; Summary for decision makers, United Nations Environment Programme, Division of Early Warning and Assessment, Nairobi, 2011.

Vautard, R., Szopa, S., Beekmann, M., Menut, L., Hauglustaine, D. A., Rouil, L., and Roemer, M.: Are decadal anthropogenic emission reductions in Europe consistent with surface ozone observations?, Geophys. Res. Lett., 33, L13810, doi:10.1029/2006GL026080, 2006.

Vestreng, V., Myhre, G., Fagerli, H., Reis, S., and Tarrasón, L.: Twenty-five years of continuous sulphur dioxide emission reduction in Europe, Atmos. Chem. Phys., 7, 3663-3681, doi:10.5194/acp-7-3663-2007, 2007.

Vestreng, V., Ntziachristos, L., Semb, A., Reis, S., Isaksen, I. S. A., and Tarrasón, L.: Evolution of $\mathrm{NO}_{\mathrm{x}}$ emissions in Europe with focus on road transport control measures, Atmos. Chem. Phys., 9, 1503-1520, doi:10.5194/acp-9-1503-2009, 2009.

Vijgen, J., Abhilash, P. C., Li, Y.F., Lal, R., Forter, M., Torres, J., Singh, N., Yunus, M., Tian, C., Schäffer, A., and Weber, R.: Hexachlorocyclohexane $(\mathrm{HCH})$ as new Stockholm Convention POPs-a global perspective on the management of Lindane and its waste isomers, Environ. Sci. Pollut. Res., 18, 152-162, 2011.

Wangberg, I., Munthe, J., Ebinghaus, R., Gardfeldt, K., and Sommar, J.: Distribution of TPM in Northern Europe, Sci. Total Environ., 304, 53-59, 2003.

Wängberg, I., Munthe, J., Berg, T., Ebinghaus, R., Kock, H. H., Temme, C., Bieber, E., Spain, T. G., and Stolk, A.: Trends in air concentration and deposition of mercury in the coastal environment of the North Sea, Atmos. Environ., 41, 2612-2619, 2007.

Wania, F.: On the origin of elevated levels of persistent chemicals in the environment, Environ. Sci. Pollut. Res., 6, 11-19, 1999.

Wania, F. and Haugen, J. E.: Long term measurements of wet deposition and precipitation scavenging of hexachlorocyclohexanes in Southern Norway, Environ. Pollut., 105, 381-386, 1999.

Wania, F. and Mackay, D.: Global fractionation and cold condensation of low volatility organochlorine compounds in polar regions, Ambio, 22, 10-18, 1993.

Wania, F. and Mackay, D.: Tracking the distribution of persistent organic pollutants, Environ. Sci. Technol., 30, A390-A396, 1996. 
WGE: 30 years of effects research, monitoring and modelling under the Convention on Long-range Transboundary Air Pollution Working Group on Effects, Federal Environment Agency (UBA), Dessau, Germany, 2011.

WHO: The World Health Report 2002: Reducing risks, promoting healthy life, Geneva, World Health Organization, 2002.

WHO: Air quality guidelines for particulate matter, ozone, nitrogen dioxide and sulfur dioxide - Global update 2005, Copenhagen, World Health Organization, http://www.who.int/ phe/health_topics/outdoorair_aqg/en/ [2011-08-16], 2005.

WMO operations manual for sampling and analysis techniques for chemical constituents in air and precipitation, World Meteorological Organization, Geneva, 1974.

Wilson, R. C., Fleming, Z. L., Monks, P. S., Clain, G., Henne, S., Konovalov, I. B., Szopa, S., and Menut, L.: Have primary emission reduction measures reduced ozone across Europe? An analysis of European rural background ozone trends 1996-2005, Atmos. Chem. Phys., 12, 437-454, doi:10.5194/acp-12-437-2012, 2012.

Winkler, P. and Roider, G.: HELCOM - EMEP - PARCOM AMAP: Field intercomparison of heavy metals in precipitation 1995, Hohenpeissenberg, Deutscher Wetterdienst, Meteorologisches Observatorium, Report nr UBA-FB-98-059/e, 1997.

Xiao, H., Li, N. Q., and Wania, F.: Compilation, evaluation, and selection of physical-chemical property data for alpha-, beta-, and gamma-hexachlorocyclohexane, J. Chem. Eng. Data, 49, 173$185,2004$.
Yttri, K. E., Aas, W., Bjerke, A., Cape, J. N., Cavalli, F., Ceburnis, D., Dye, C., Emblico, L., Facchini, M. C., Forster, C., Hanssen, J. E., Hansson, H. C., Jennings, S. G., Maenhaut, W., Putaud, J. P., and Tørseth, K.: Elemental and organic carbon in $\mathrm{PM}_{10}$ : a one year measurement campaign within the European Monitoring and Evaluation Programme EMEP, Atmos. Chem. Phys., 7, 5711-5725, doi:10.5194/acp-7-5711-2007, 2007.

Yttri, K. E., Simpson, D., Nøjgaard, J. K., Kristensen, K., Genberg, J., Stenström, K., Swietlicki, E., Hillamo, R., Aurela, M., Bauer, H., Offenberg, J. H., Jaoui, M., Dye, C., Eckhardt, S., Burkhart, J. F., Stohl, A., and Glasius, M.: Source apportionment of the summer time carbonaceous aerosol at Nordic rural background sites, Atmos. Chem. Phys., 11, 13339-13357, doi:10.5194/acp11-13339-2011, 2011a.

Yttri, K. E., Simpson, D., Stenström, K., Puxbaum, H., and Svendby, T.: Source apportionment of the carbonaceous aerosol in Norway - quantitative estimates based on ${ }^{14} \mathrm{C}$, thermal-optical and organic tracer analysis, Atmos. Chem. Phys., 11, 9375-9394, doi:10.5194/acp-11-9375-2011, $2011 \mathrm{~b}$.

Zhang, Y. and Tao, S.: Global atmospheric emission inventory of polycyclic aromatic hydrocarbons (PAHs) for 2004, Atmos. Environ., 43, 812-819, 2009. 